\title{
AN ASSESSMENT OF RADIOCARBON DATES FROM PALAU, WESTERN MICRONESIA
}

\author{
Jolie Liston \\ International Archaeological Research Institute, Inc., 2081 Young Street, Honolulu, Hawaii 96826, USA. \\ Email: jliston@iarii.org.
}

\begin{abstract}
Archaeological investigations in the Republic of Palau, Micronesia, have produced 409 radiocarbon age determinations from cultural contexts, indicating a range of Palauan occupation from about 3000 yr ago into the modern era. However, these dates are scattered among numerous sources (many difficult to obtain) and are presented in a number of different formats and calibrations. The goal of this paper is to compile a usable, systematic database of all of these Palauan cultural ${ }^{14} \mathrm{C}$ assays. This database will be suitable for developing and evaluating chronological models, an effort being undertaken as a separate paper. Prior to constructing prehistoric colonization and cultural chronologies for Palau, the validity of each assay and the relative adequacy in sample size per cultural and environmental zones must be examined. After systematic recalibration, the reliability of the dates is evaluated in light of sample material, cultural context, and site formation processes. A method for dating monumental earthwork complexes through site formation analysis is presented. Sets of 237 valid and 58 potentially valid ${ }^{14} \mathrm{C}$ dates remain to develop chronological models. The representation of Palau's environmental zones, site types, and regions within the dating pool is examined and compared to ensure meaningfulness in these chronological models. Newly obtained ${ }^{14} \mathrm{C}$ age determinations are also provided.
\end{abstract}

\section{INTRODUCTION}

The Republic of Palau is an archipelago of some 350 islands scattered along a 150-km north-south arc in the Western Carolines of Micronesia (Figure 1). Babeldaob is the largest of the islands; its $331 \mathrm{~km}^{2}$ comprise $80 \%$ of Palau's landmass. Volcanic in origin, Babeldaob has a heavily weathered central mountain system that reaches a maximum elevation of $242 \mathrm{~m}$ asl with steep-sided valleys and associated ridges. Low, rolling hills circle the base of the uplands, while in limited places beaches form thin strips of bottomlands. Thick mangrove forests encircle much of the island. Small uplifted coralline islands, referred to locally as the Rock Islands, stretch about $30 \mathrm{~km}$ from the south tip of Babeldaob to the low platform island of Peleliu. Composed of generally steeply sloped, bowed ridges reaching elevations up to $200 \mathrm{~m}$ asl, these islands have long, rocky shorelines, numerous limestone caves and solution notches, but relatively few beach deposits. Ten $\mathrm{km}$ southeast of Peleliu is the low platform island of Angaur, while about $600 \mathrm{~km}$ southwest are the moderately uplifted reef flats and atoll composing the Southwest Islands. ${ }^{1}$ Kayangel and Ngeruangel, two classic coral atolls, are about $30 \mathrm{~km}$ to the north of Babeldaob. A wide, shallow lagoon separates Babeldaob, the Rock Islands, and Peleliu from the surrounding fringing and barrier reefs.

Recent archaeological investigations in Palau have increased dramatically the number of radiocarbon age determinations to over 400, the largest suite of dates in Micronesia except for Guam. These ${ }^{14} \mathrm{C}$ assays, particularly those that push human occupation of Palau to over a millennia earlier than previously thought, provide substantial fodder for debates on the timing and origin of initial settlement and patterns of cultural development in the west Pacific (Athens and Ward 2001; Clark and Wright 2003; Fitzpatrick 2003; Clark, forthcoming). Discussions of Palau's role in the Austronesian expansion from island Southeast Asia into the Pacific and construction of a prehistoric cultural chronology must rely on a standardized, reliable, and complete suite of ${ }^{14} \mathrm{C}$ assays.

Palau's ${ }^{14} \mathrm{C}$ age determinations were first standardized and assessed by Masse in $1984(1984,1989$, 1990). Most of his 81 dates were from sites in the Rock Islands, presenting a limited view of Palauan

${ }^{1}$ The Southwest Islands-Sonsorol, Fana, Pulo Anna, Merir, Tobi, and Helen Reef-have a combined landmass of about $6 \mathrm{~km}^{2}$. 

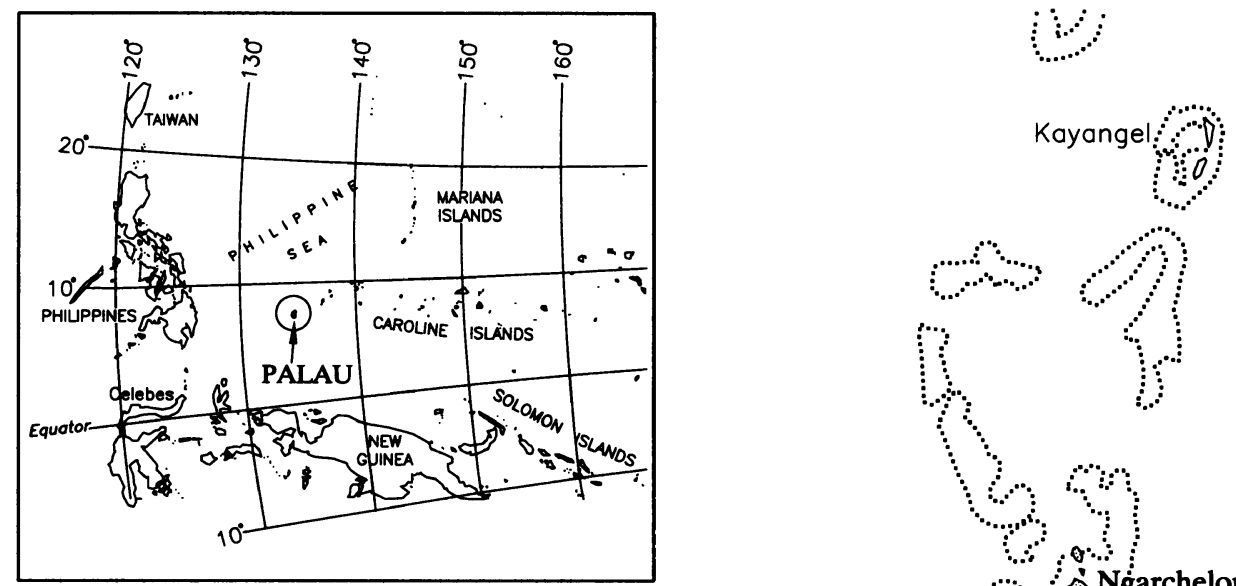

PALAU
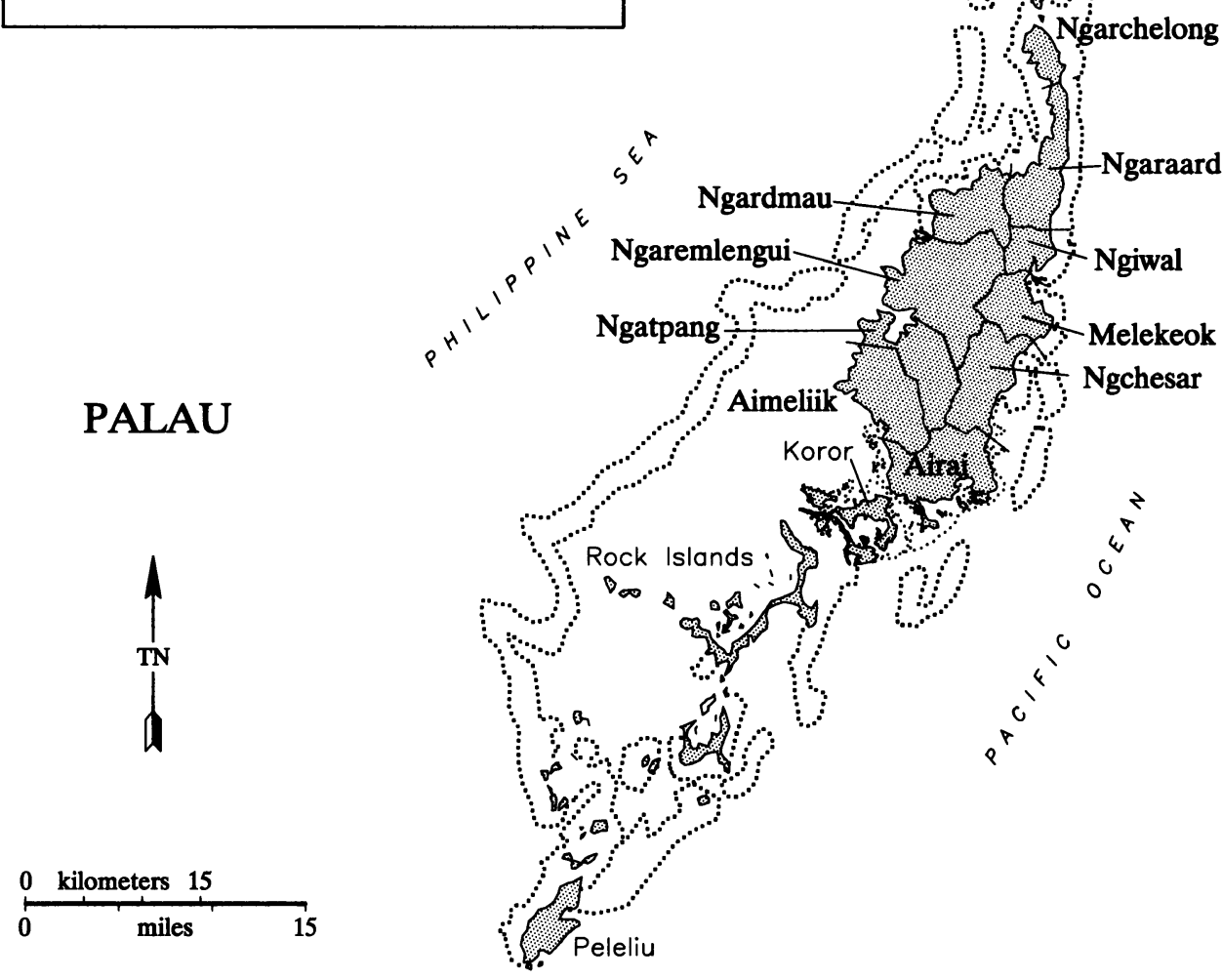

Wangaur

Figure 1 Map of the Republic of Palau

prehistory. The subsequent escalation in the number of ${ }^{14} \mathrm{C}$ dates is a result of compliance by various development projects with historic preservation statutes ${ }^{2}$ (e.g. Beardsley 1997; Wickler et al. 1998;

\footnotetext{
${ }^{2}$ This is largely due to cultural resource management studies conducted by International Archaeological Research Institute, Inc. (IARII), in support of the US Army Corps of Engineers-designed Palau Compact Road, an 85-km road circling Babeldaob.
} 
Liston 1999) and academically sponsored research (Fitzpatrick 2002; Clark and Wright 2002; Phear 2004). The $409{ }^{14} \mathrm{C}$ dates from cultural contexts are derived from wood charcoal $(n=266)$, marine shell $(n=99)$, pottery $(n=21)$, bone $(n=16)$, pottery residue $(n=6)$, and a sponge spicule, and provide the baseline data for constructing chronological models of Palau's colonization and prehistoric settlement pattern and elucidating temporal changes to subsistence practices and social organization. Recently, Phear et al. (2003) reviewed some of these ${ }^{14} \mathrm{C}$ determinations and constructed such a model.

This paper aims to present, standardize, and assess the validity of this suite of ${ }^{14} \mathrm{C}$ dates, then determine the meaningfulness of the resulting data set in constructing Palauan colonization and cultural chronologies. Evaluating the reliability of the ${ }^{14} \mathrm{C}$ assays is a multifold process that takes into account suitability of sample material, collecting and processing protocols, and cultural context (Anderson 1991; Spriggs and Anderson 1993). Not isolated from these difficulties are the geographic variables, climatic conditions, and archaeological site types that generate complex site formation processes. To accurately assess the corpus of dates, conditions specific to Palau must be factored in. The meaningfulness of a suite of dates in constructing models is dependent on an adequate sample size from each of Palau's environmental zones, site types, and regions. Construction of a prehistoric Palauan cultural chronology is not the task of this paper; rather, the goal is to provide a complete, standardized, and valid database of ${ }^{14} \mathrm{C}$ assays to use in developing such models.

\section{METHODS}

The 409 Palauan ${ }^{14} \mathrm{C}$ dates that are associated with archaeological materials were compiled from cultural resource management reports, theses, and journal articles. They are summarized in Appendices A, B, and C. The primary resource base was supplied by excavation reports and field notes containing comprehensive excavation details, sample context, and methodologies employed. ${ }^{3}$

In addition to the 409 cultural ${ }^{14} \mathrm{C}$ dates, there are 62 assays from paleoenvironmental cores (HunterAnderson 1992; Athens and Ward 2002, 2005) and 2 from sediment samples (Hunter-Anderson 1992). These are presented in Appendix D in order to provide a comprehensive list of Palauan ${ }^{14} \mathrm{C}$ date ranges, but these are not reviewed in the present paper because dates from these contexts require evaluation based on a different set of assumptions, methods, and interpretations than those used in the investigations of cultural contexts, and this is beyond the scope of this paper.

Masse's $(1984,1989)$ adjustments to Palau's first 81 assays were not retained due to uncertainties regarding his $\Delta \mathrm{R}$ value of -63 (W B Masse, personal communication, 2005). The samples were standardized by recalibrating them to $2 \sigma$ with the IntCal98 and MARINE98 calibration curve (Stuiver et al. 1998) using OxCal v 3.9 (Ramsey 2003). No $\Delta \mathrm{R}$ value was applied to the marine shell and fish bone samples. Human bone samples were calibrated using a mixed calibration curve of $70 \%$ marine and $30 \%$ terrestrial components. The calendrical age range is provided rather than the median calibrated date due to the multimodality of the calibration curve.

The dates are assessed for their utility in building Palauan cultural chronologies. Though useful information might be garnered from all 409 dates, only those that can meaningfully contribute to these models are retained in the evaluation. Each assay is evaluated on a case-by-case basis, with the criteria listed below used as a guideline in the assessment. Elaboration on some of the points is presented in the manuscript. Seldom is one factor sufficient in itself to unequivocally support classifi-

${ }^{3}$ Excavation reports are available at the Palau Bureau of Arts and Culture and from archaeological contract firms. 
cation of a date, but with corroborating evidence from a number of criteria their credibility, or lack of, is established. ${ }^{4}$ As identifying the origin of stratigraphic units and the relationship of associated cultural material is essential to the assessment, site formation analysis is integrated into many of the criteria. Results, with the ${ }^{14} \mathrm{C}$ date ranges categorized as eliminated $(n=114,28 \%)$, possible $(n=58$, $15 \%)$, or accepted $(n=237,57 \%)$, are given in Appendices A, B, and C, organized by laboratory number.

\section{Criteria for Elimination from the Database:}

A. Assays that obviously pre-date colonization of Palau and modern dates are discarded as irrelevant to constructing prehistoric and early historic Palauan chronologies. Timing of colonization is not firmly established, but it is highly improbable that the archipelago was occupied before $4000 \mathrm{BC}$;

B. Assays justifiably dismissed by the excavator (e.g. lab errors or statistical outliers);

C. Assays with a 2- $\sigma$ range of 900 yr are rejected due to their limited usefulness when working in a time depth of less than half a millennium;

D. Stratigraphically inverted dates that are not interpretable by site formation analysis and cannot be meaningfully applied in a cultural chronology;

E. Assays with an unclear or nonexistent cultural association (e.g. not clearly or directly associated with contemporaneous artifactual material) that cannot be meaningfully used to interpret anthropogenic site formation;

F. Assays from dispersed charcoal samples, unless originating in a discrete feature or accompanied by other mitigating circumstances;

G. Assays that do not corroborate with others in a feature, deposit, or site (unless the site is shown to contain several cultural horizons);

H. Assays from disturbed contexts - crab burrowing, gardening, World War II activities, deposits subject to tidal inflows or storm waves, or early assays associated with recent historic artifacts (unless sample is charcoal identified as non-endemic to ecological setting);

I. Problems with age determinations on sample material (e.g. pottery).

\section{Criterion for Classification as Possible Cultural Date:}

J. Dates that cannot be adequately assessed due to inadequate field data or language barriers, or problematical assays that are potentially credible. Individual assays that are potentially postbomb.

\section{Criteria for Acceptance:}

$\mathrm{K}$. A series in stratigraphic order;

L. Corroboration with a different fraction of the same sample or with a different sample from the same feature, cultural stratum, or small-scale site;

M. Assays on wood taxa identified as non-endemic to ecological setting (e.g. coconut or mangrove species on ridge and hill tops);

N. Assays on identified charcoal of short-lived taxa in a discrete subfeature, or assays from a discrete subfeature;

O. Assays suitable for interpretation in site formation analysis only (e.g. a sample of anthropogenic origin in terrace fill or erosion).

\footnotetext{
${ }^{4}$ It is unfeasible to provide a strict set of decisive factors that can both operate in isolation and be applied to every situation. Tacked on to each criterion should be "unless accompanied by other mitigating circumstances." It is of fundamental importance to know and understand the nature of Palauan site types and their deposits in order to evaluate the dates with combinations of criteria.
} 


\section{SAMPLE MATERIAL}

Intensive weathering of Babeldaob's basalt-andesite breccias has resulted in the formation of clayey soils, over $70 \%$ of which are lateritic. These acidic latosols are not conducive to the preservation of perishable items such as bone, shell, and uncarbonized wood, and the latosols treat ceramics harshly. According to Pregill and Steadman (2000:138), the "scarcity of rich, fossiliferous sediment in Palau is thus far unequalled for tropical Pacific islands." Thus, datable material other than charcoal is rare on Babeldaob, limited primarily to beach deposits, caves, or some densely packed depositional conditions. In the limestone Rock Islands, preservation of a variety of datable materials is generally far superior to that of Babeldaob.

\section{Shell}

Marine shell is the source of $99{ }^{14} \mathrm{C}$ determinations, $75 \%$ of which are from Rock Island sites. As marine shell is naturally abundant on Palau's shorelines and is easily redeposited by tidal movements and storm waves, a secure cultural context must be established before a shellfish date becomes meaningful.

A primary obstacle to using shellfish as a dating source is the lack of a localized correction factor for the marine reservoir effect. $\Delta R$ values ranging from zero (Fitzpatrick 2002; Clark 2004) to $115 \pm 50$ (Beardsley 1996, 1997) have been applied to Palauan shellfish samples. Masse $(1984,1989)$ employed a "tentative" $\Delta R$ value of $-63 \pm 4$ after considering associated charcoal/shell assays, surface equatorial seawater ${ }^{14} \mathrm{C}$ transects, and a chronological gap between stonework villages on the Rock Islands and Babeldaob. $\Delta \mathrm{R}$ correction factors from regions relatively near Palau are close to the global ocean's apparent age of approximately $400{ }^{14} \mathrm{C}$ yr. Three marine shell samples from the Philippines have produced $\Delta \mathrm{R}$ values of $89 \pm 70,-41 \pm 70$, and $-61 \pm 50$; one value from Nauru Island is $6 \pm 14$; and 9 samples from Guam, Eniwetok Atoll, Okinawa, and Ishigaki Island (Japan) produced a west subtropical Pacific mean value of $-94 \pm 46$ (Reimer and Reimer 2004). An additional sample from Guam has a $\Delta R$ value of $115 \pm 50$ (Athens 1986). These low tropical Pacific values, taken in conjunction with Masse's calculated negative value, suggest that application of a $\Delta R$ factor of zero to Palauan shellfish samples is reasonable until a precise localized correction factor is established through the dating of known-age shellfish collected prior to atmospheric bomb testing. ${ }^{5}$ Clark's excavations at Ulong have led him to believe that marine shell dates might not require a significant $\Delta R$ correction factor (2004:30), while Fitzpatrick (2002) has suggested that the local effects might be in the magnitude of -200 or $-300 \mathrm{yr}$ based on the disparity between an early shell date and associated metal tools. Masse's recent comparison of his revised marine shell ${ }^{14} \mathrm{C}$ dates with the new archaeological data tentatively suggest a $\Delta R$ of -200 to $-300 \mathrm{yr}$ (Masse et al., forthcoming).

Five sites have assays on stratigraphically contemporaneous charcoal/shell pairs: a $\sim 170$-cm-thick midden in Uchularois Cave (Masse 1989), ${ }^{6}$ deposits on Ulong Beach (Clark and Wright 2003; Clark 2004, forthcoming), the Chelechol ra Orrak and Omis Cave Yapese stone money quarries (Fitzpatrick 2002, 2003b), and the $\sim 150$-cm-thick Roischemiangel midden (Beardsley 1997). None of

\footnotetext{
${ }^{5}$ Though it is possible that $\Delta R$ values will be variable between islands in the Palauan archipelago due to differences in ocean currents and upwellings (S Fitzpatrick, personal communication, 2005), one study found that equatorial waters exhibit a roughly uniform ${ }^{14} \mathrm{C}$ enrichment (as compared with higher latitudes) due to geostrophic upwelling (Quay et al. 1983). The determination of a Palauan $\Delta R$ value is further complicated by decadal temperature fluctuations in the Pacific Ocean which have caused a decrease in upwelling of about $25 \%$ in an equatorial strip between $9^{\circ} \mathrm{N}$ and $9^{\circ} \mathrm{S}$ since the 1970 s (McPhaden and Zhang 2002).

${ }^{6}$ The Uchularois Cave midden was excavated by depths below surface rather than natural strata due to the uniformity of the soil in the feature (Masse 1989).
} 
the excavations aimed to match pairs for dating, and various site interpretations are made for vertical movement of the samples because of loose midden and coarse sediment, impacts by tidal action or storm waves, and stratigraphic disturbance due to burial activities and the quarrying of stone money. Taking the potential lack of a secure cultural context into consideration, by applying no $\Delta R$ value 9 of the 10 contemporaneous sets assessed as valid or possibly valid produce consistent dates.

The shellfish taxon used as datable material should be the primary component of midden assemblages, in order to reduce error from variations in molluscan feeding behavior and habitat effect (see Hogg et al. 1998). Calculated by relative abundance (MNI), the dominant mollusks found as food refuse in those Peleliu and Rock Island middens analyzed south of Babeldaob are Strombus gibberulus and Atactodea striata (Carucci 1992; Osborne 1979). Two Rock Island midden assemblages between Babeldaob and Koror show higher MNIs of Tellinacea and Anadara spp., though by weight one assemblage is dominated by Tridacnidae (Fitzpatrick 2003a). ${ }^{7}$ These taxa are deposit feeders commonly inhabiting sandy intertidal beaches; shallow, protected sand flats; and murky lagoon embayments. A potential exclusion from the dating pool is some members of the Tridacna spp., which is found in Palau's coastal sites. This taxon is long-lived, sometimes fossilized, as a tool material is often recycled, and can become an heirloom to be passed down for many generations (Masse $1989: 334)^{8}$

\section{Bone}

The suite of Palau ${ }^{14} \mathrm{C}$ dates includes 16 derived from bone (1 fish and 15 human). Bone assays rely primarily on the degree of diagenesis, as a poorly preserved sample will not produce an accurate date regardless of the chemical fraction dated or the purity of that fraction (Stafford et al. 1991; Hedges and van Klinken 1992; van Klinken 1999). Generally on Babeldaob, the acidic sediments produce high rates of degradation to datable material, but some proveniences have produced datable bone. Ten bone samples were collected from sand deposits in limestone caves (Fitzpatrick 2003b), three upon limestone in a cave (Reith and Liston 2001), and three from beach deposits (Titchenal et al. 1998; Ikehara, forthcoming.). Of these samples, 14 were dated at Stafford Research Lab, Inc. and the University of Arizona AMS facility, laboratories whose chemical pretreatment protocols are ranked as highly reliable (Stafford et al. 1991).

It is unnecessary to discard determinations due to the inability to separate diagenetic and indigenous carbonate in the inorganic bone matrix (as done by Phear et al. 2003:256), because ${ }^{14} \mathrm{C}$ assays derive from organic (collagen) rather than inorganic bone carbon. Furthermore, the absorption of calcium carbonate from the surrounding matrix - in this case, beaches and limestone caves - by inorganic bone carbon does not impact the ${ }^{14} \mathrm{C}$ dates on the collagen ( $\mathrm{T}$ W Stafford, personal communication, 2004). Humic acid, which along with fulvic acid is the predominate contaminate, is not a factor when samples are collected from deep limestone caves, the small entrances of which do not allow the intrusion of organics, as is the case with the Ngermereues Ridge burial cave (Reith and Liston 2001).

Exploitation of littoral and marine resources for dietary protein introduces the ocean reservoir effect into human bone collagen. The relative lack of indigenous terrestrial vertebrates (Pregill and Steadman 2000); an abundance of easily accessible marine resources in the large, shallow lagoon; and the dietary habits recorded in ethnographic accounts (Keate 1788; McCluer 1792) are strong indicators

\footnotetext{
${ }^{7}$ Variations in midden assemblages have been attributed to the ready accessibility of different marine habitats (O'Day 1999) and cultural differences in dietary or technological preferences (Fitzpatrick 2003a:121).

${ }^{8}$ Tridacna can live for 8 to $200 \mathrm{yr}$ depending on the species. The clams form seasonal growth bands in their shells, making it possible to age sections of dead shells (Delbeek and Sprung 1994).
} 
of a subsistence strategy dependent on seafood ${ }^{9}$ for protein-perhaps in the range of $\geq 70 \% .{ }^{10}$ Faunal analysis of midden from the Rock Islands (Osborne 1979; Masse 1989; Carucci 1992; Fitzpatrick 2003a) and from Babeldaob (O'Day 1999) record deposits composed almost exclusively of marine organisms. However, analysis of Rock Island middens may not accurately reflect the entirety of indigenous dietary habits, as land/sea birds, bats, lizards, or other terrestrial vertebrates were not as common as on Babeldaob and could be easily overexploited. An accurate reconstruction of prehistoric subsistence based on faunal analysis is difficult due to the scarcity of Babeldaob middens. Stable isotope analysis will thus need to complement faunal analysis to establish the relative importance of marine and terrestrial protein in the prehistoric diet (Lanting and van der Plicht 1998; Richards and Hedges 1999). The weighted average of the 10 available prehistoric Palauan values for $\delta^{13} \mathrm{C}(-15.7 \%)$ is only slightly higher than the suggested end-point values of $-12 \%$ and $-13.2 \%$ (Hobson and Collier 1984; Quinn 1990) for purely marine protein consumers in the Pacific. Once Palau's $\Delta R$ value is established, dietary reconstruction becomes crucial to obtaining valid bone assays.

\section{Pottery}

Twenty-one pottery assays are included in the Palau ${ }^{14} \mathrm{C}$ suite (Osborne 1979; Beardsley and Basilius 2002; S K Wickler, personal communication, 2004). Dating of pottery is undeniably problematic, as indicated by Masse $(1984,1989)$ and Osborne (1979), due to the presence of old carbon in grog-tempered sherds. Additionally, Phear et al. (2003:261) suggest that assays might be skewed due to "preserved plant remains in clays collected from swamp or slump deposits." A recent study by Anderson et al. (2005) compares paired samples of charcoal and pottery assays. Until the dating issues are resolved, all ${ }^{14} \mathrm{C}$ age determinations from pottery are eliminated from the dating pool.

\section{Charcoal}

${ }^{14} \mathrm{C}$ assays on carbonized wood number 266 with an additional six on pottery residue. The majority of the charcoal samples are taxonomically identified $(n=134), 41$ are determined to be woody taxa unidentifiable to species ${ }^{11}$ and the remaining 91 simply recognized as "charcoal." Identification of carbonized remains to taxon determines fitness for ${ }^{14} \mathrm{C}$ dating by reducing the error caused by longlived taxa, eliminating historical introductions or foreign driftwood, and ensuring fossil fuels are removed from the sample. ${ }^{12}$ Microscopic analysis can also differentiate anaerobically blackened wood from charcoal (G M Murakami, personal communication, 2004). As information on the longevity of taxa native to Palau is sparse, one of the better choices for ${ }^{14} \mathrm{C}$ assays is the short-lived coconut endocarp (Cocos nucifera).

Taxonomic identification of wood samples provides another level of credibility to ${ }^{14} \mathrm{C}$ assays by identifying species excavated from non-endemic habitats. Presence of a taxon in a non-native environment strongly suggests the anthropogenic origin of the sample. For example, Rhizophora spp. and Bruguiera spp. only grow in mangrove forests along the shore and Cocos nucifera is endemic

\footnotetext{
${ }^{9}$ The consumption of seabirds and shorebirds who feed on marine organisms contributes to the percent of marine protein found in collagen.

${ }^{10}$ For prehistoric Marianas populations, Ambrose et al. (1997) suggest that fish and shellfish comprised $20-50 \%$ of the protein source.

${ }^{11}$ This includes bark, charred plant tissue, and seed kernels.

${ }^{12}$ Minor deposits of lignite are interbedded with Airai clay and found in scattered patches on west and south Babeldaob (Corwin et al. 1956:53, 259).
} 
to the sandy back beach, ${ }^{13}$ but carbonized samples of these are found in upland deposits, indicating human intervention.

Small-scale excavations in Palauan earthworks often do not encounter cultural horizons or in situ features. In several of these cases, charcoal fragments scattered across a single stratum were combined in order to obtain a sample large enough to date the deposit. This dispersed sample will not affect the assay's standard error range but would expand the potential for error due to such factors as long-lived taxa and contamination. Furthermore, these samples do not date a specific point in time but are relative to the surrounding strata. In this context, the dispersed charcoal dates could provide meaningful data, but when taken in conjunction with the other complicating factors, they are not considered reliable unless collected in a single small-scale feature or if accompanied by other mitigating factors.

\section{STRATIGRAPHIC AND CULTURAL CONTEXT}

Once material suitability has been determined, sample context must be considered in assessing the validity of ${ }^{14} \mathrm{C}$ assays. Accepted as credible are samples originating from a discrete archaeological feature or forming tight, stratigraphically correct series. This universal protocol is technically sound but requires careful consideration in regard to the local site formation processes of Palau. Geologic, climatic, and anthropogenic events heavily impact primary site deposits in Palau. Identifying the origin of stratigraphic units and the relationship of associated cultural material is the key to dating Palauan archaeological sites.

On the Rock Islands site, disturbance occurs from storm waves, tidal action, downward infiltration of cultural material through the coarse sediment, and bioturbation. Masse (1989:288) found it "obvious that surface artifacts do not necessarily (if at all) represent the actual living surfaces of the original sites." He attributes the mixing of archaeological material to tree roots, crab scavenging, pig or rat disturbance, and megapodes constructing large mounds. Palau, just below the Pacific typhoon corridor, is directly hit or substantially impacted about every quarter of a century. The resulting storm waves are of such magnitude as to wash out, mix, and redeposit foreshore and reef flat environments far inland. In these highly disturbed deposits, artifacts from several cultural horizons can form what appear to be primary cultural deposits. Disturbances to Rock Island sites also occur as a result of engineering efforts related to Yapese stone money production and probably burial activities (Fitzpatrick 2002, 2003a).

Without the benefit of deeply penetrating primary forest roots, Babeldaob's clayey sediments are prone to slope-wash in the heavy tropical rains. Dramatic erosional episodes probably first occurred during land clearing for dryland agriculture ${ }^{14}$ and again during subsequent earthwork construction and maintenance. Downslope soil displacement resulting from this destabilization of the terrain washed away some sites, deeply covered others, and produced substantial sedimentation of the shoreline. Less than $20 \%$ of Babeldaob's coast is sandy beach, with the remainder being mangrove forests that proliferated as a result of this sedimentation. Some of the natural vertical movement of cultural material on Babeldaob is the result of the shrinking and subsequent cracking open of these dense clays in drought conditions. Scavenging by wild boars, rats, and domesticated pigs also results in site disturbance. Disturbed deposits in caves are attributed to their use as Yapese stone money

\footnotetext{
${ }^{13}$ It is possible, but highly unlikely, that a coconut tree could be naturally transplanted on a hilltop through a long sequence of nuts falling and regenerating upslope.

${ }^{14}$ With a dramatic erosional event, it can safely be assumed there was a cultural event upslope. Natural erosion can of course occur but it will not be so severe.
} 
quarries (Fitzpatrick 2002) and as World War II Japanese defensive positions, storage areas, or hideouts (Clark and Wright 2003; Pregill and Steadman 2000).

\section{Site Formation Processes: Earthworks}

Two types of monumental archaeological remains dominate Babeldaob: a sculpted landscape and large stonework villages. The immense earthworks, forming complexes of crowns, wide gullies, deep ditches, and varied forms of step-terraces, are found scattered across the landscape, on ridgelines and hills, across savannahs, and in dense forest. Their patterning is suggestive of their functioning as a means to define distinct areas of property, create defensible terrain, and to form symbols of individual chiefly or polity power (Liston 1999:412; Liston and Tuggle, forthcoming). More mundane functions for individual terraces within a complex include agriculture, habitation, and ceremonial and burial grounds. It is probable that a contemporaneous and integrated system of terrace functions was in effect from the onset of their construction, although their long duration of use suggests functional roles evolving to suit the needs of the changing communities (Liston and Tuggle 1998; Liston 1999). Earthworks cover about $20 \%$ of the island, with their impact on the landscape perhaps double that due to the intensive erosion resulting from their construction.

Palauan earthworks are created by complex cut-and-fill techniques. Within an overall architectural plan that relies on both the topography and the ultimate function of the feature, construction requires the procurement of fill material from near the site. Each donor site has its own depositional history, potentially including cultural horizons. These occupational surface(s) can be stripped off during construction episodes and redeposited to create seemingly primary cultural strata or be buried in intentional fill or erosional material. Ascertaining what event an assay is actually dating is dependent on careful stratigraphic analysis and interpretation of site formation processes in this heavily altered landscape. Redeposited layers are not always clearly recognizable, especially the heavily mottled units that are easily misinterpreted as basal saprolite. Combined fill and erosional material, as observed by the author, can be from 2 to 30 distinct strata, each ranging in thickness from $20 \mathrm{~cm}$ to a meter.

Determining chronologies for the monumental earthworks is difficult due to: 1) construction methods that produced a complicated depositional history; 2) episodic maintenance or additions to the original structure; 3 ) the sheer size of the earthworks, creating a daunting task for archaeological excavation; and 4) multifunctional and functionally evolving components requiring extensive rather than localized investigation of even a single complex for accurate interpretation. Dating is based, where possible, on assays derived from features associated with the various occupational surfaces. Features representing ultimate use are often buried by slope-wash or aeolian deposits, unrecognizable due to weathering of the early stone architecture, or actually a byproduct of continued activity in the area not associated with the terraces themselves. Creating a timeline for the construction and use of the earthworks, and for prior cultural activity on the landscape, requires integrating ${ }^{14} \mathrm{C}$ assays originating from secondary depositional units with securely dated features.

A chronology for terrace construction is established by the ${ }^{14} \mathrm{C}$ dating of several fill episodes, avoiding the assumption that greater depth equals older age. As datable material collected in a secondary context must derive from an event prior to its deposition, charcoal from a fill or erosional stratum gives a terminus ante quem for that layer since it could not have been deposited before that date. This same assay does not provide a terminus post quem for the stratum since the layers below are from various donor sites or in situ deposits of lesser or greater antiquity. Additionally, strata above the single assay might be younger or older. Therefore, dating of several fill or erosional episodes tightens the construction chronology considerably, with the youngest assay in the sequence provid- 
ing the last period of terrace (re)construction and the oldest assay indicating anthropogenic activity in the area whether or not associated with the earthworks. Since a thick erosional deposit is probably anthropogenically induced, a ${ }^{14} \mathrm{C}$ date from the deposit indicates upslope cultural activities possibly related to deforestization or earthwork construction. Identification of the charcoal sample to a taxon foreign to the local habitat confirms human presence. However, in establishing construction chronologies it is irrelevant whether the charcoal samples are associated with cultural material, or even cultural in origin, since they are producing relative rather than specific ${ }^{14} \mathrm{C}$ age determinations.

\section{DISCUSSION}

A meaningful depiction of Palauan prehistory can only be developed when all the environmental zones, site types, and regions are adequately represented in the suite of ${ }^{14} \mathrm{C}$ assays. Each reveals temporal and spatial aspects in the transformations of Palau's settlement patterns, subsistence practices, and social organization. Despite the large quantity of reliable Palauan ${ }^{14} \mathrm{C}$ determinations, examination and comparison of their provenience disclose the relative inadequacy of the sample size in most of the regions and some ecozones and site types. The majority of Palau's assays are from areas of Babeldaob where cultural resource management regulations required archaeological research prior to construction projects. These investigations, specifically work on the Compact Road, provided a rare opportunity to sample a wide distribution of site types broadly dispersed throughout Palau. ${ }^{14} \mathrm{C}$ assays concluded to be valid are listed by site type and environmental zone in Table 1 and by region in Table 2.

Table 1 Palauan ${ }^{14} \mathrm{C}$ dates assessed as valid, listed by site type, number of sites (in parentheses), and environmental zone. ${ }^{\mathrm{a}}$

\begin{tabular}{lllllll}
\hline Environmental zones & $\begin{array}{l}\text { Stonework } \\
\text { village }\end{array}$ & $\begin{array}{l}\text { Earthwork } \\
\text { complex }\end{array}$ & $\begin{array}{l}\text { Earthworks } \\
\text { with stonework }\end{array}$ & $\begin{array}{l}\text { Island } \\
\text { midden/cave }\end{array}$ & Other & Total \\
\hline Peleliu/Angaur & - & - & - & $12(2)$ & $2(1)$ & $14(3)$ \\
Rock Islands & $10(4)$ & - & - & $46(5)$ & - & $56(9)$ \\
Southwest Islands & $5(3)$ & - & - & - & - & $5(3)$ \\
Coastline (Babeldaob) & $33(6)$ & - & - & - & $5(2)$ & $38(8)$ \\
Lowlands & $23(4)$ & $51(11)$ & $4(4)$ & - & - & $78(19)$ \\
Uplands & - & $8(2)$ & $37(7)$ & - & $1(1)$ & $46(10)$ \\
\hline
\end{tabular}

${ }^{a}$ The list does not include all the Palauan site types but only those with valid ${ }^{14} \mathrm{C}$ determinations.

Containing over $50 \%$ of the valid dates $(n=128)$ and almost $50 \%$ of the number of sites $(n=25)$, the data set is heavily weighted in the Ngaraard and Rock Island regions. ${ }^{15}$ Ten of the 15 regions are each represented by less than $9{ }^{14} \mathrm{C}$ dates, five of those having none or only one. Almost a third of the assays are from stonework village sites, with the remainder fairly evenly distributed across the earthwork complex, earthwork with stonework, and Rock Island or Peleliu midden and cave site types. It is evident that many locales either not in the path of the Compact Road or specifically targeted for academic research require further investigations to attain a suitably representative data set.

The coastal zone encompasses Babeldaob's $157-\mathrm{km}$-long shoreline, $125 \mathrm{~km}$ of which is mangrove forests. Once largely sandy beach, Babeldaob's coastal margin with its abundant resources is more

\footnotetext{
${ }^{15}$ On Babeldaob, the regions are equivalent to Palau's modern political states, once traditional districts, which are largely environmentally definable by mountain ridges and drainages. Palau's islands are divided into 4 categories due to the great expanse of ocean separating the Southwest Islands from the others and the biological and geological differences between the Rock Islands, Peleliu, Angaur, and Kayangel.
} 
Table 2 Palauan ${ }^{14} \mathrm{C}$ dates assessed as valid in archaeological sites listed by region.

\begin{tabular}{lr}
\hline Region & Nr of assays (nr of sites) \\
\hline Aimeliik & $4(1)$ \\
Airai & 1 (1) \\
Kayangel & 0 \\
Koror & $6(3)$ \\
Melekeok & $9(2)$ \\
Ngaraard & $72(16)$ \\
Ngarchelong & $3(3)$ \\
Ngardmau & 0 \\
Ngaremlengui & 0 \\
Ngatpang & $40(4)$ \\
Ngchesar & $1(1)$ \\
Ngiwal & $26(6)$ \\
Peleliu/Angaur & $14(3)$ \\
Rock islands & $56(9)$ \\
Southwest islands & $5(3)$ \\
Total & $237(52)$ \\
\hline
\end{tabular}

suitable for habitation than the Rock Islands and was the location of initial Palauan settlement. Stonework villages are commonly located in the coastal zone behind a protective band of mangrove forest. All but three of the assays from this ecozone originate inland of the mangroves, not from back beach or shoreline deposits, while the earliest ${ }^{14} \mathrm{C}$ determinations are derived from deposits underlying the stonework villages ${ }^{16}$ at Eoulbeluu (cal AD 70-390, WK-5938) and Ngerdubech (cal $\mathrm{AD} 1-250$, WK-6466), the latter date being only potentially valid. The lack of early dates from Babeldaob's coastal zone is not surprising as evidence of these sites is difficult to locate due to an initially small population, sea-level change, progradation, sedimentation resulting in mangrove growth, and deterioration of bone and shell. Cultural properties found behind the sandy coastal plains in Melekeok, Ngiwal, Ngaraard, and Ngarchelong are not represented by ${ }^{14} \mathrm{C}$ age determinations. Shorelines of large, deep inlets that can provide a wide range of resources and protection from encroaching storm waves and attacks by adversarial villages have a high probability of containing early sites. ${ }^{17}$ Only a focused area of stonework villages in Ngeremeduu Bay and a Rock Island inside Airai Bay has been investigated.

A third of Palau's valid ${ }^{14} \mathrm{C}$ assays are from the lowlands, a strip of land between the coastal zone and the base of the interior ridges. Circling the majority of Babeldaob, this zone is composed of low, gently rolling hills often covered in savanna and is the location of most of the monumental earthworks. Though the ecozone and site type are well represented in the dating pool, regions within the zone are not. Of the $78{ }^{14} \mathrm{C}$ determinations from the lowlands, 59 of them originate in Ngatpang, Ngaraard, and Ngiwal. Aimeliik and Ngaremlengui (with two of the largest earthwork and village complexes on Babeldaob), Ngardmau, and the Badrulchau region of Ngarchelong have been minimally tested. Eighteen assays are from villages represented by early stone architecture found associated with some earthworks. Seven crown sites, 5 sets of step-terraces, and 3 earthwork complexes are represented in the lowland earthwork assays. There are few assays from the broad, low step-ter-

\footnotetext{
${ }^{16}$ These early dates are not associated with the stonework structures and indicate occupation of the area prior to the development of stonework villages (Liston 1999).

${ }^{17}$ These include Ngemai, Ngerchemiangl, Ngeremeduu, and Airai bays, particularly the latter two.
} 
race sites such as those found along Airai's east coast. The diverse types of earthworks require additional investigations in the various regions.

All 46 of the ${ }^{14} \mathrm{C}$ determinations from the upland ridge systems, which extend the length of Babeldaob, are concentrated along the narrow neck of the island in Ngaraard. These dates are only from sites in the northern half of this $\sim 4.5-\mathrm{km}$-long monumental earthwork complex, which is composed of crowns, various forms of step-terraces, ditches, gullies, earth platforms, and early stone architecture. The earliest date recorded thus far in Palau, 1520-1260 cal BC (WK-13974), is from an upland deposit. An anthropogenic origin of the carbonized sample of Cynometra ramiflora is indicated by its presence in a non-endemic habitat. This ecozone, the least investigated of the 3 Babeldaob zones, contains previously unrecorded earthwork sites, early stone architecture, dense artifact scatters, and ridgeline trail systems.

As a region and an environmental zone, the Rock Islands are well represented in Palau's suite of ${ }^{14} \mathrm{C}$ assays, a reflection of both the number of investigations conducted there and the superior quality of preservation in sand and cave deposits. These islands were originally sites for fishing parties, burial grounds, temporary camps, and other short-term activities, although their use later expanded to encompass permanent habitation sites. Some of Palau's earliest ${ }^{14} \mathrm{C}$ assays have been unearthed at Chelechol ra Orrak (1000-830 cal BC, OS-33568) and Ulong Island (950-350 cal BC, ANU11933).

Kayangel has no ${ }^{14} \mathrm{C}$ dates assessed as valid. Several large storms have sent waves completely across the narrow islands that encompass the atoll and it may be difficult to locate undisturbed deposits. Both archaeological sites excavated in Peleliu are shell middens and the one in Angaur is a habitation site. As in Kayangel, intact prehistoric cultural deposits are likely intermittent, as Angaur was heavily mined for phosphate and both islands were occupied by Allied forces in World War II, with Peleliu being home to one of the major battles of the Pacific. The 5 Southwest Island dates are from a cultural deposit, earth-oven refuse, and an earth platform mound, all associated with village habitation.

Palau's 237 reliable ${ }^{14} \mathrm{C}$ dates are considerably more than found in most Micronesian islands and much can be proposed about colonization, settlement patterns, and cultural change. However, to encompass the entire span of prehistory in Palau's chronological models, to ensure its meaningfulness the dating pool needs to be augmented by assays originating outside of Ngaraard's upland earthwork complex, the stonework villages of Ngatpang, and the Ngiwal ridgeline. Sites in Aimeliik, Airai, Melekeok, Ngarchelong, Ngardmau, and Ngchesar, particularly those found along the coast and inner bays and the upland ridge system as well as the massive earthwork and village complexes should be investigated. Additional ${ }^{14} \mathrm{C}$ determinations are needed from Babeldaob and Rock Island stonework villages, as despite the large quantity of assays from these sites, only 17, or $7 \%$, of potentially over 235 villages ${ }^{18}$ have been tested. Grant-funded research, not limited to work inside construction parcels, has the freedom to enlarge the corpus of dates from specific areas that have not been adequately investigated. Despite the need for a broader range of ${ }^{14} \mathrm{C}$ dates, this study has provided a solid foundation on which colonization and cultural chronologies for Palau can be developed.

Temporal horizon markers, independent of ${ }^{14} \mathrm{C}$ dates, serve as a reference point for dating. Architectural types-large earthwork complexes and early stone architecture, both prior to stonework villages - provide only a basic temporal horizon marker in Palauan prehistory. While previous studies

${ }^{18}$ In 1910, Krämer (1919) counted 235 stonework villages on Babeldaob and Koror, including 151 that had been abandoned. 
(Osborne 1966; Snyder 1989) were unable to establish a chronometric timeline for ceramic styles, enough data are now available to develop such a model (Clark 2004, forthcoming; Desilets et al. 1999; Liston, forthcoming a, b). Until there is a reliable and comprehensive ceramic sequence, Palauan chronologies must rely almost solely on ${ }^{14} \mathrm{C}$ dates as reference points, a "system of data generation that is inherently flawed by a lack of meaningful checks" (Tuggle and Tuggle 1997:74). The establishment of a relative ceramic chronology to serve as an independent temporal horizon marker is essential for continued archaeological work in Palau.

\section{ACKNOWLEDGMENTS}

This paper is based largely on research carried out by International Archaeological Research Institute, Inc. for the US Army Corps of Engineers, Pacific Ocean Division, as part of the historic preservation actions associated with the construction of the Compact Road in the Republic of Palau, from 1996 through 2004. For the opportunity to carry out this work, I am indebted to Chuck Streck of the US Army Corps of Engineers, to Vicky Kanai (Chief) and Rita Olsudong (Senior Archaeologist) at the Palau Bureau of Arts and Culture, and to the people of Palau. For permission to include ${ }^{14} \mathrm{C}$ determinations that are not yet published, I thank Atholl Anderson, Geoff Clark, Scott Fitzpatrick, Sarah Phear, Steve Wickler, and Duncan Wright. I am grateful to Tom Dye, Fiona Petchey, Emma Power, Tim Rieth, and Dave Tuggle for their valuable assistance and helpful comments on this paper and to Scott Fitzpatrick for providing his detailed and careful review of the manuscript. I am greatly indebted to all the field and lab archaeologists who worked on the Compact Road project over the years. Although many contributed to the research, the mistakes, interpretations, and conclusions presented in this manuscript are those of the author.

\section{REFERENCES}

Addison DJ. 1997. Survey Area D report. In: Wickler SK, Welch DJ, Tomonari-Tuggle MJ, editors. Compact Road archaeological investigations, Babeldaob Island, Republic of Palau, historic preservation investigations phase I. Volume II: area survey reports [draft report prepared for US Army Corps of Engineers, Pacific Ocean Division]. Honolulu: International Archaeological Research Institute, Inc. p 435-550.

Ambrose SH, Butler BM, Hanson DB, Hunter-Anderson RL, Krueger HW. 1997. Stable isotopic analysis of human diet in the Marianas archipelago, western Pacific. American Journal of Physical Anthropology 104:343-61.

Anderson AJ. 1991. The chronology of colonization in New Zealand. Antiquity 65:767-95.

Anderson AJ, Chappell G, Clark G, Phear S. 2005. Comparative radiocarbon dating of pottery and charcoal samples from Babeldaob Island, Republic of Palau. Radiocarbon 47(1):1-9.

Athens JS. 1986. Archaeological investigations at Tarague Beach, Guam [report prepared for Base Civil Engineering, Anderson Air Force Base, Guam]. Honolulu: International Archaeological Research Institute, Inc.

Athens JS, Ward JV. 2001. Paleoenvironmental evidence for early human settlement in Palau: the Ngerchau core. In: Stevenson CM, Morin FJ, editors. Pacific 2000: Proceedings of the Fifth International Confer- ence on Easter Island and the Pacific. Los Osos: Easter Island Foundation. p 165-78.

Athens JS, Ward JV. 2002. Holocene paleoenvironmental investigations on Ngerekebesang, Koror, South Babeldaob, and Peleliu islands, Palau [report prepared for Palau National Communications Corporation, $\mathrm{Pa}$ lau]. Honolulu: International Archaeological Research Institute, Inc.

Athens JS, Ward JV. 2005. Palau Compact Road archaeological investigations, Babeldaob Island, Republic of Palau, phase I: intensive archaeological survey. Volume IV: Holocene paleoenvironment and landscape change [report prepared for US Army Corps of Engineers, Pacific Ocean Division]. Honolulu: International Archaeological Research Institute, Inc.

Beardsley FR. 1996. Fragments of paradise: archaeological investigations in the Republic of Palau, Palau rural water system survey and testing [report prepared for Winzler and Kelly, Consulting Engineers, Palau]. Honolulu: International Archaeological Research Institute, Inc.

Beardsley FR. 1997. Fishponds, taro patches and shell middens: archaeological investigations on Peleliu, Republic of Palau, data recovery and monitoring for the Palau rural water system program [report prepared for Winzler and Kelly, Consulting Engineers, Palau] Honolulu: International Archaeological Research Institute, Inc. 
Beardsley FR. Forthcoming. Archaeological monitoring for the Palau National Communication Corporation: Airai and Koror, Republic of Palau [draft report prepared for Palau National Communications Corporation]. Honolulu: International Archaeological Research Institute, Inc.

Beardsley FR, Basilius U. 2002. Sengall Ridge, Belau: burials, spirit walks, and painted pottery. Indio-Pacific Prehistory Association Bulletin: Melaka Papers 6(22):147-51.

Butler BM. 1985. New radiocarbon dates from Palau. The Outrigger: Newsletter of Micronesian Archaeology 4(2):2-3. Carbondale: Southern Illinois University.

Carucci J. 1992. Cultural and natural patterning in prehistoric marine foodshell from Palau, Micronesia [PhD dissertation]. Carbondale: Southern Illinois University.

Clark G. 2004. Radiocarbon dates from the Ulong site in Palau and implications for western Micronesian prehistory. Archaeology in Oceania 39:26-33.

Clark G. Forthcoming. A 3000-year culture sequence from Palau, western Micronesia. Archaeology in Oceania.

Clark G, Wright D. 2002. Report on excavations at Angaur and Ulong, Republic of Palau [typescript]. Palau Bureau of Arts and Culture Library.

Clark G Wright D. 2003. The colonization of Palau: preliminary results from Angaur and Ulong. In: Sand C, editor. Pacific Archaeology: Assessments and Prospects. Les Cahiers de l'Archéologie en NouvelleCalédonie 15. Nouméa: Musee de Nouvelle-Calédonie. p 85-94.

Clark G Wright D. Forthcoming. On the periphery? Archaeological investigations at Ngelong, Angaur Island, Palau. Micronesica.

Corwin CG, Rogers CL, Elmquist PO. 1956. Military geology of Palau Islands, Caroline Islands [military report]. Intelligence Division, Office of the Engineer. Headquarters US Army Forces Far East.

Delbeek JC, Sprung J. 1994. The Reef Aquarium: Volume One. Coconut Grove, Florida, USA: Ricordea Publishing.

Desilets M, Liston J, Tuggle HD. 1999. Ceramic analysis. In: Tomanari-Tuggle MJ, Tuggle HD, Liston J, Welch DJ, editors. Archaeological data recovery for the Compact Road, Babeldaob Island, Republic of $\mathrm{Pa}$ lau. Volume V: lab analysis, synthesis, and recommendations [draft report prepared for US Army Corps of Engineers, Pacific Ocean Division]. Honolulu: International Archaeological Research Institute, Inc. p 181-230.

Dye TS. 1997. Survey Area A report. In: Wickler SK, Welch DJ, Tomonari-Tuggle MJ, editors. Compact Road archaeological investigations, Babeldaob Island, Republic of Palau, historic preservation investigations phase I. Volume II: area survey reports [draft report prepared for US Army Corps of Engineers, Pacific Ocean Division]. Honolulu: International Archaeological Research Institute, Inc. p 19-98.

Fitzpatrick SM. 2002. A radiocarbon chronology of Yapese stone money quarries in Palau. Micronesica 34(2):227-42.

Fitzpatrick SM. 2003a. Shellfish assemblages from two limestone quarries in the Palau Islands. Journal of Ethnobiology 23(1):101-23.

Fitzpatrick SM. 2003b. Early human burials in the western Pacific: evidence for a c. 3000-year-old occupation on Palau. Antiquity 77(298):719-31.

Fitzpatrick SM, Boyle JE. 2002. The antiquity of pearl shell (Pinctada sp.) burial artifacts in Palau, western Micronesia. Radiocarbon 44(3):691-9.

Hayakawa S. 1979. Archaeological investigation of PAKR-3 in the Palaus. In: Kusakabe F, editor. Cultural Anthropological Research on the Folk Culture in the Western Caroline Islands of Micronesia in 1977. Tokyo: Tokyo University of Foreign Studies. p 73-8.

Hedges REM, van Klinken GJ. 1992. A review of current approaches in the pretreatment of bone for radiocarbon dating by AMS. Radiocarbon 34(3):279-91.

Henry JD, Haun AE, Kirkendall MA. 1996. Archaeological mitigation program: Palau rural water system projects in Chol and Ngkeklau villages, Ngaraard State, Republic of Palau [draft report prepared for Monterey Mechanical]. Hilo, Hawai'i: Paul H Rosendahl, $\mathrm{PhD}$, Inc.

Hobson KA, Collier S. 1984. Marine and terrestrial protein in Australian aboriginal diets. Current Anthropology 25:238-40.

Hogg AG, Higham TFG, Dahm J. 1998. Radiocarbon dating of modern marine and estuarine shellfish. Radiocarbon 40(2):975-84.

Hunter-Anderson RL. 1992. Archaeological investigations in the Southwest Islands of Palau (Tobi, Merir, Pulo Ano, Sonsorol, Fana) [prepared for the Republic of Palau via The Nature Conservancy, Pacific Region]. Micronesian Archaeological Research Services, Guam.

Intoh M, Ono R. 2004. Reconnaissance archaeological research on Tobi Island, Hatohobei State, Palau [report prepared for Palau National Historic Preservation Office].

Ito M, Ono M, Nakamura T. 1997. Preliminary report on excavation and radiocarbon dating of ked in Palau (Part 1). Summaries of research using AMS at Nagoya University (VIII-March 1997). Nagoya: Dating and Materials Research Center, Nagoya University.

Ito M, Ono M, Nalamura T. 1998. Preliminary report on excavation and radiocarbon dating of ked in Palau (Part 8). Summaries of research using AMS at Nagoya University (IX-March 1998). Nagoya: Dating and Materials Research Center, Nagoya University.

Ikehara R. Forthcoming. Ngiwal human burials. In: Liston $\mathrm{J}$, editor. Archaeological testing and monitoring 
for the Palau National Communication Corporation: Angaur, Babeldaob, Kayangel, and Peleliu, Republic of Palau [draft report prepared for Palau National Communications Corporation]. Honolulu: International Archaeological Research Institute, Inc.

Kaschko MW. 1997. Survey Area C report. In: Wickler SK, Welch DJ, Tomonari-Tuggle MJ, editors. Compact Road archaeological investigations, Babeldaob Island, Republic of Palau, historic preservation investigations phase I. Volume II: area survey reports [draft report prepared for US Army Corps of Engineers, Pacific Ocean Division]. Honolulu: International Archaeological Research Institute, Inc. p 329-434.

Kaschko MW. 1998a. Ngaraard site reports. In: Liston J, Tuggle HD, Tomanari-Tuggle MJ, Desilets M, editors. Compact Road archaeological investigations, Babeldaob Island, Republic of Palau, historic preservation investigations phase II. Volume I: fieldwork reports [draft report prepared for US Army Corps of Engineers, Pacific Ocean Division]. Honolulu: International Archaeological Research Institute, Inc. p 134-50.

Kaschko MW. 1998b. Ngiwal site reports. In: Liston J, Desilets M, Tuggle HD, editors. Compact Road archaeological investigations, Babeldaob Island, Republic of Palau, historic preservation investigations phase II. Volume II: fieldwork reports [draft report prepared for US Army Corps of Engineers, Pacific Ocean Division]. Honolulu: International Archaeological Research Institute, Inc. p 25-110.

Keate G. 1788. An Account of the Pelew Islands, Situated in the Western Part of the Pacific Ocean, Composed from the Journals and Communications of Captain Henry Wilson, and Some of His Officers, Who, in August 1783, Were There Shipwrecked, in The Antelope, A Packet Belonging to the Honourable East India Company. London: G Nicol.

Krämer A. 1919. Palau ethnography. In: Thilenius G, editor. Ergebnisse der Südsee-Expedition 1908-1910. II. Ethnographie; B. Mikronesien. Band 3, Teilband 2. Friederichsen, Hamburg [typescript]. Human Relations Area File typescript, translated by Anonymous.

Lanting JN, van der Plicht J. 1998. Reservoir effects and apparent ${ }^{14} \mathrm{C}$ ages. The Journal of Irish Archaeology IX:151-65.

Liston J. 1998. Ngatpang site reports. In: Liston J, Desilets M, Tuggle HD, editors. Compact Road archaeological investigations, Babeldaob Island, Republic of Palau, historic preservation investigations phase II. Volume II: fieldwork reports [draft report prepared for US Army Corps of Engineers, Pacific Ocean Division]. Honolulu: International Archaeological Research Institute, Inc. p 111-22, 237-53.

Liston J. 1999. Archaeological data recovery for the Compact Road, Babeldaob Island, Republic of Palau. Volume V: lab analysis, synthesis, and recommendations [draft report prepared for US Army Corps of En- gineers, Pacific Ocean Division]. Honolulu: International Archaeological Research Institute, Inc.

Liston J. Forthcoming a. Palau Compact Road, archaeological investigations, Babeldaob Island, Republic of Palau. Phase III: archaeological monitoring. Volume $\mathrm{X}$ : field reports [draft report prepared for US Army Corps of Engineers, Pacific Ocean Division]. Honolulu: International Archaeological Research Institute, Inc.

Liston J. Forthcoming b. Palau Compact Road, archaeological investigations, Babeldaob Island, Republic of Palau. Phase III: archaeological monitoring. Volume $\mathrm{XI}$ : laboratory analysis and comprehensive project synthesis [draft report prepared for US Army Corps of Engineers, Pacific Ocean Division]. Honolulu: International Archaeological Research Institute, Inc.

Liston J, Kaschko MW, Welch DW. 1998. Archaeological inventory survey of the capital relocation site, Melekeok, Republic of Palau [report prepared for Architects Hawaii, Inc]. Honolulu: International Archaeological Research Institute, Inc.

Liston J, Tuggle HD. 1998. The terraces of Palau: new information on function and age. Paper presented at the 63rd Meeting of the Society for American Archaeology, Seattle, Washington, 25-29 March 1998.

Liston J, Tuggle HD. Forthcoming. Prehistoric warfare in Palau. In: Arkush E, Allen MW, editors. Archaeology of Warfare: Prehistories of Raiding and Conquest. Gainesville: University Press of Florida.

Lucking LJ. 1984. An archaeological investigation of prehistoric Palauan terraces [ $\mathrm{PhD}$ dissertation]. Minneapolis: University of Minnesota.

Magnuson CM, Liston J. 1998. Archaeological inventory survey, Palau Peninsula resort, Ngerekebesang Island, Koror, Republic of Palau [draft report prepared for Haas and Haynie, South San Francisco, California]. Honolulu: International Archaeological Research Institute, Inc.

Mangieri TM. 1998a. Ngaraard site reports. In: Liston J, Tuggle HD, Tomanari-Tuggle MJ, Desilets M, editors. Compact Road archaeological investigations, Babeldaob Island, Republic of Palau, historic preservation investigations phase II. Volume I: fieldwork reports [draft report prepared for US Army Corps of Engineers, Pacific Ocean Division]. Honolulu: International Archaeological Research Institute, Inc. p 212-314.

Mangieri TM. 1998b. Ngatpang site reports. In: Liston J, Desilets M, Tuggle HD, editors. Compact Road archaeological investigations, Babeldaob Island, Republic of Palau, historic preservation investigations phase II. Volume II: fieldwork reports [draft report prepared for US Army Corps of Engineers, Pacific Ocean Division]. Honolulu: International Archaeological Research Institute, Inc. p 163-236.

Mangieri TM. Forthcoming. Ngaraard site reports. Palau Compact Road, archaeological investigations, Ba- 
beldaob Island, Republic of Palau. Phase III: archaeological monitoring. Volume IX: emergency data recovery [draft report prepared for US Army Corps of Engineers, Pacific Ocean Division]. Honolulu: International Archaeological Research Institute, Inc.

Masse WB. 1984. Radiocarbon dating in the Palau Islands, Micronesia [typescript]. Carbondale: Center for Archaeological Investigations, Southern Illinois University.

Masse WB. 1989. The archaeology and ecology of fishing in the Beleu Islands, Micronesia [PhD dissertation]. Carbondale: Southern Illinois University.

Masse WB. 1990. Radiocarbon dating, sea-level change, and the peopling of Belau. In: Hunter-Anderson R, editor. Micronesica Supplement 2:213-30.

Masse WB, Snyder D. 1982. The final report of the 1981 field season of the Southern Illinois University Palau archaeological project [report prepared for Historic Preservation Office, US Trust Territory of the Pacific Islands, Saipan]. Carbondale: Center for Archaeological Investigations, Southern Illinois University.

Masse WB, Liston J, Carucci J, Athens JS. Forthcoming. Evaluating the effects of climate change on environment, resource depletion, and culture in the Palau Islands between $\mathrm{AD} 1200$ and 1600. Quaternary International.

McCluer J. 1792. Voyage to the Pelew Islands in the H C Snow Panther [typescript]. Palau Museum (typescript 1974).

McPhaden MJ, Zhang D. 2002. Slowdown of the meridional overturning circulation in the upper Pacific Ocean. Nature 415(7):603-8.

O'Day S. 1999. Invertebrate faunal remains. In: Liston J, editor. Archaeological data recovery for the Compact Road, Babeldaob Island, Republic of Palau. Volume $\mathrm{V}$ : lab analysis, synthesis, and recommendations. [draft report prepared for US Army Corps of Engineers, Pacific Ocean Division]. Honolulu: International Archaeological Research Institute, Inc. p 115-25.

Olmo RK. 1998. Archaeological research of the terrace site for the concrete plant in Ngersung area, Ngerusar, Airai State, Republic of Palau [report prepared for Surangel \& Sons Co., Palau]. Honolulu: International Archaeological Research Institute, Inc.

Osborne D. 1966. The Archaeology of the Palau Islands, An Intensive Survey. BP Bishop Museum Bulletin 230. Honolulu: Bishop Museum Press. 494 p.

Osborne D. 1979. Archaeological test excavations, Palau Islands, 1968-1969. Micronesia Supplement 1.

Pantaleo J. 2000. Archaeological data recovery procedures for the proposed Palau capital relocation project, phase I-A, Ngerulmud Hill, Melekeok State, Republic of Palau [draft report prepared for Palau Capital Improvements Project Office, Division of Public Works, Palau]. Honolulu: Jeffrey Pantaleo Consultants, LLC.

Phear S. 2003. Painted pottery in Palau: new evidence challenges past interpretations [WWW document]. Antiquity Project Gallery 7(296). URL: <http://antiquity.ac.uk/ProjGall/phear/phear.html>. Accessed 17 May 2004.

Phear S. 2004. The monumental earthworks of Palau, Micronesia: a landscape perspective $[\mathrm{PhD}$ dissertation]. Canberra: Australia National University.

Phear S, Clark G, Anderson A. 2003. A radiocarbon chronology of Palau. In: Sand C, editor. Pacific Archaeology: Assessments and Prospects. Les Cahiers de l'Archéologie en Nouvelle-Calédonie 15. Nouméa: Musee de Nouvelle-Calédonie. p 255-63.

Pregill GK, Steadman DW. 2000. Fossil vertebrates from Palau, Micronesia: a resource assessment. Micronesica 33(1/2):137-52.

Quay PD, Stuiver M, Broecker WS. 1983. Upwelling rates for the equatorial Pacific Ocean derived from the bomb ${ }^{14} \mathrm{C}$ distribution. Journal of Marine Research 41:769-92.

Quinn CJ. 1990. Stable isotopes and diet: indications of the marine and terrestrial components in the diets of prehistoric populations from New Zealand and the $\mathrm{Pa}$ cific [MA thesis]. Dunedin: University of Otago.

Reimer PJ, Reimer R. 2004. Marine reservoir correction database [WWW document]. URL: <http://calib.org/ marine/>. Accessed 11 June 2004.

Richards MP, Hedges REM. 1999. Stable isotope evidence for similarities in the types of marine foods used by late Mesolithic humans at sites along the Atlantic coast of Europe. Journal of Archaeological Science 26:717-22.

Rieth TM, Liston J. 2001. Archaeological data recovery at Ngermereues Ridge, Ngesaol, Koror, Republic of Palau [report prepared for Winzler and Kelly, Consulting Engineers, Palau]. Honolulu: International Archaeological Research Institute, Inc.

Snyder D. 1983. Archaeological surveys in Ngardmau and Ngchesar, Republic of Palau [typescript]. Carbondale: Center for Archaeological Investigations, Southern Illinois University.

Snyder D. 1989. Towards chronometric models for Palauan prehistory: ceramic attributes $[\mathrm{PhD}$ dissertation]. Carbondale: Southern Illinois University.

Spriggs M, Anderson A. 1993. Late colonization of east Polynesia. Antiquity 67(255):200-17.

Stafford TW Jr, Hare PE, Currie L, Jull AJT, Donahue DJ. 1991. Accelerator radiocarbon dating at the molecular level. Journal of Archaeological Science 18: 35-72.

Stuiver M, Reimer PJ. 1993. Extended ${ }^{14} \mathrm{C}$ database and revised CALIB $3.0{ }^{14} \mathrm{C}$ age calibration. Radiocarbon 28(2B):1022-30.

Stuiver M, Reimer PJ, Bard E, Beck JW, Burr GS, Hughen KA, Kromer B, McCormac G, van der Plicht J, Spurk M. 1998. IntCal98 radiocarbon age calibration, 24,000-0 cal BP. Radiocarbon 40(3):1041-83.

Takayama J. 1979. Archaeological investigations of 
PATT-2 in the Palaus: an interim report. In: Kusakabe F, editor. Cultural Anthropological Research on the Folk Culture in the Western Caroline Islands of Micronesia in 1977. Tokyo: Tokyo University of Foreign Studies. p 81-103.

Takayama J, Intoh M, Takasugi H. 1980. The brief archaeological survey on Kayangel and Angaur, in the Palaus. Pacific Archaeological Survey Report VII. Nara City: Tezukayama University.

Titchenal P, Drolet R, Pantaleo J. 1998. Ngiwal: archaeological data recovery and monitoring in a rural village on Babeldaob in the Republic of Palau [draft report prepared for Palau Capital Improvements Projects Office, Division of Public Works, Palau]. Honolulu: Garcia and Associates.

Tuggle HD. 1998a. Ngaraard site reports. In: Liston J, Tuggle HD, Tomanari-Tuggle MJ, Desilets M, editors. Compact Road archaeological investigations, Babeldaob Island, Republic of Palau, historic preservation investigations phase II. Volume I: fieldwork reports [draft report prepared for US Army Corps of Engineers, Pacific Ocean Division]. Honolulu: International Archaeological Research Institute, Inc. p 81-129, 150-97, 314-424.

Tuggle HD. 1998b. Ngatpang site reports. In: Liston J, Desilets M, Tuggle HD, editors. Compact Road archaeological investigations, Babeldaob Island, Republic of Palau, historic preservation investigations phase II. Volume II: fieldwork reports [draft report prepared for US Army Corps of Engineers, Pacific Ocean Division]. Honolulu: International Archaeological Research Institute, Inc. p 126-46.

Tuggle HD. Forthcoming. Palau Compact Road, archaeological investigations, Babeldaob Island, Republic of Palau. Phase III: archaeological monitoring. Volume IX: emergency data recovery [draft report prepared for
US Army Corps of Engineers, Pacific Ocean Division]. Honolulu: International Archaeological Research Institute, Inc.

Tuggle HD, Tomonari-Tuggle MJ. 1997. Synthesis of cultural resource studies of the Ewa Plain. Task 1a: archaeological research services for the proposed cleanup, disposal, and reuse of Naval Air Station Barbers Point, Oahu, Hawaii [report prepared for Belt Collins Hawaii]. Honolulu: International Archaeological Research Institute, Inc.

van Klinken GJ. 1999. Bone collagen quality indicators for paleodietary and radiocarbon measurement. Journal of Archaeological Science 26:687-95.

Wickler SK. 1997. Survey Area B report. In: Wickler SK, Welch DJ, Tomonari-Tuggle MJ, editors. Compact Road archaeological investigations, Babeldaob Island, Republic of Palau, historic preservation investigations phase I. Volume II: area survey reports [draft report prepared for US Army Corps of Engineers, Pacific Ocean Division]. Honolulu: International Archaeological Research Institute, Inc. p 99-328.

Wickler SK, Welch DJ, Tomonari-Tuggle MJ, Liston J, Tuggle HD. 1998. Intensive archaeological survey for the Palau Compact Road, Babeldaob Island, Republic of Palau, historic preservation investigations phase I. Volume I: scope, background, results, evaluation, and recommendation [draft report prepared for US Army Corps of Engineers, Pacific Ocean Division]. Honolulu: International Archaeological Research Institute, Inc.

Wickler SK. 2001. Preliminary field report: Palau 2000 Project, Babeldaob, Republic of Palau [typescript on file with the author]. Tromsø: Tromsø University $\mathrm{Mu}$ seum, Norway, and The Centre for Archaeological Research at the Australian National University Canberra. 


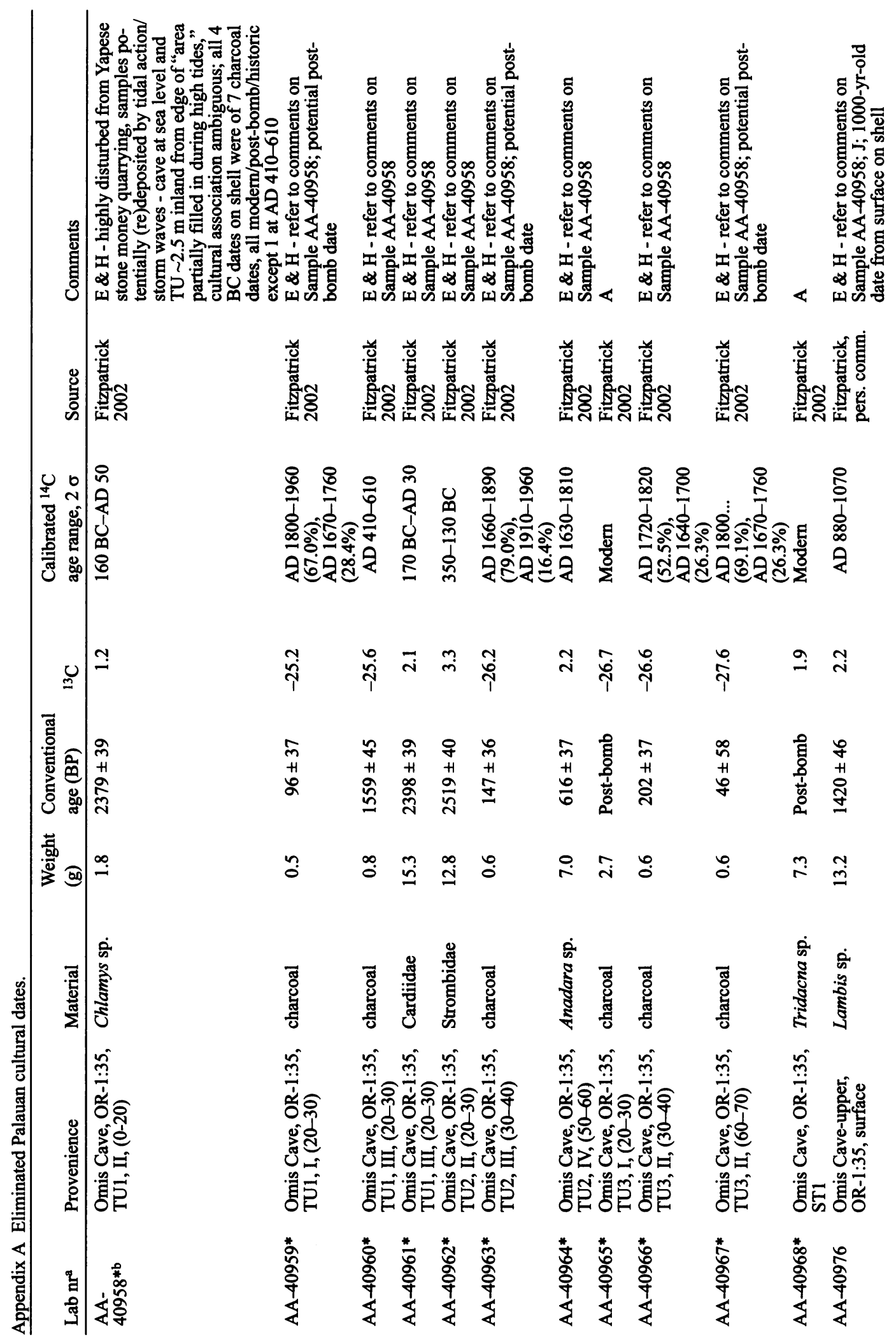




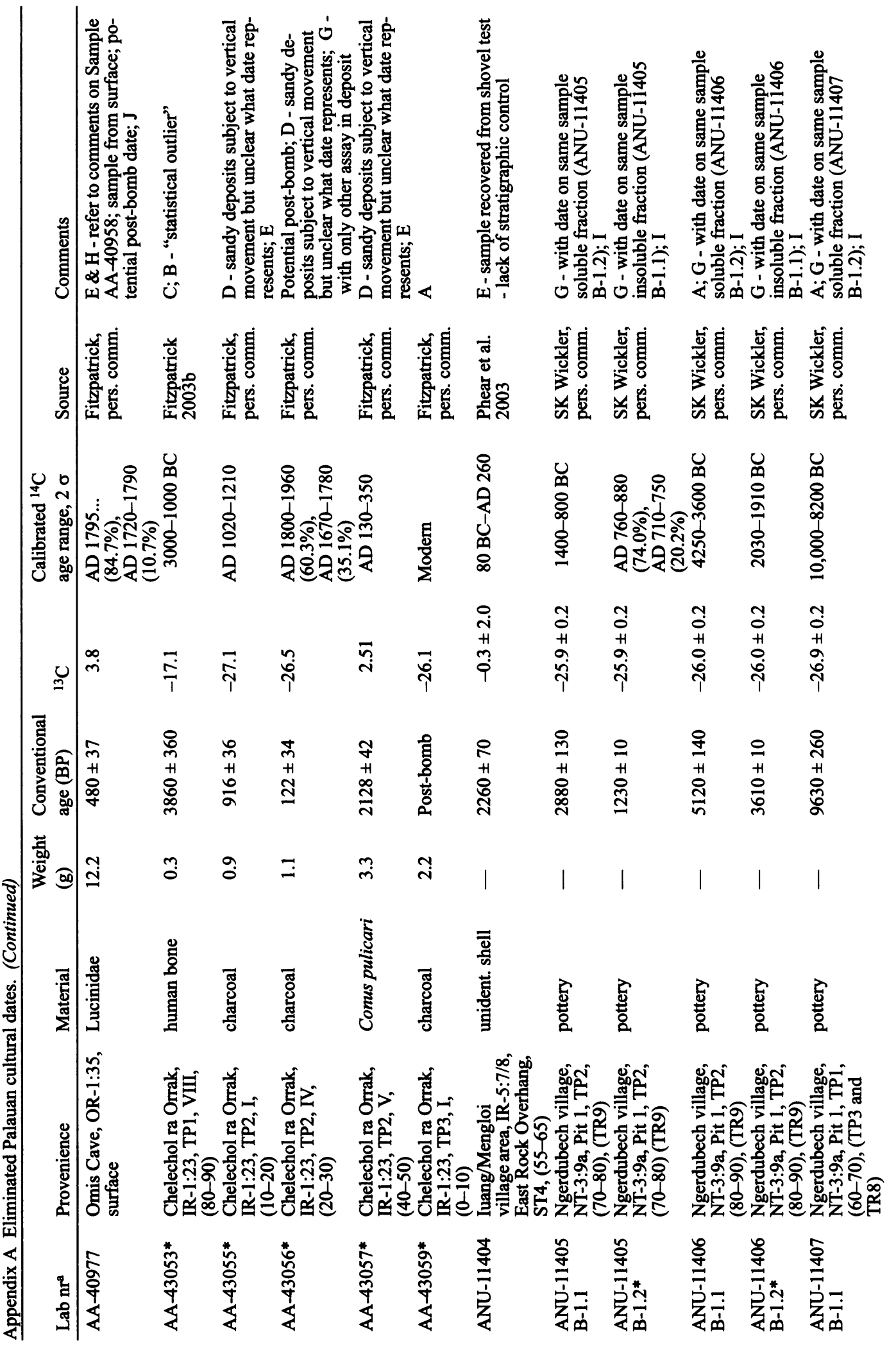




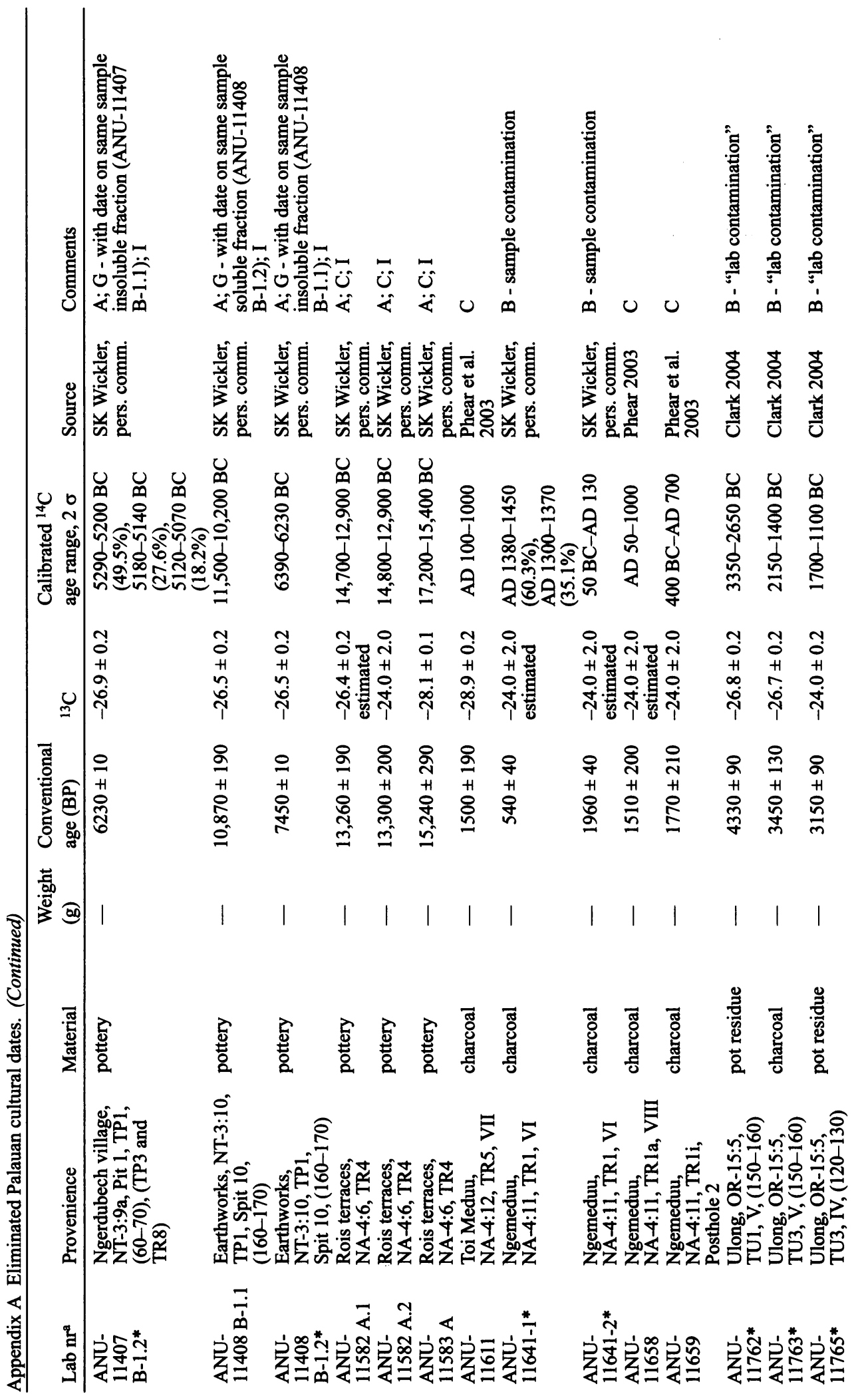




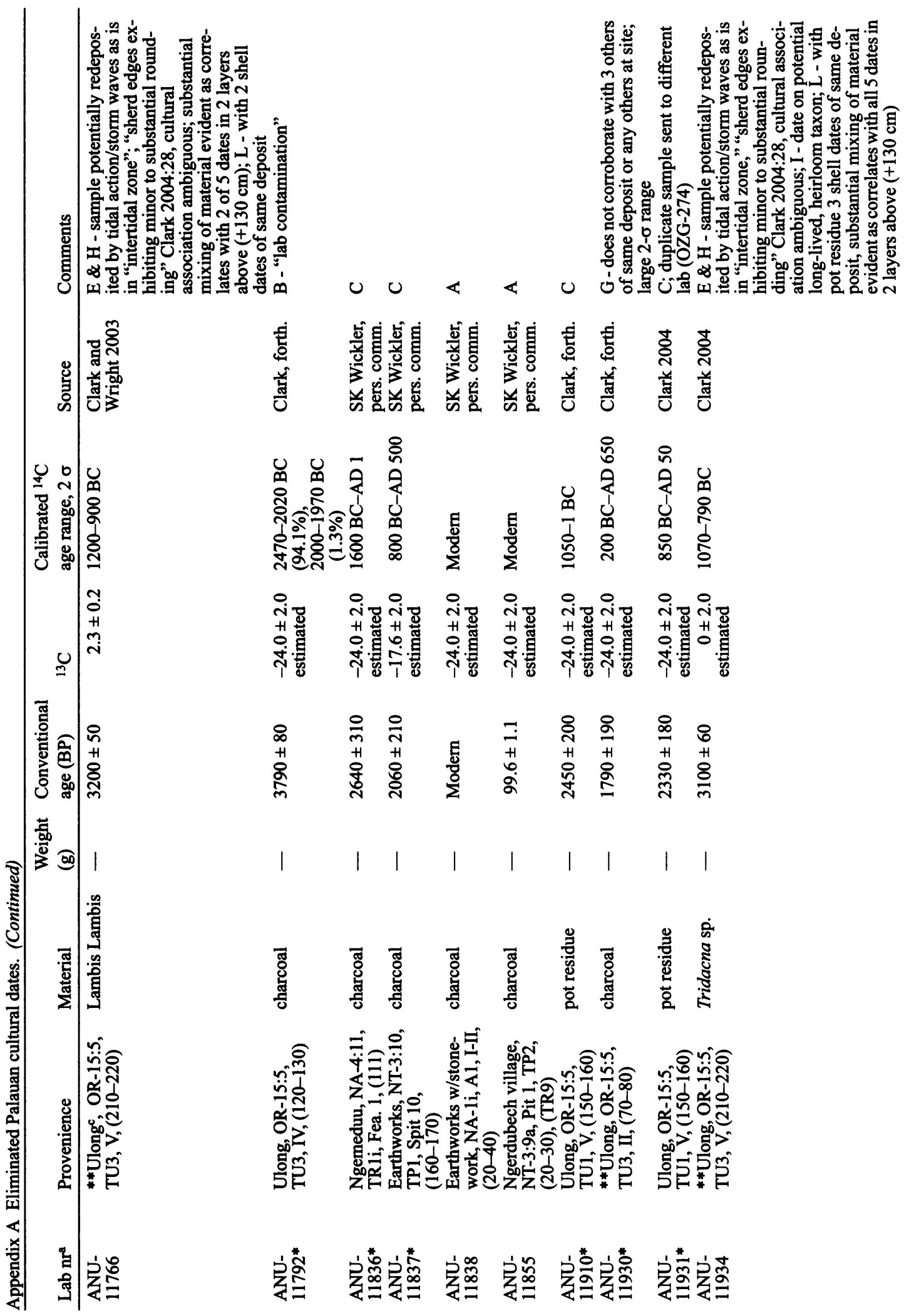




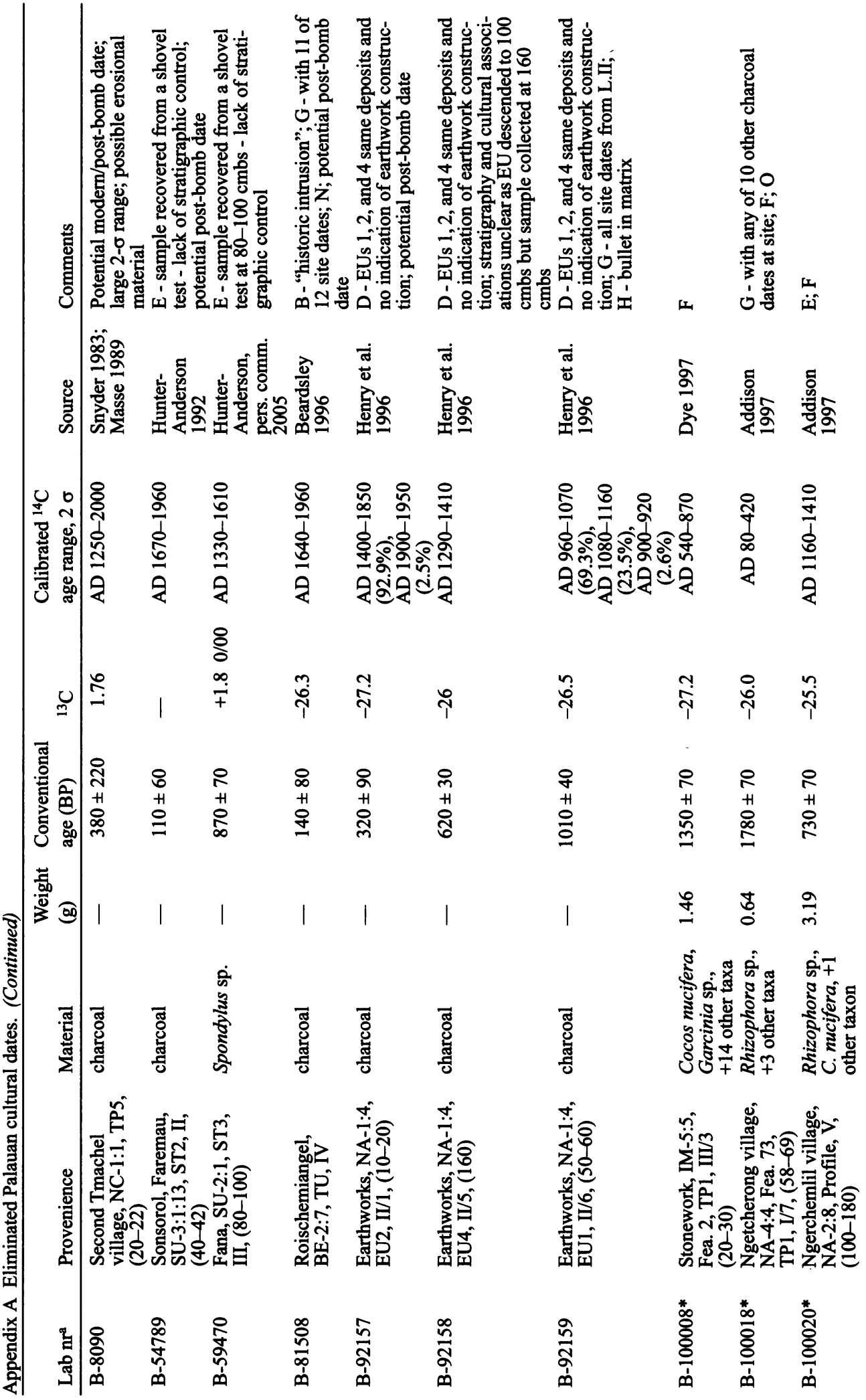




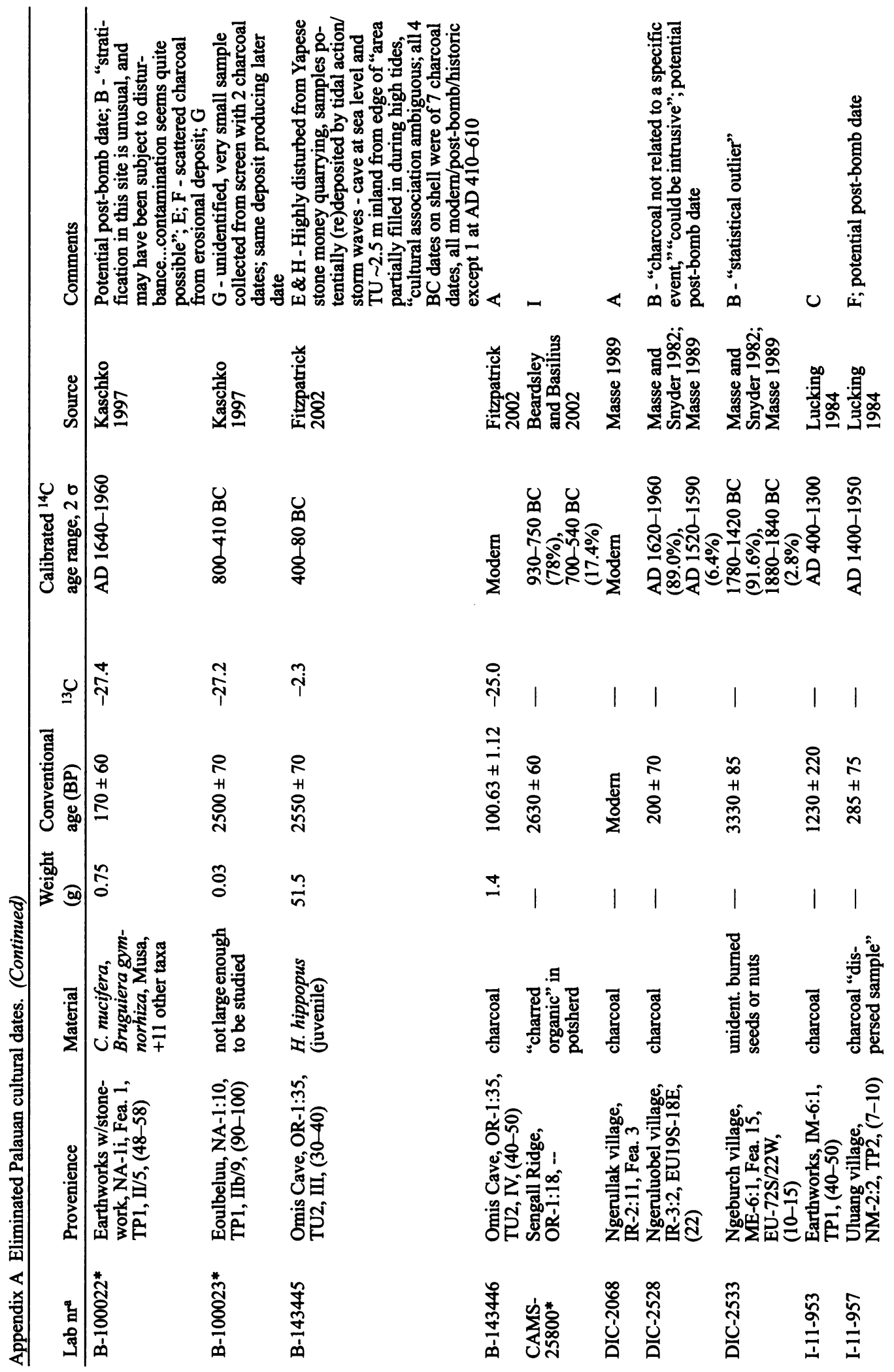




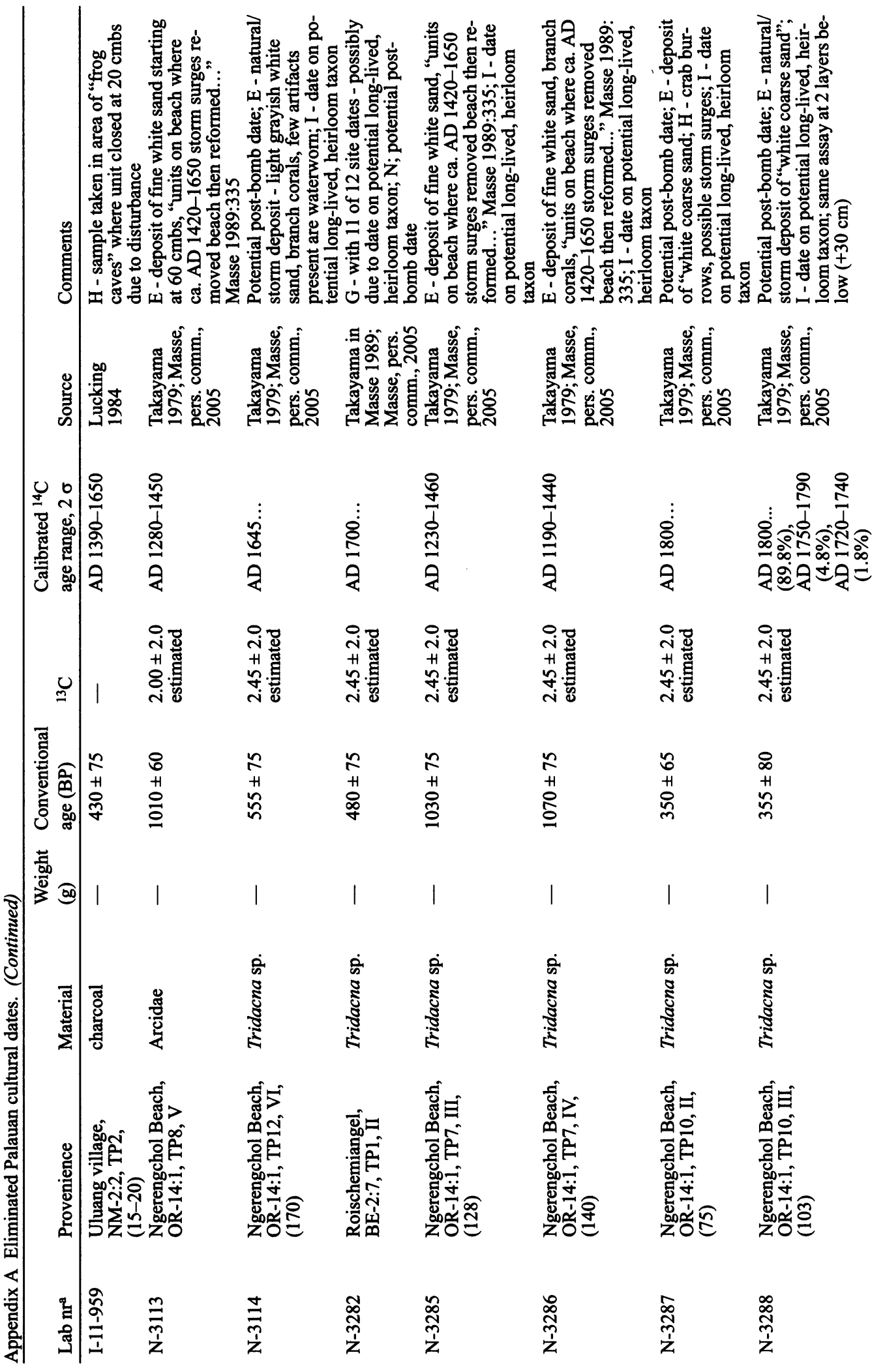




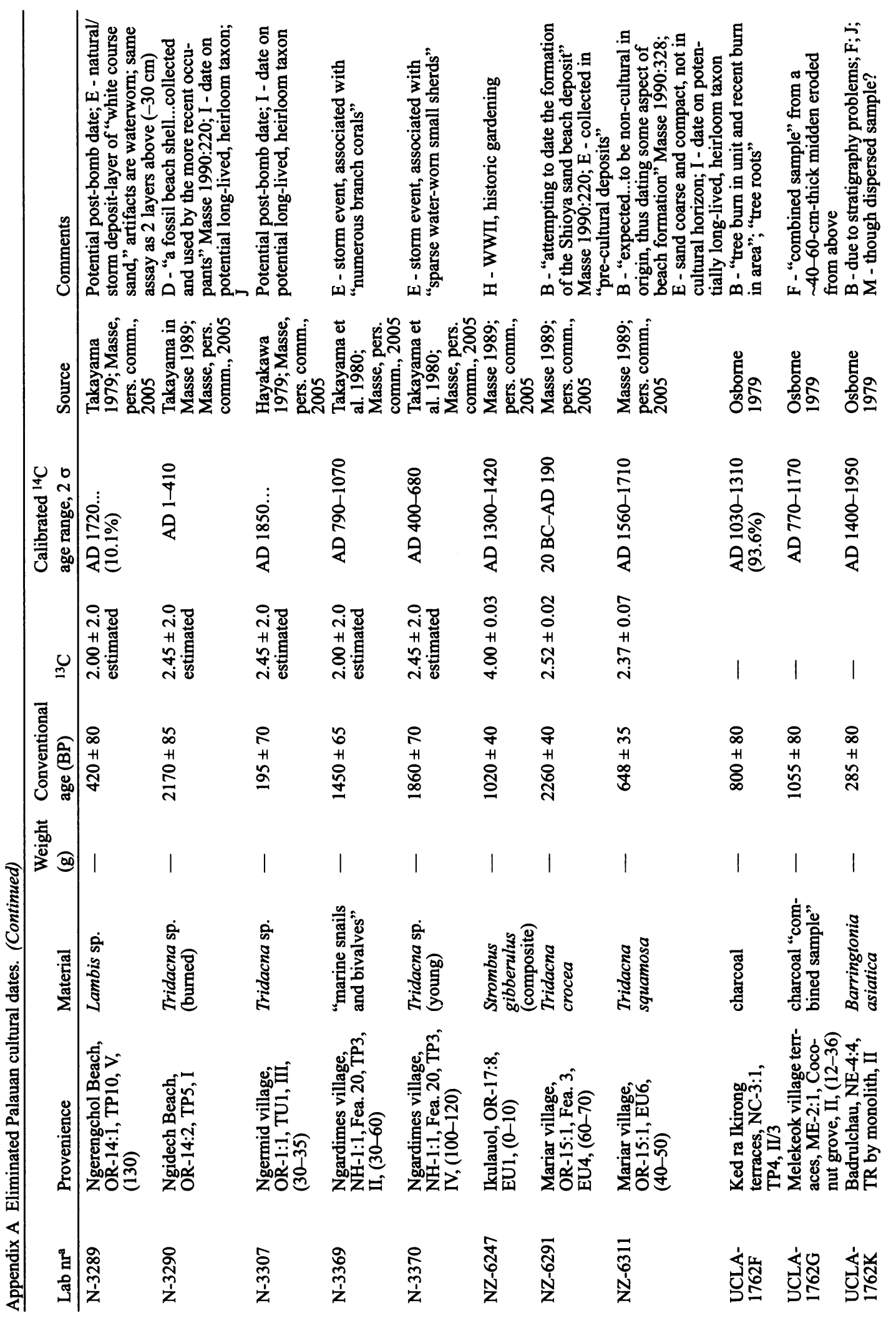




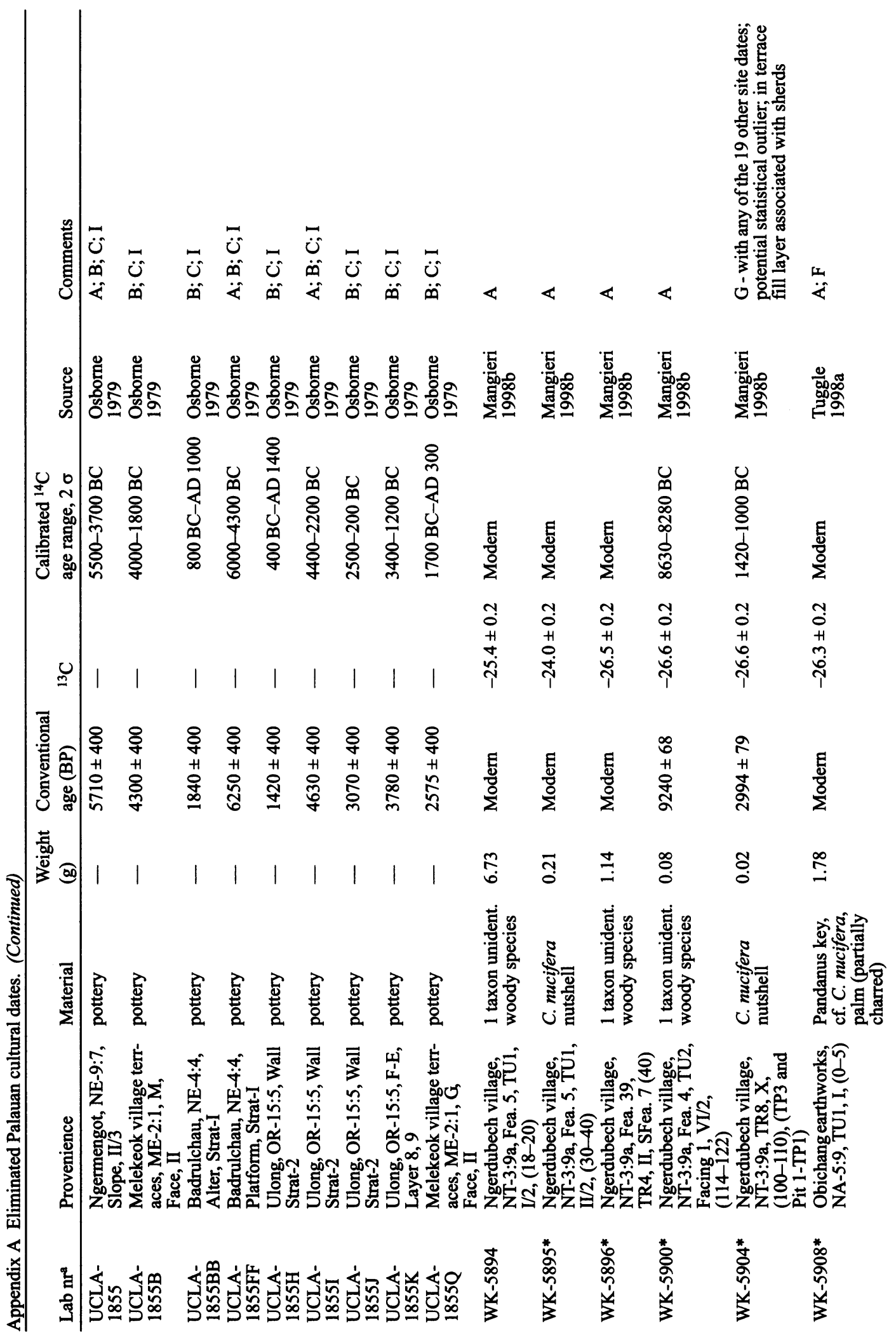




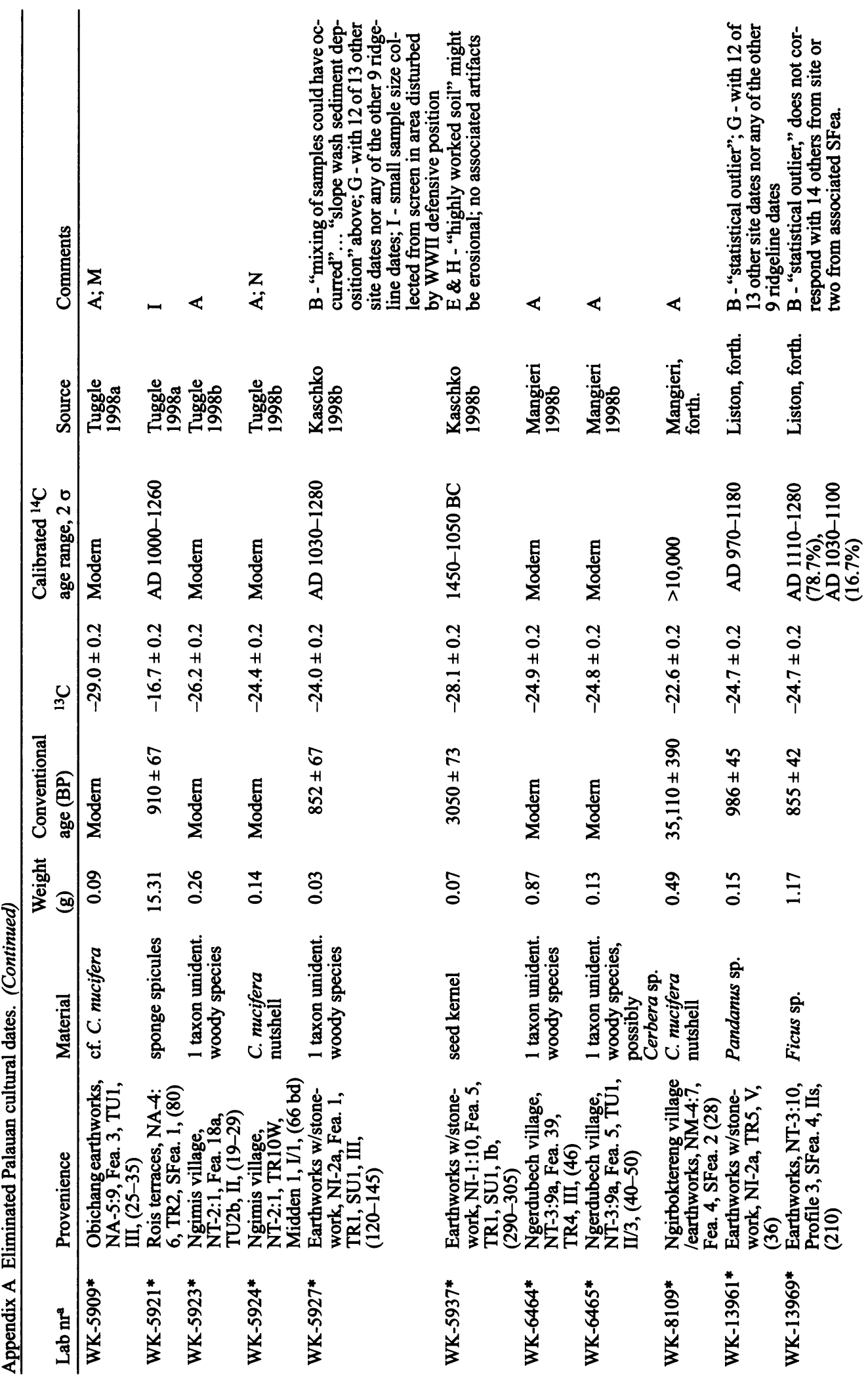




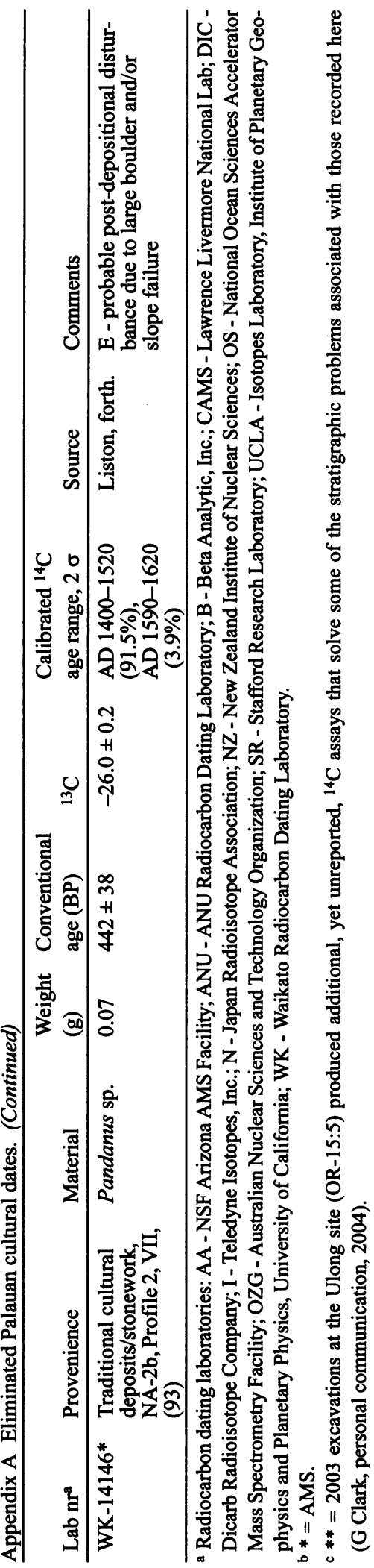




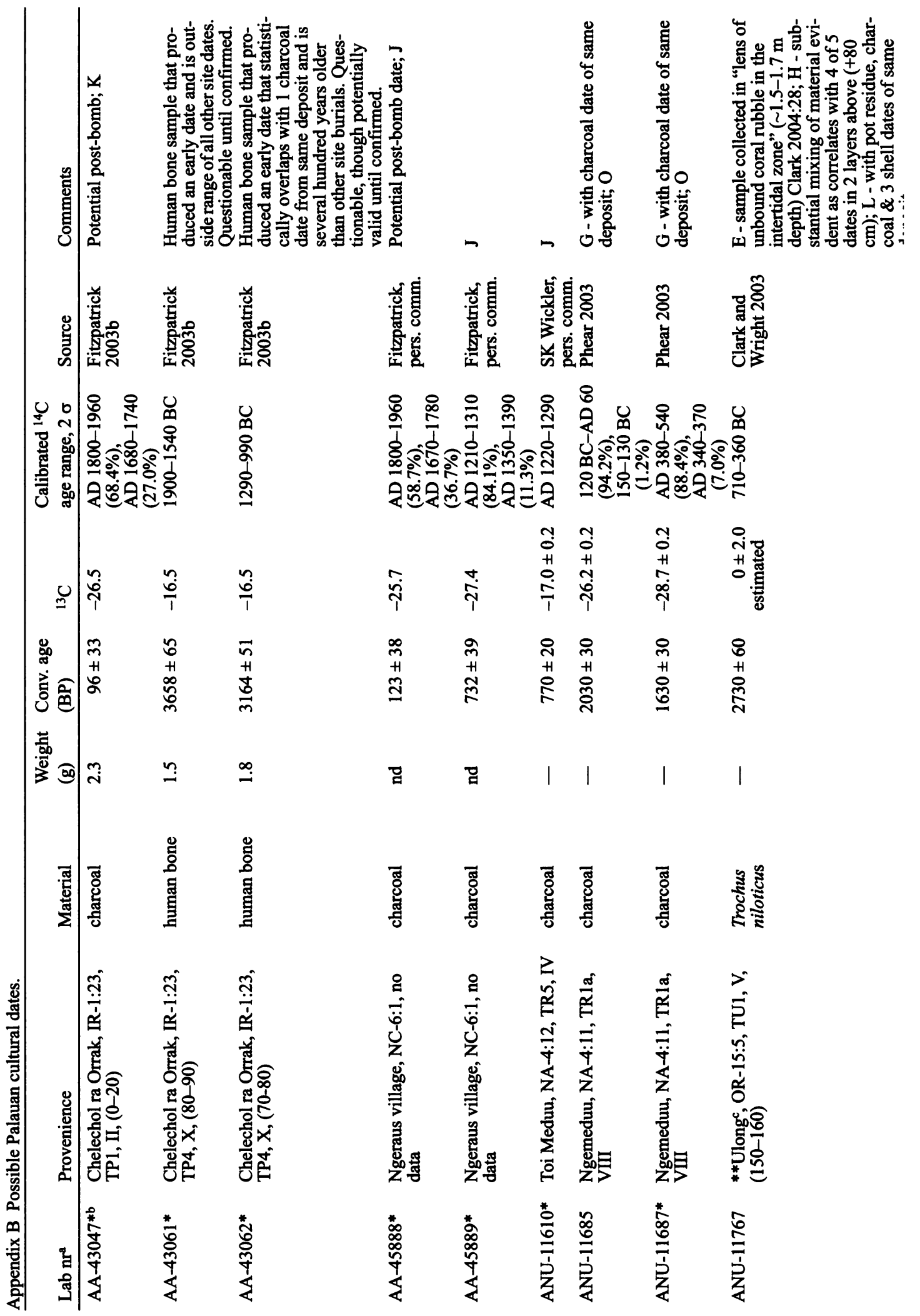




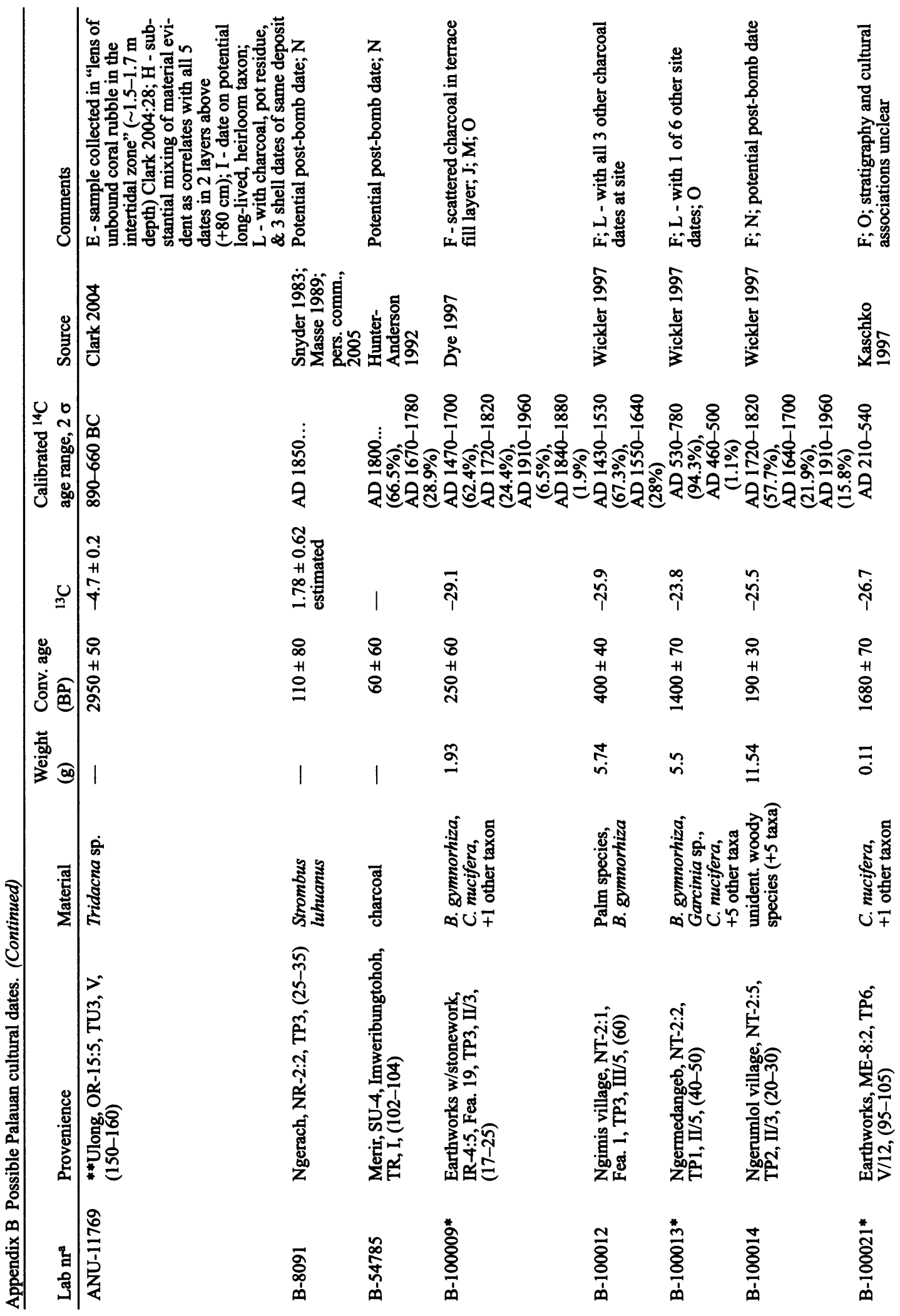




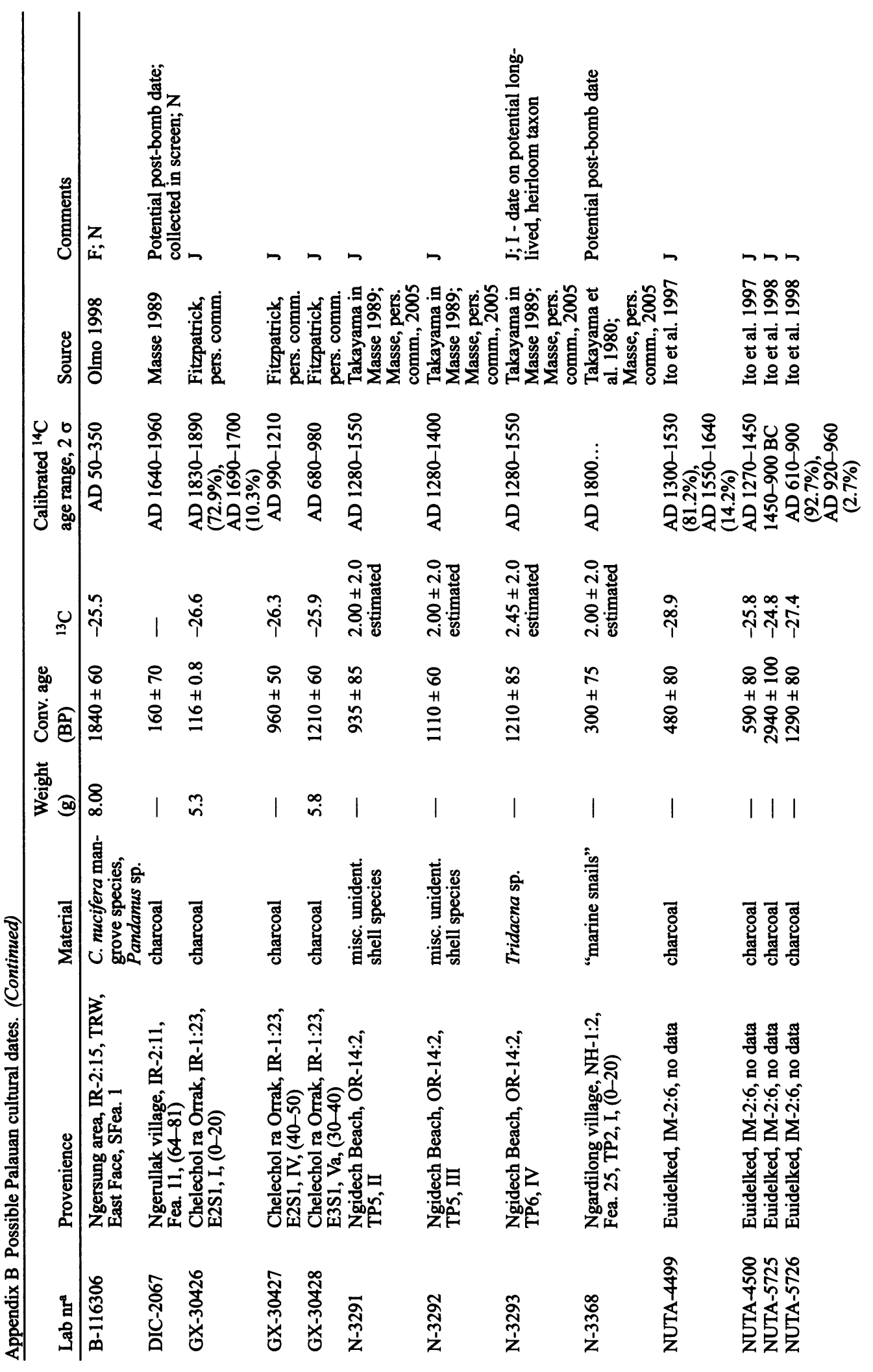




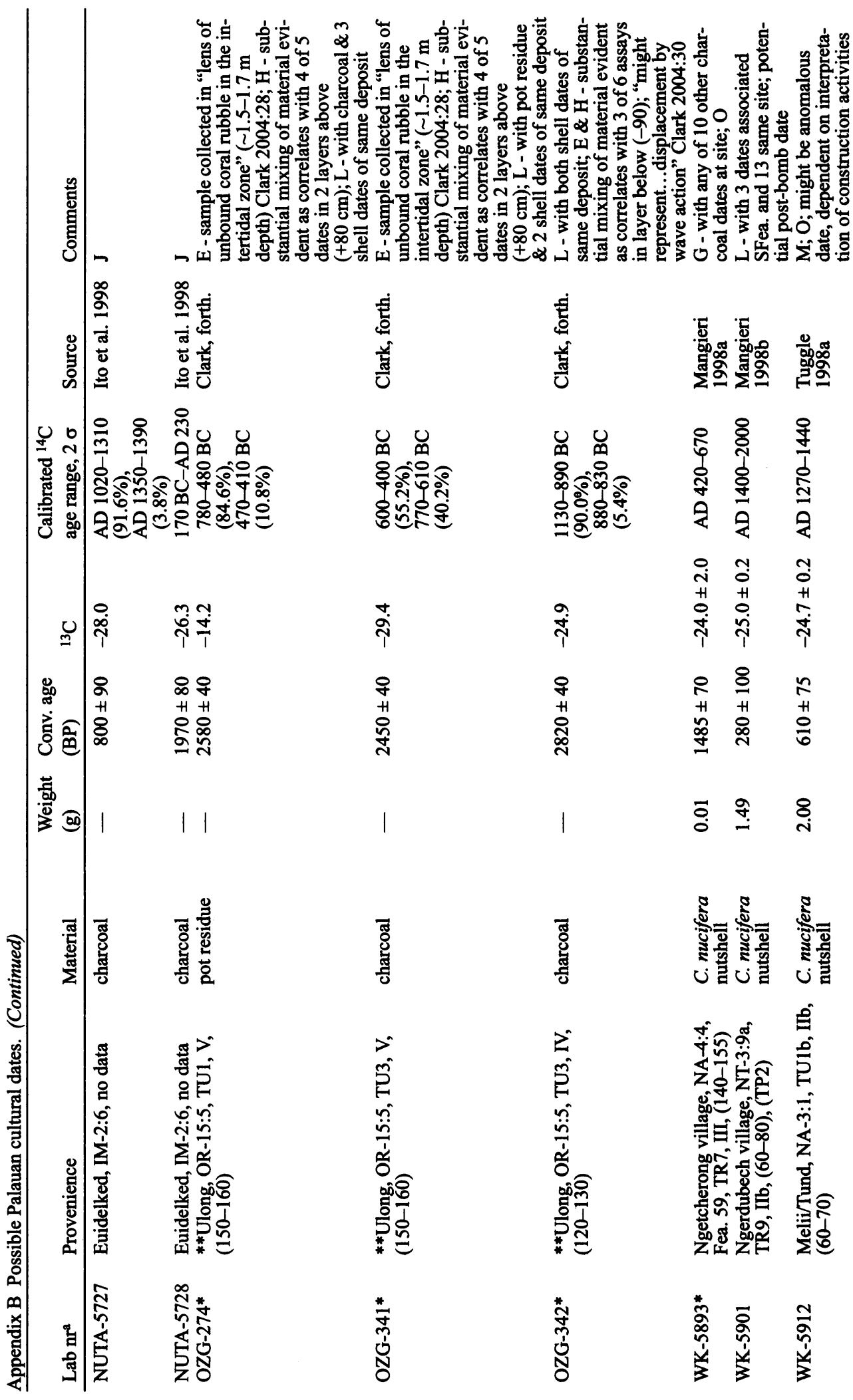




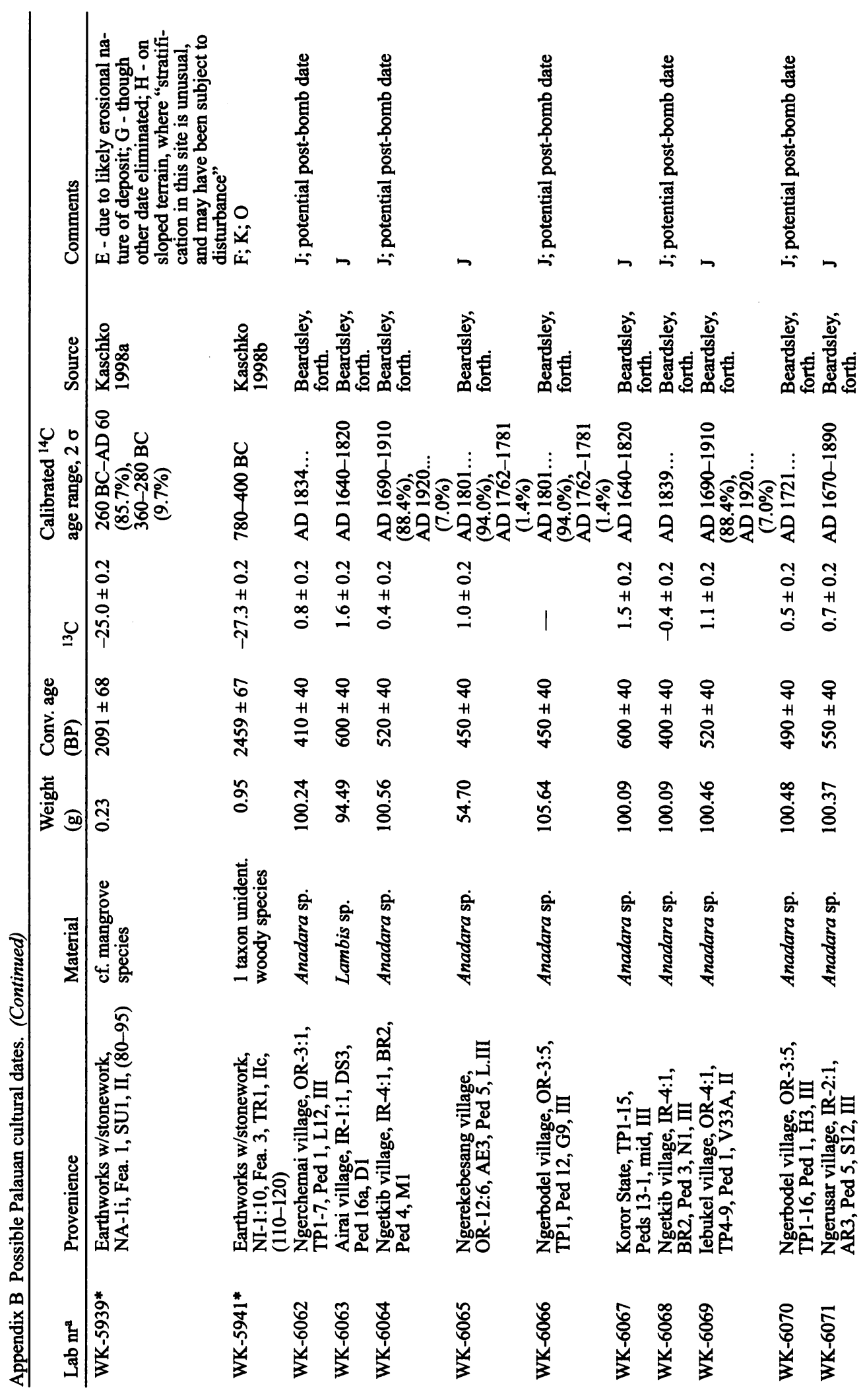




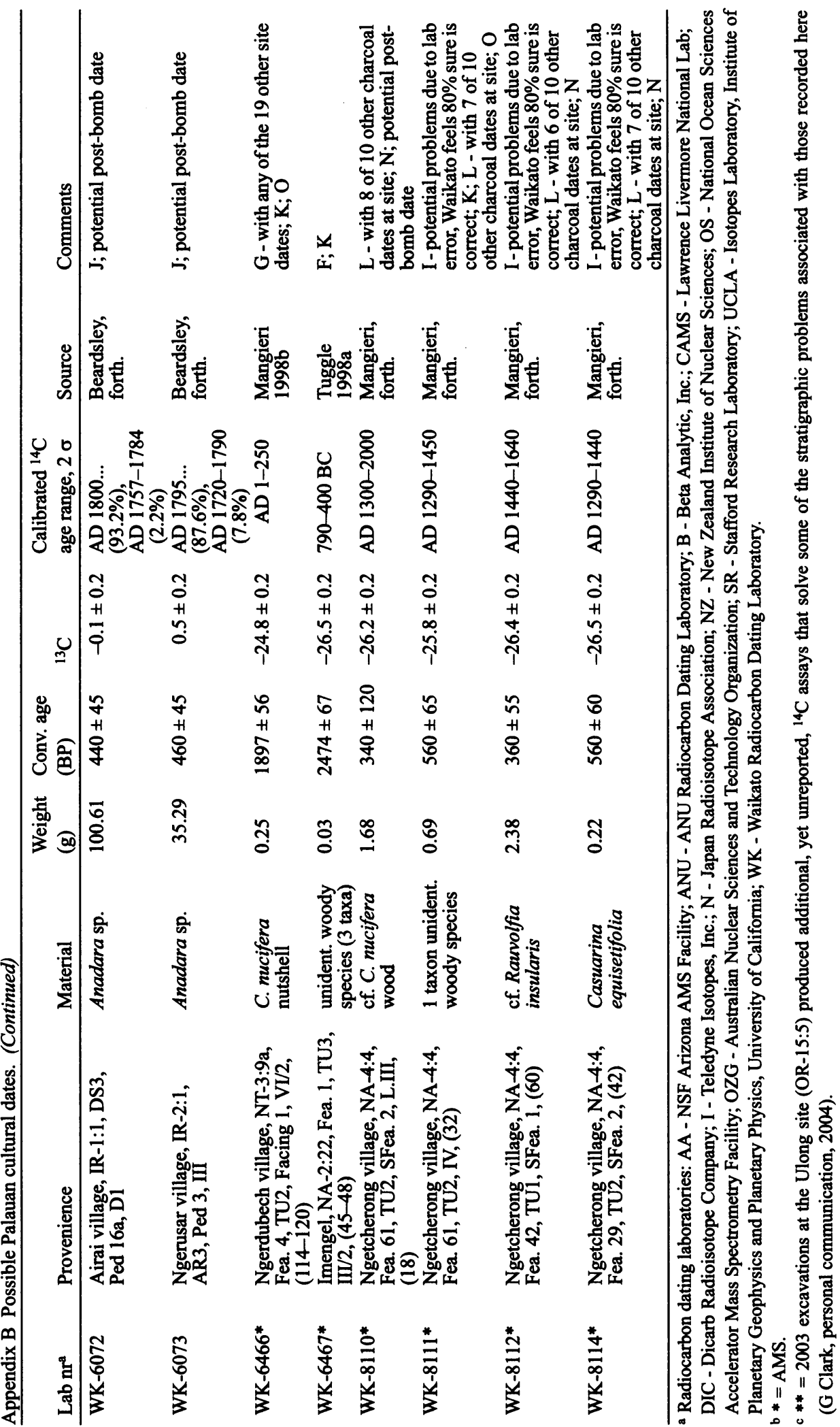




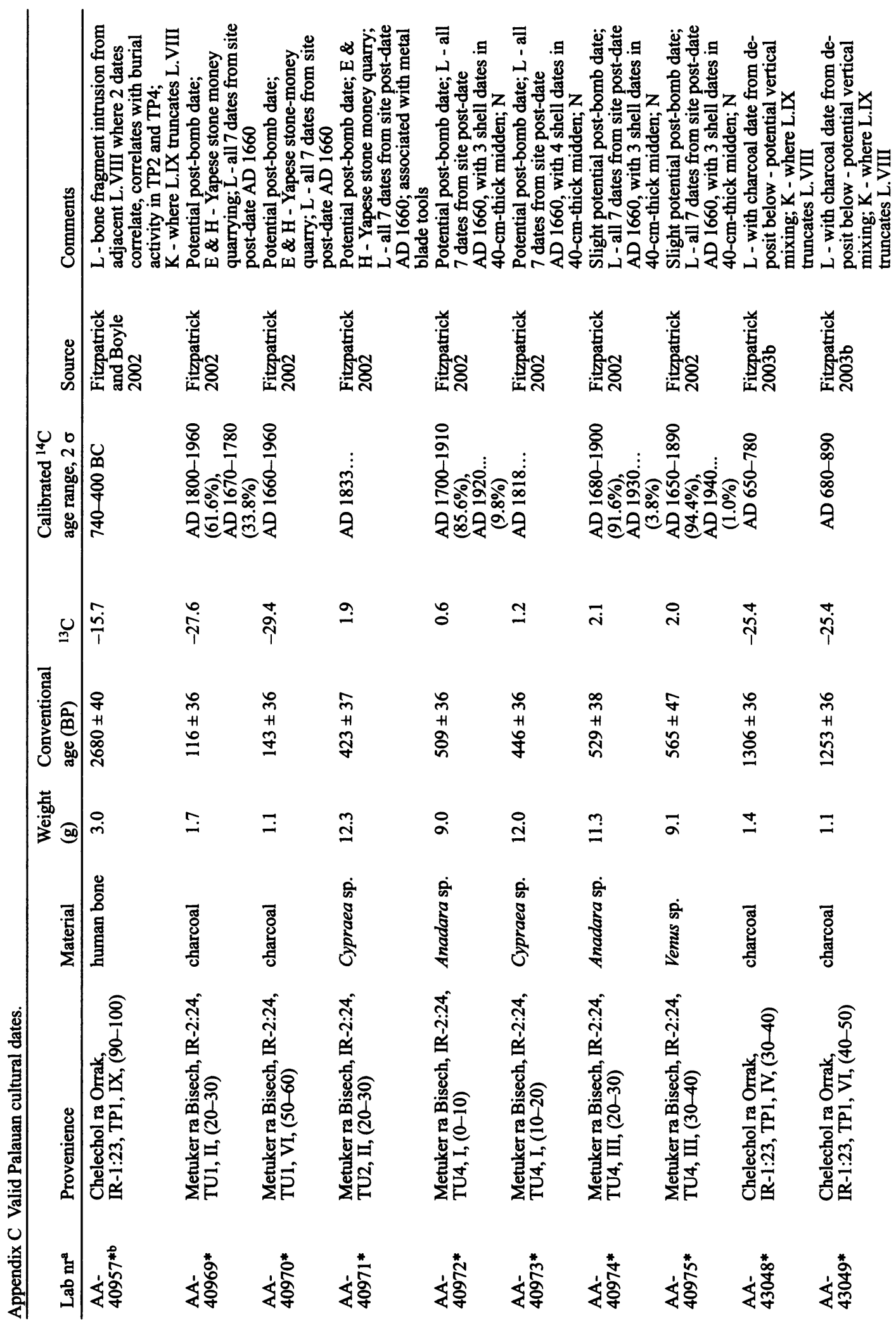




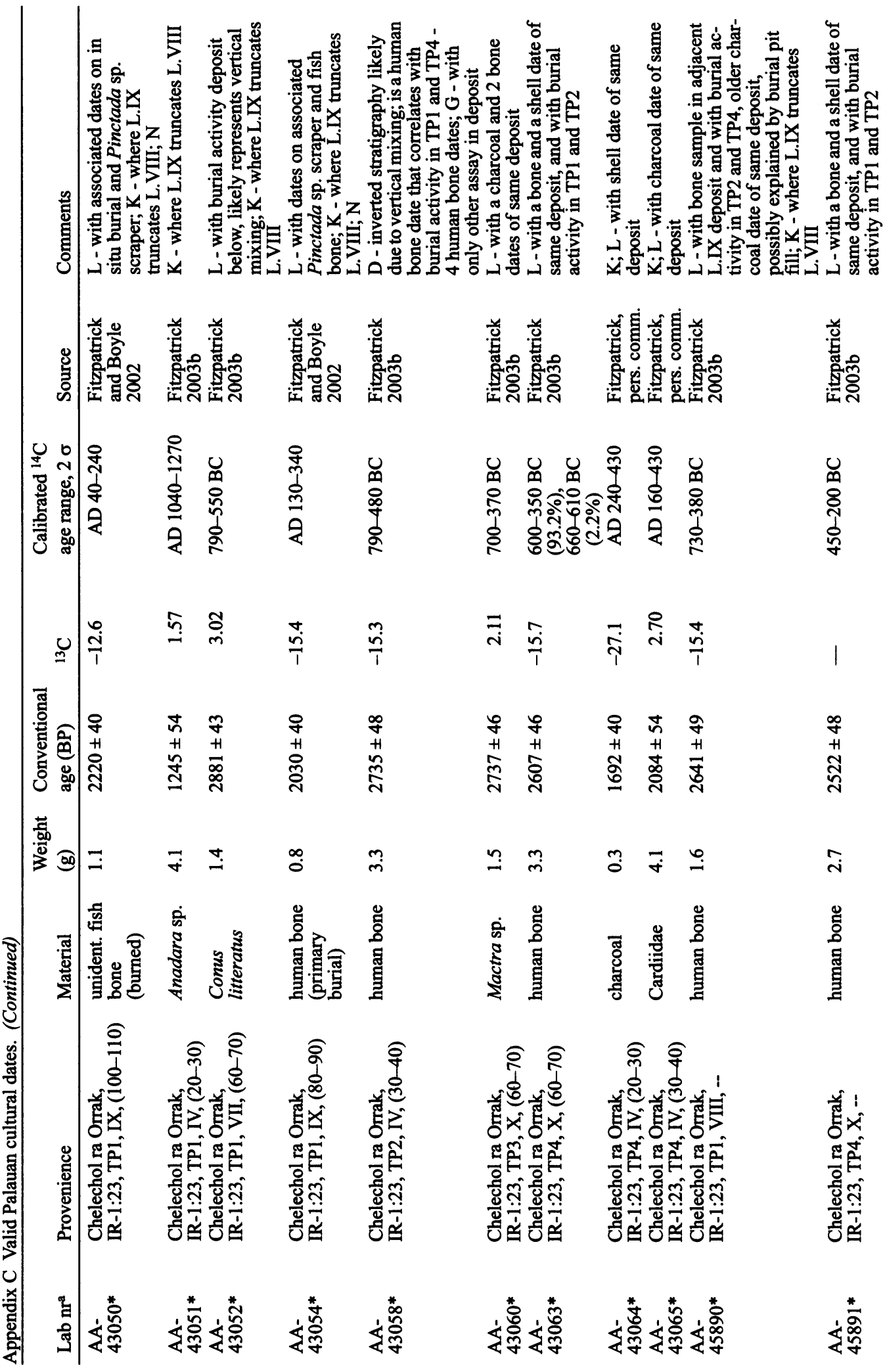




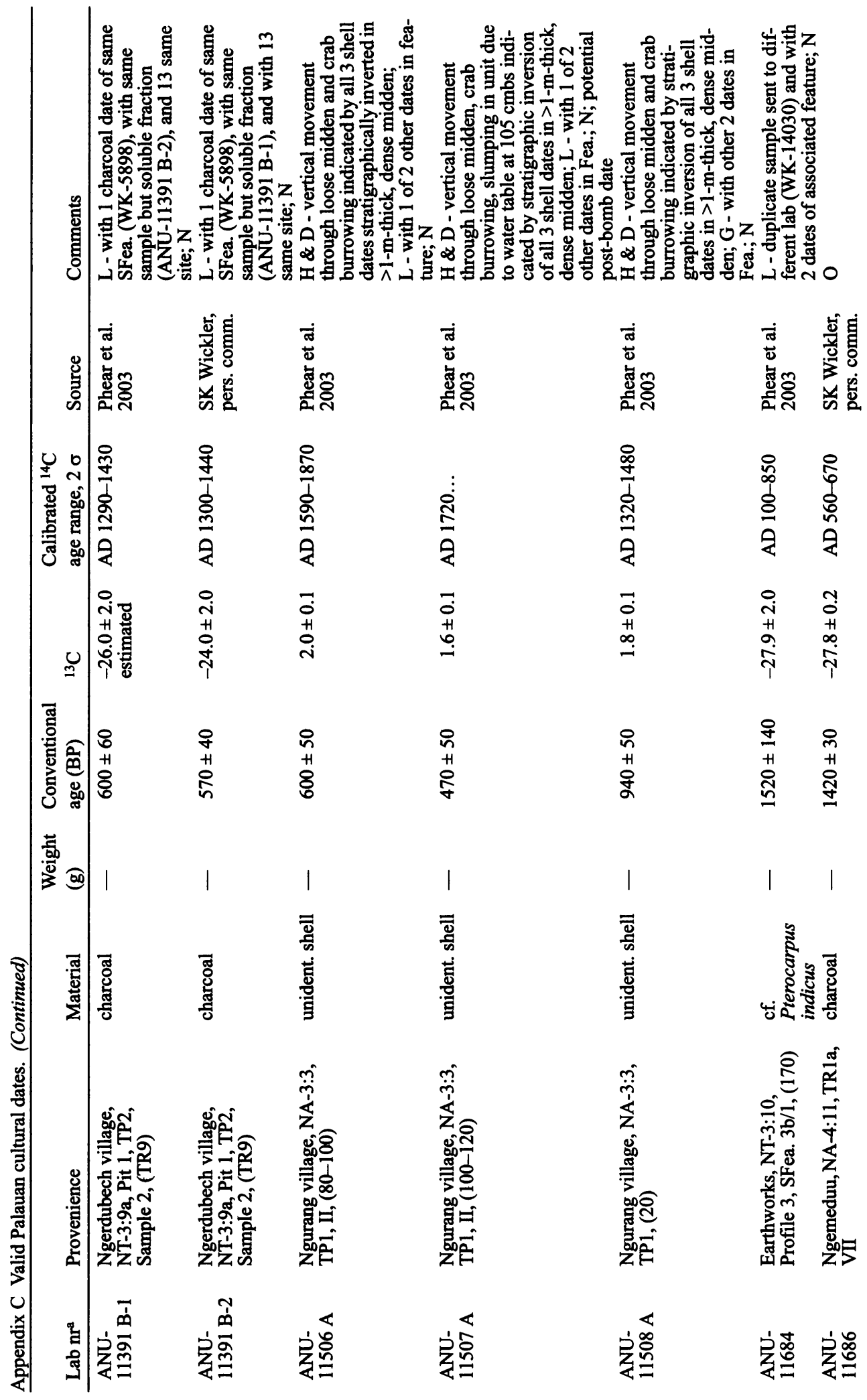




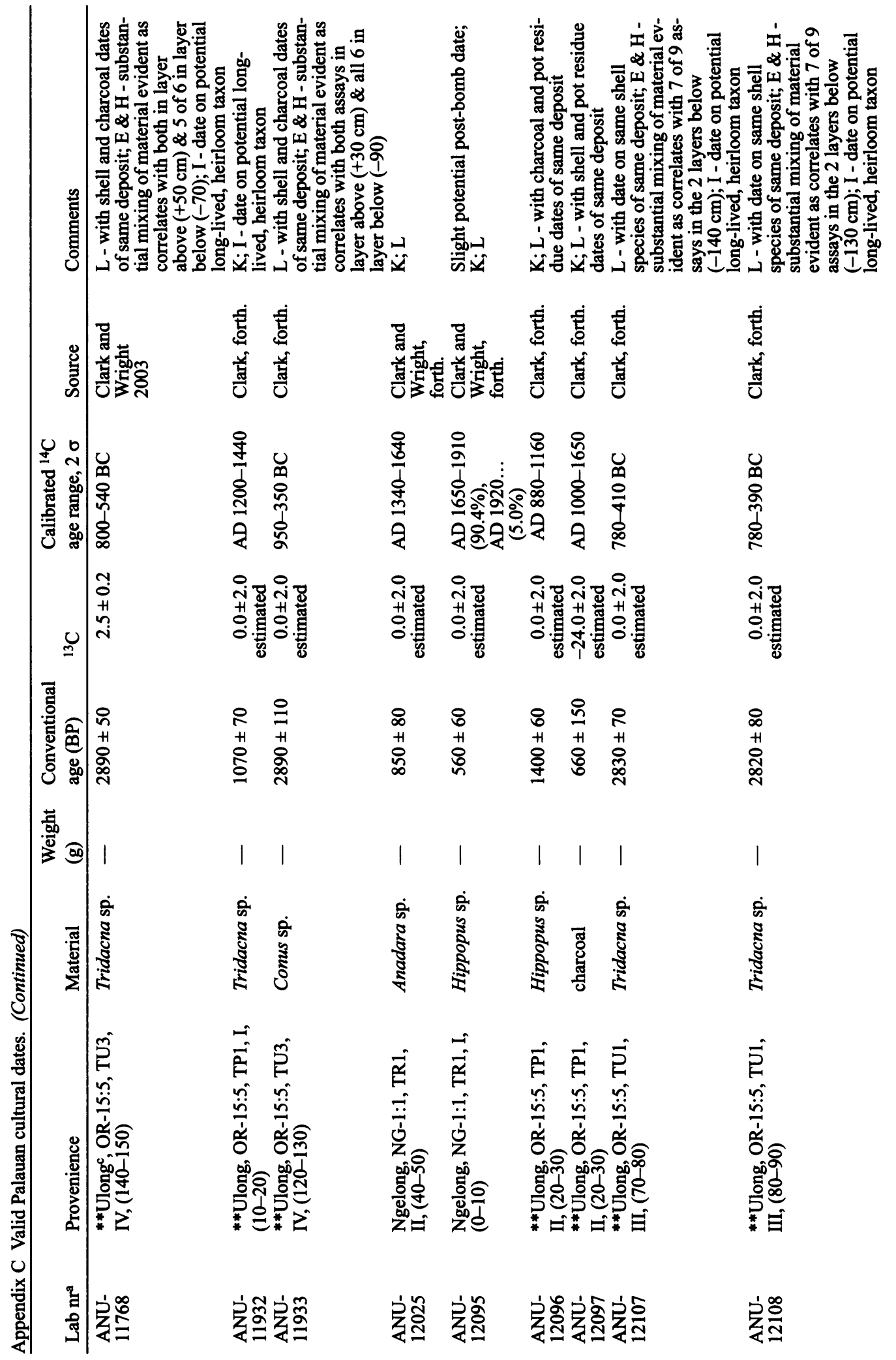




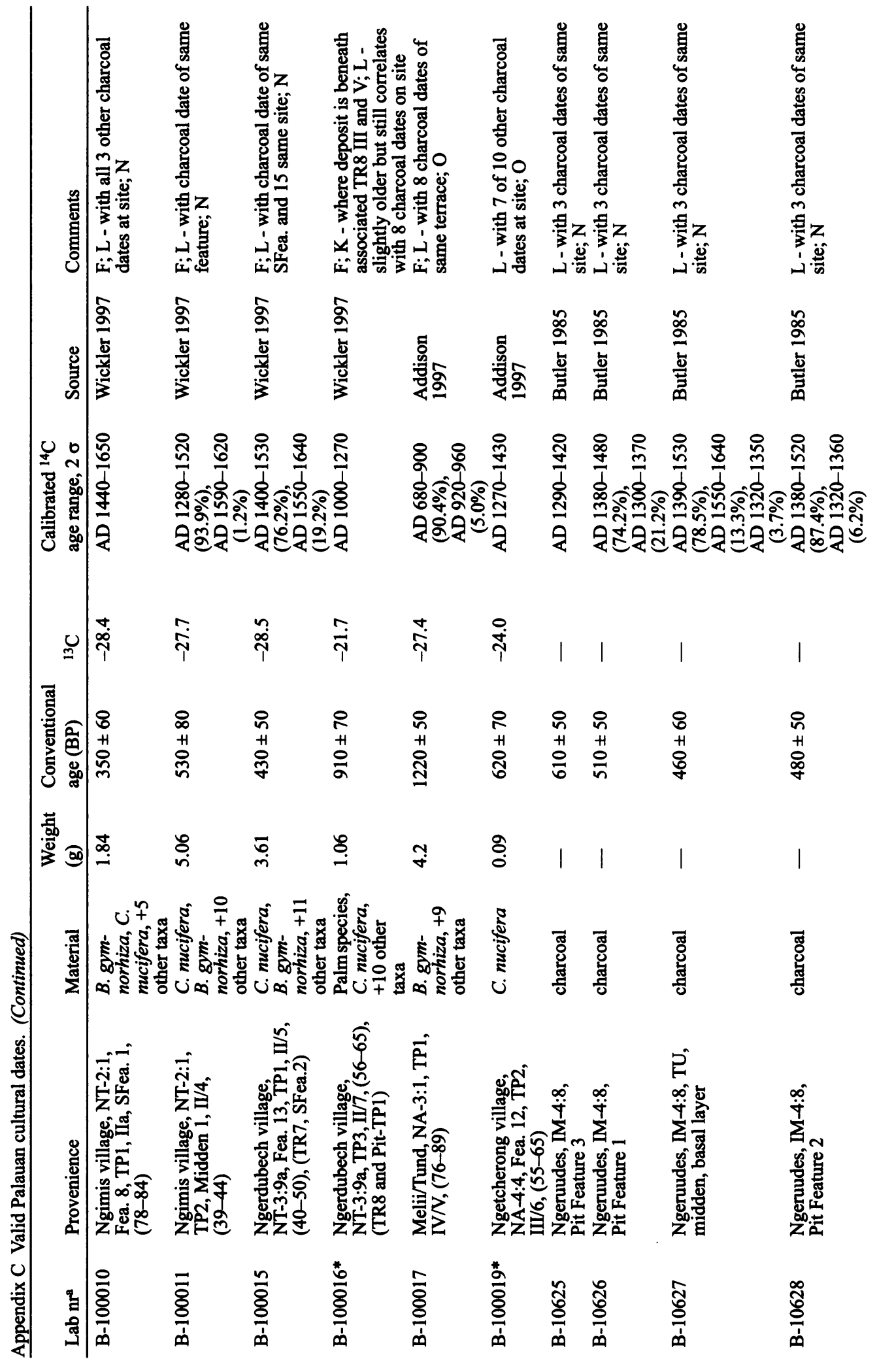




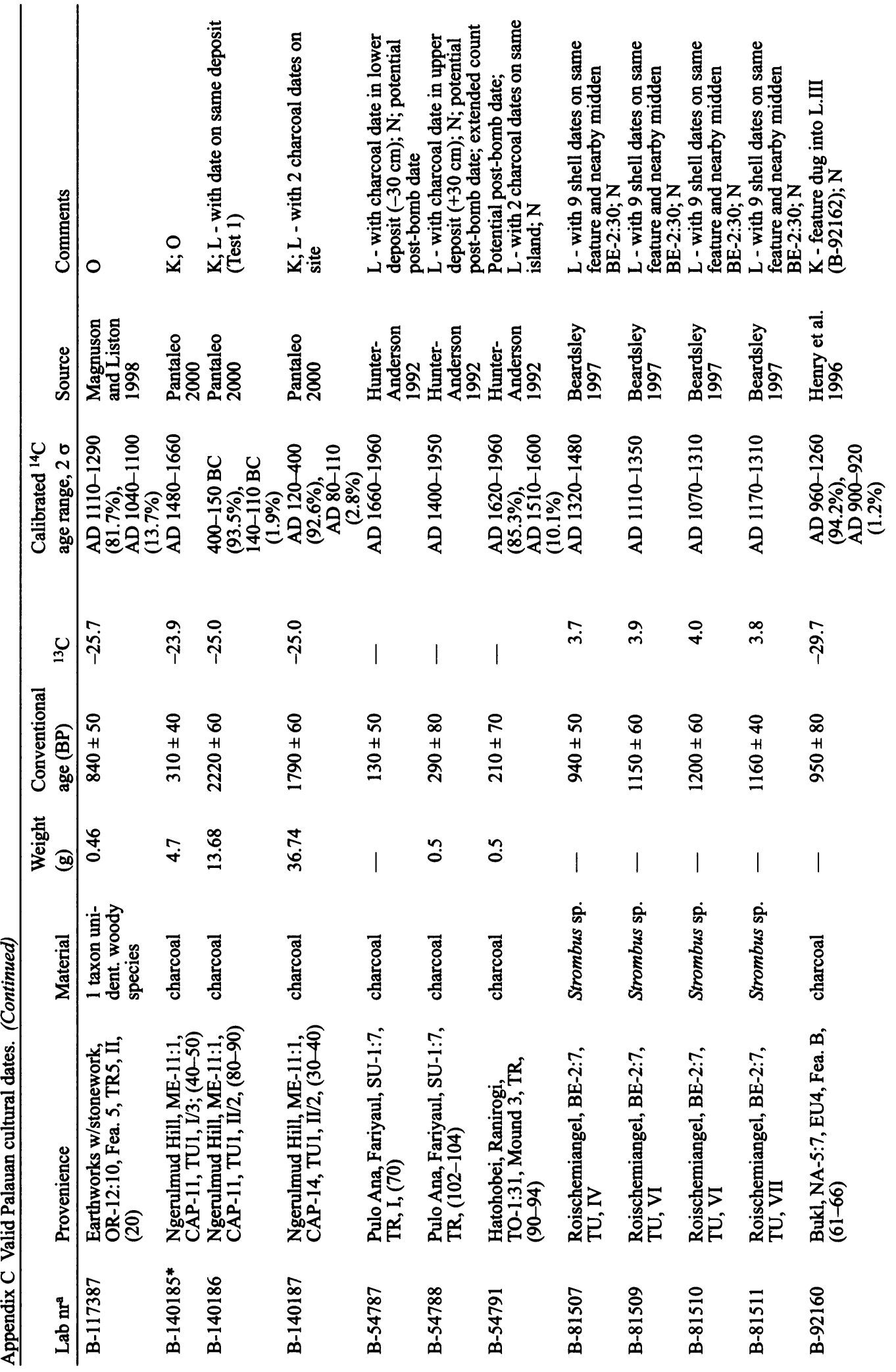




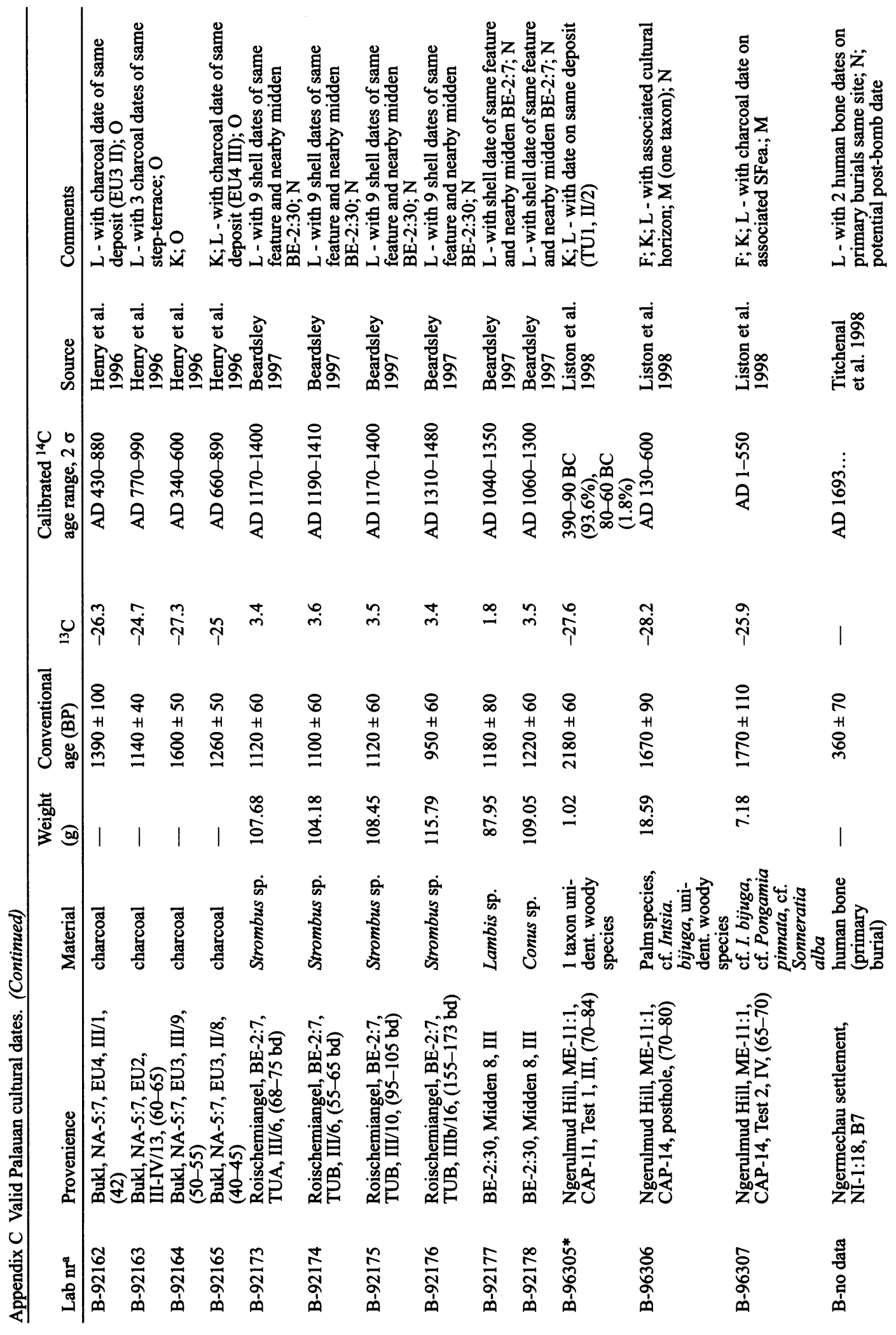




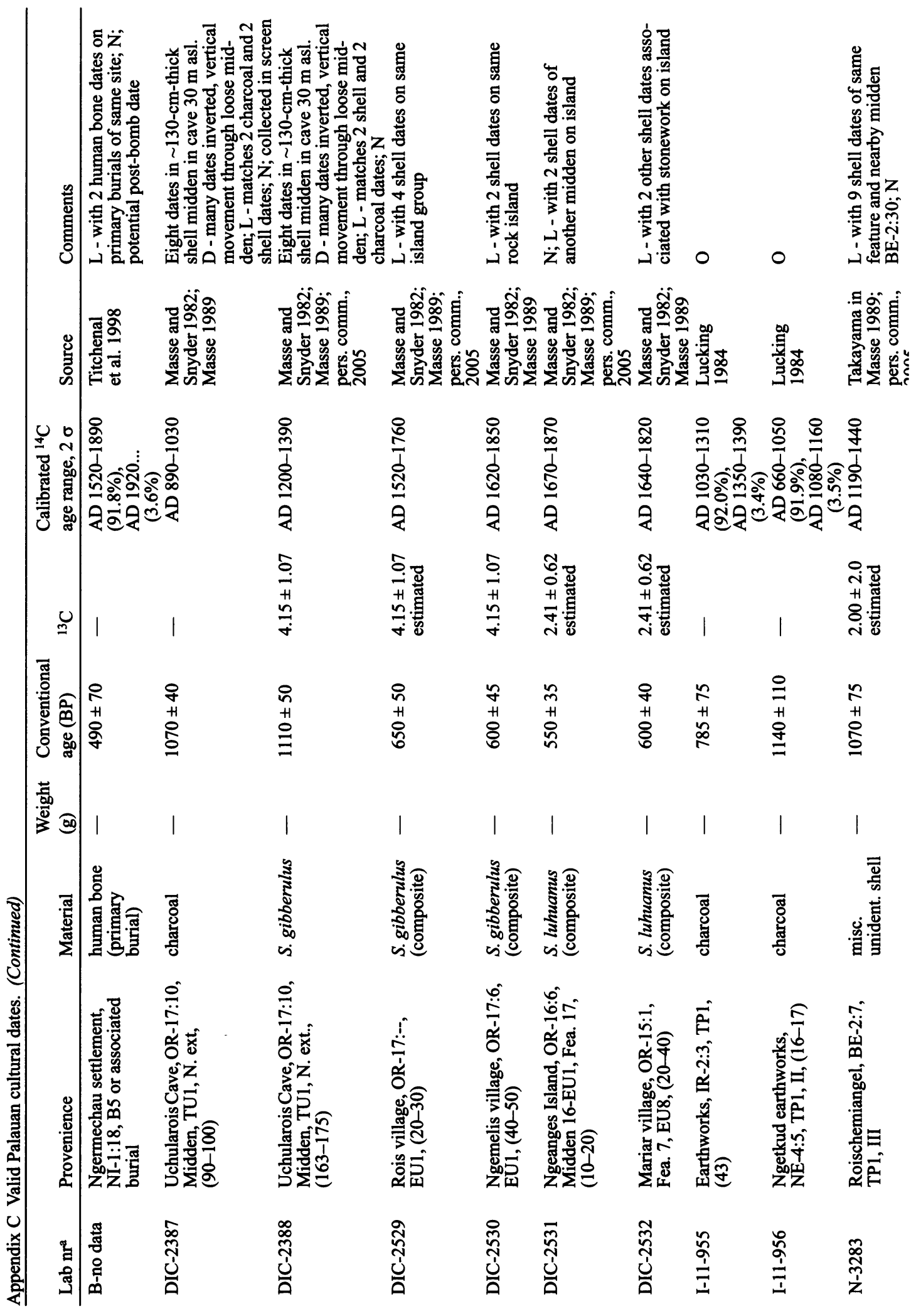




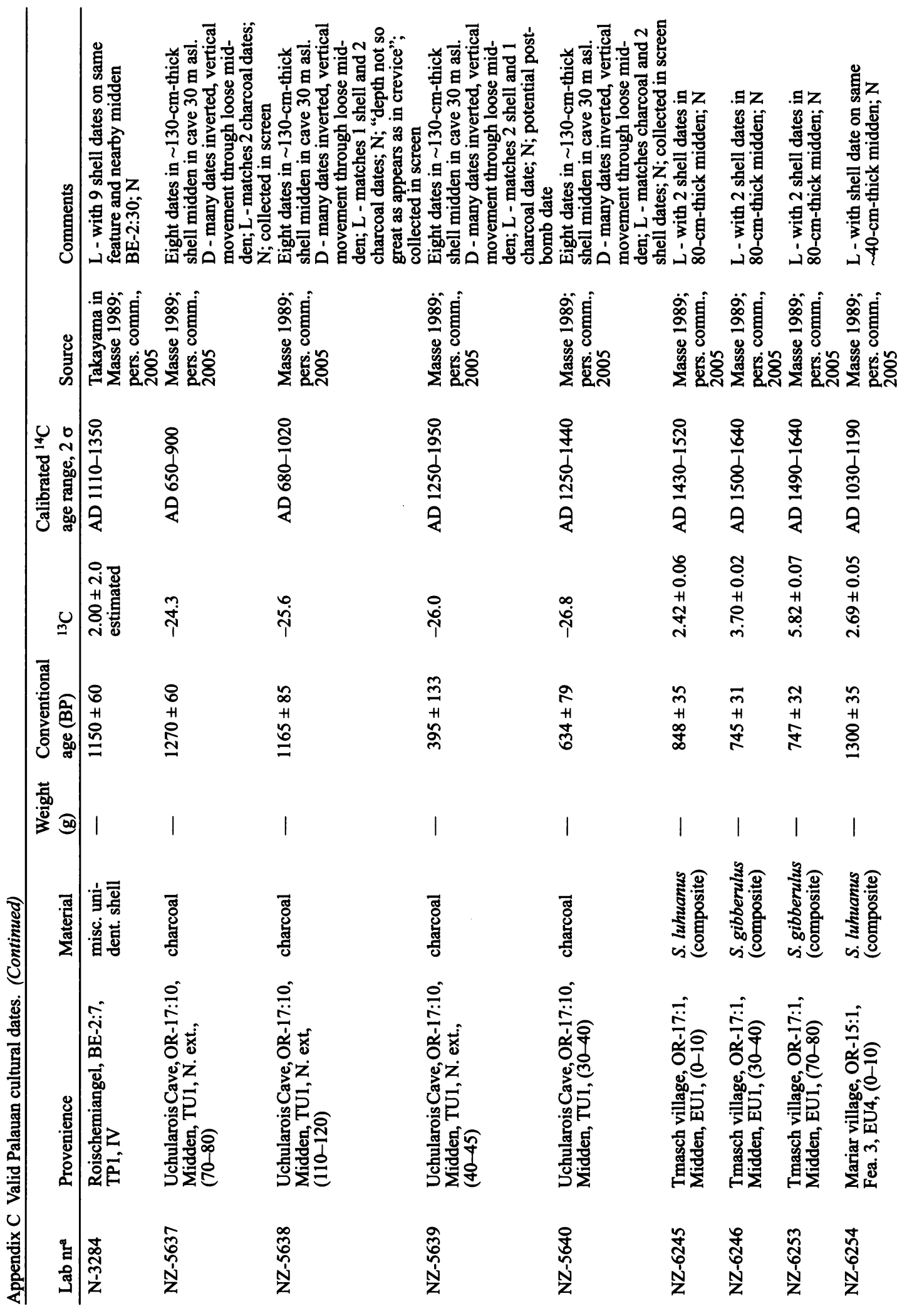




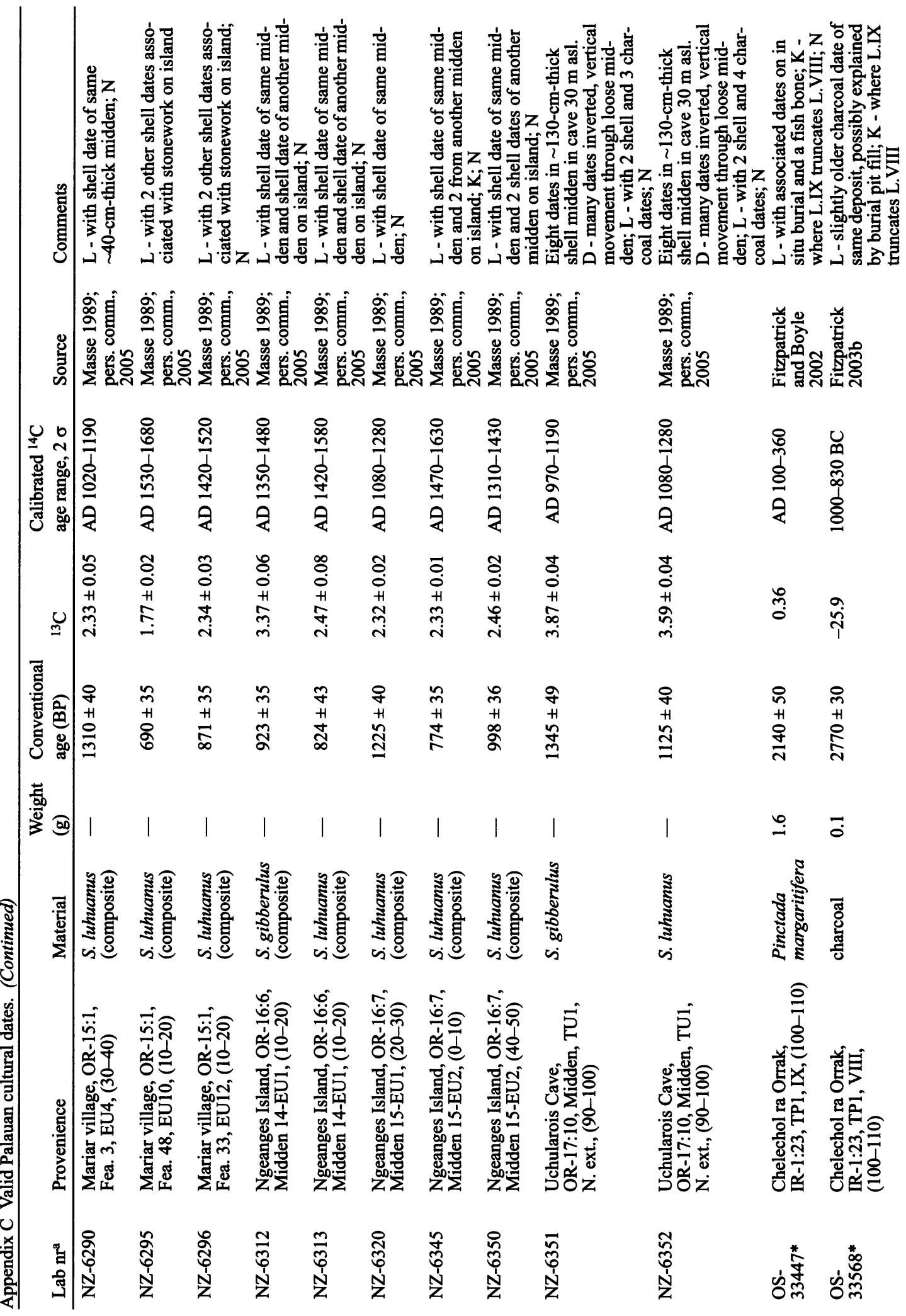




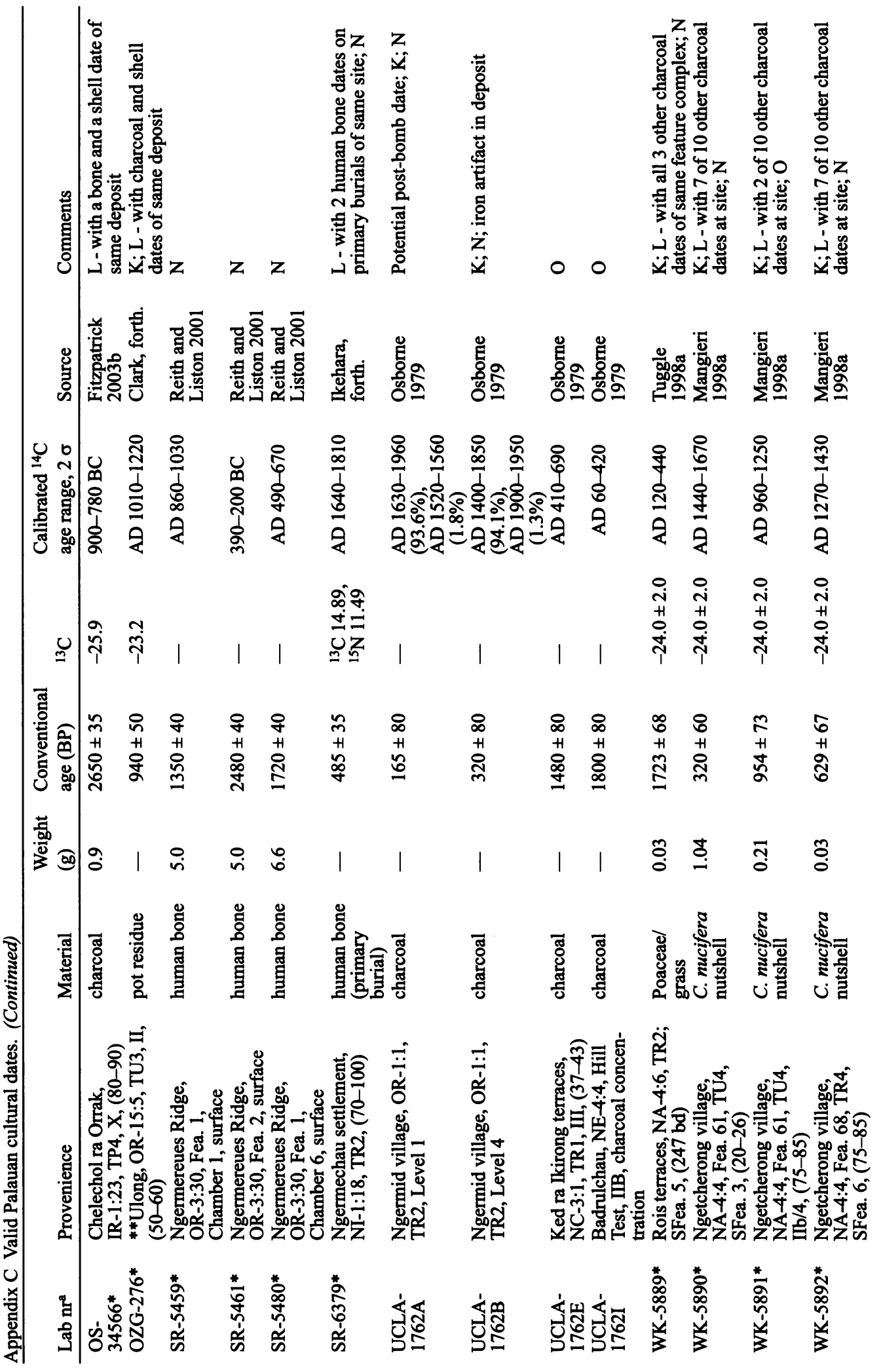




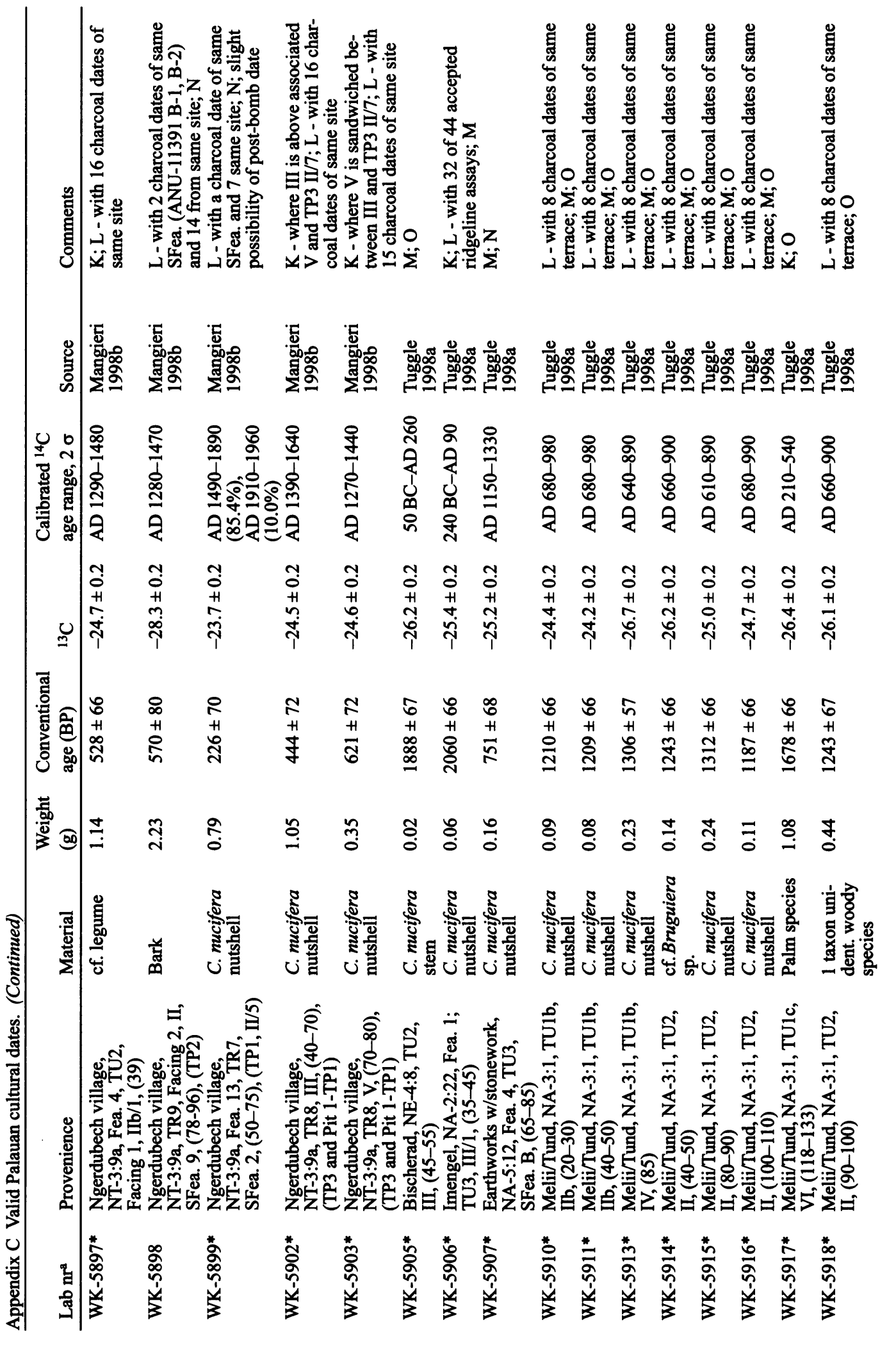




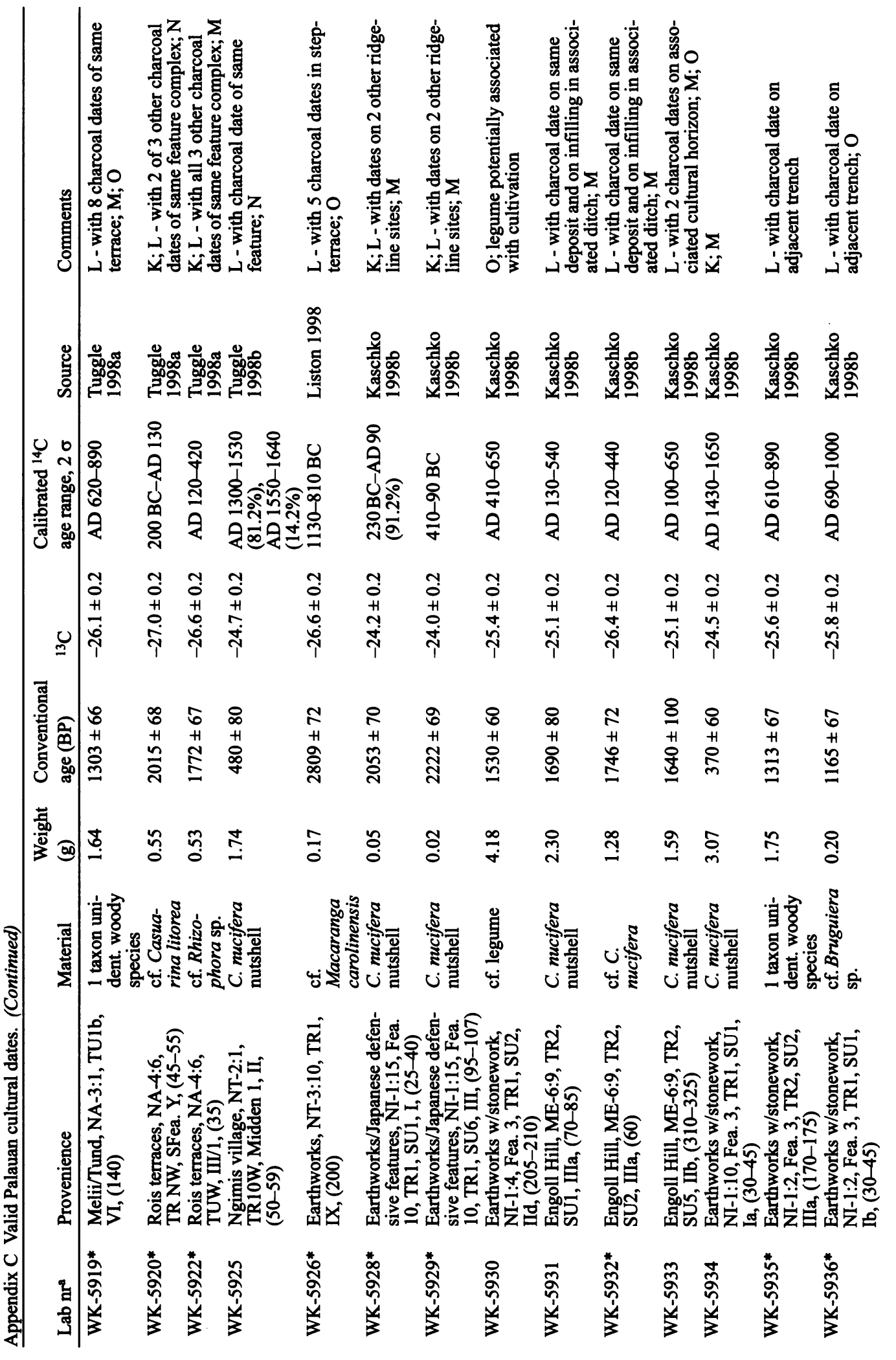




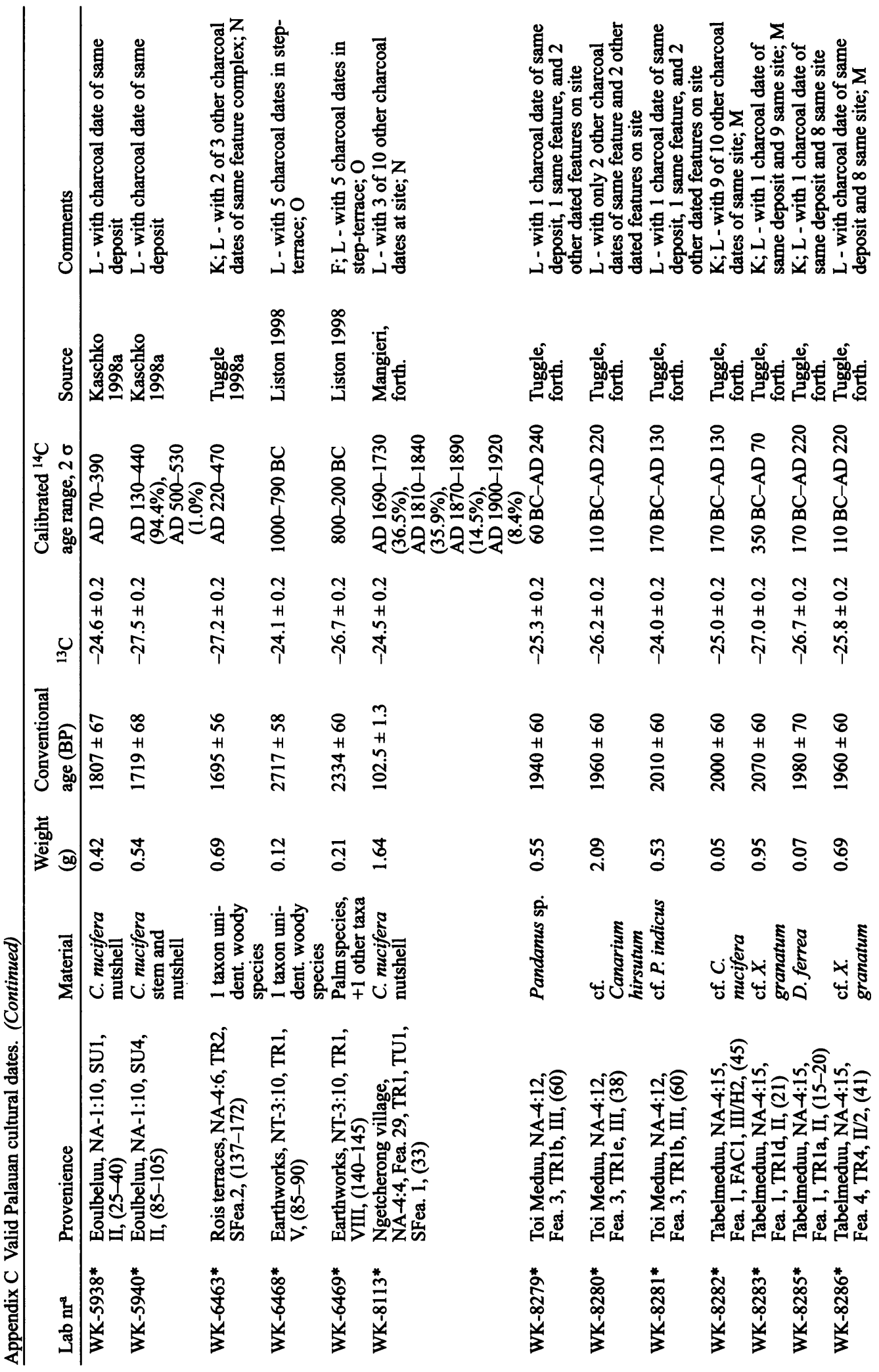




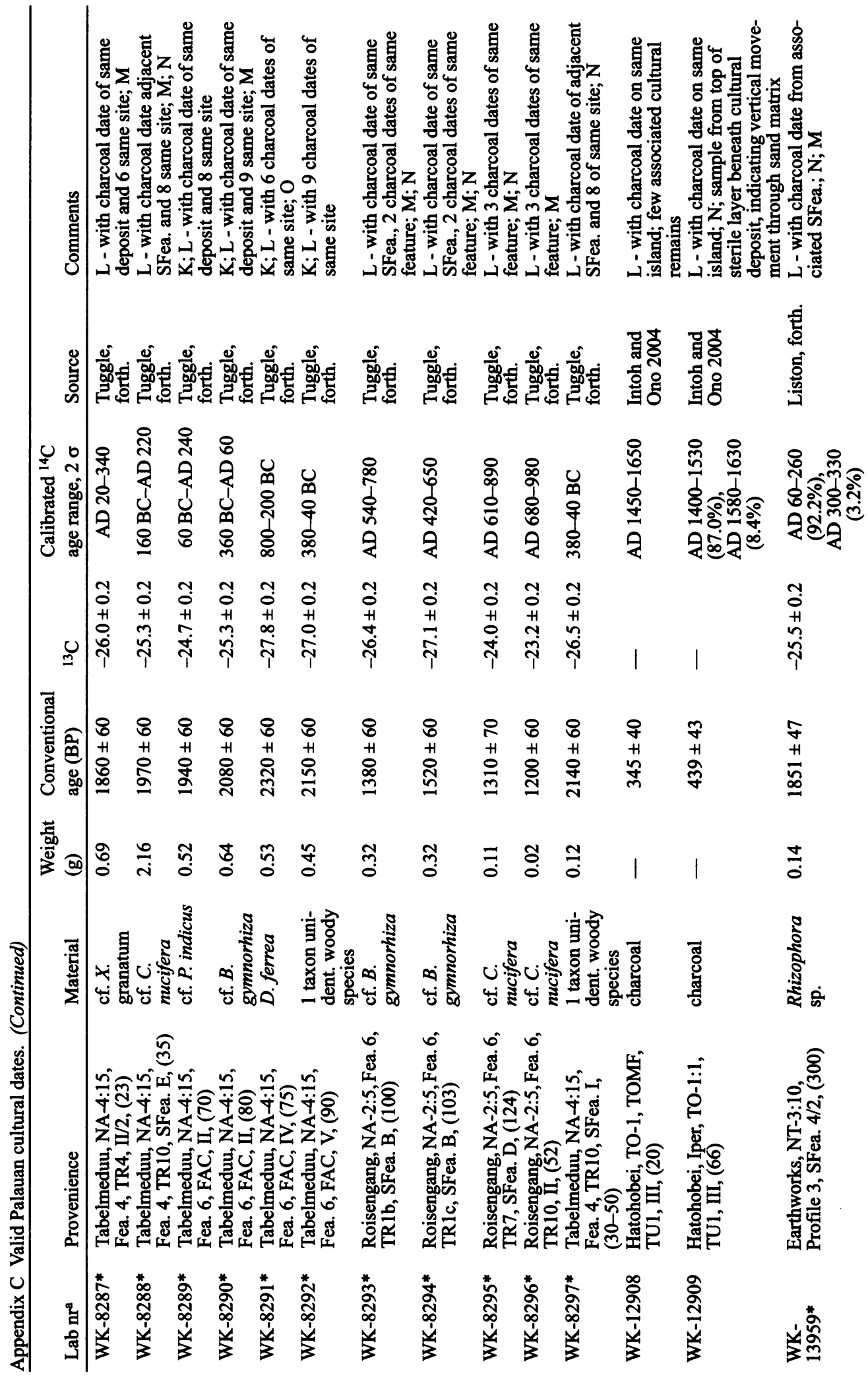




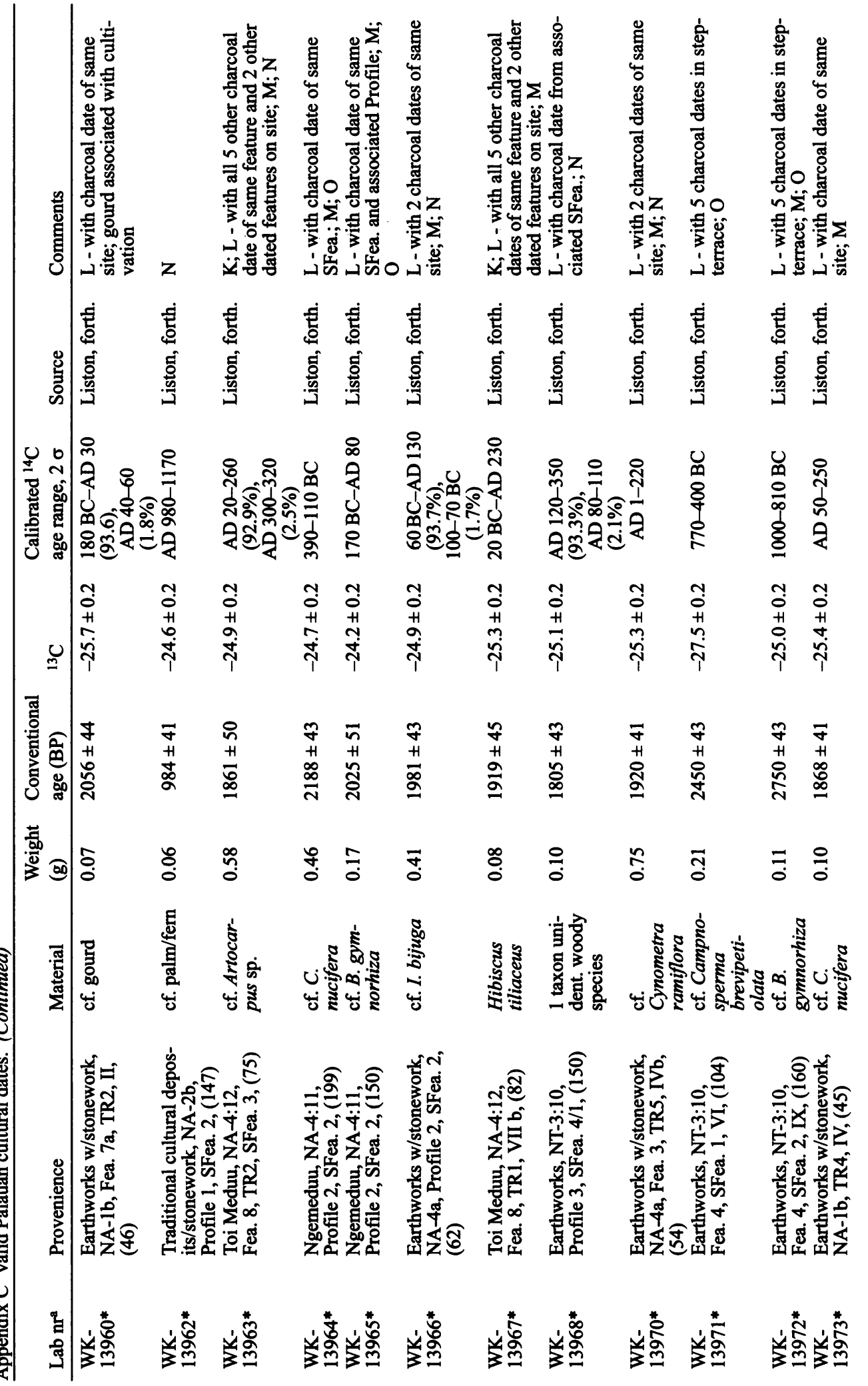




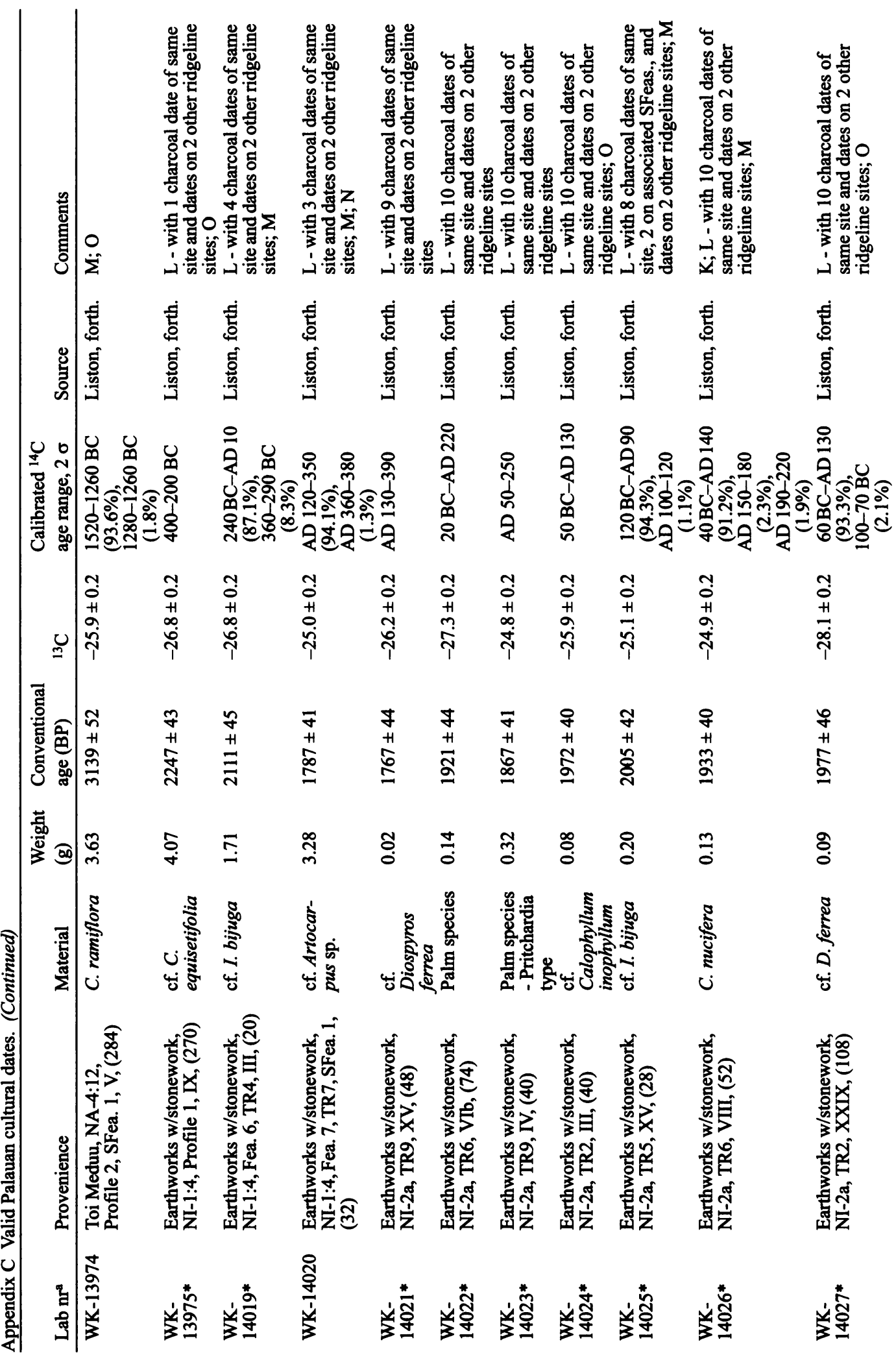




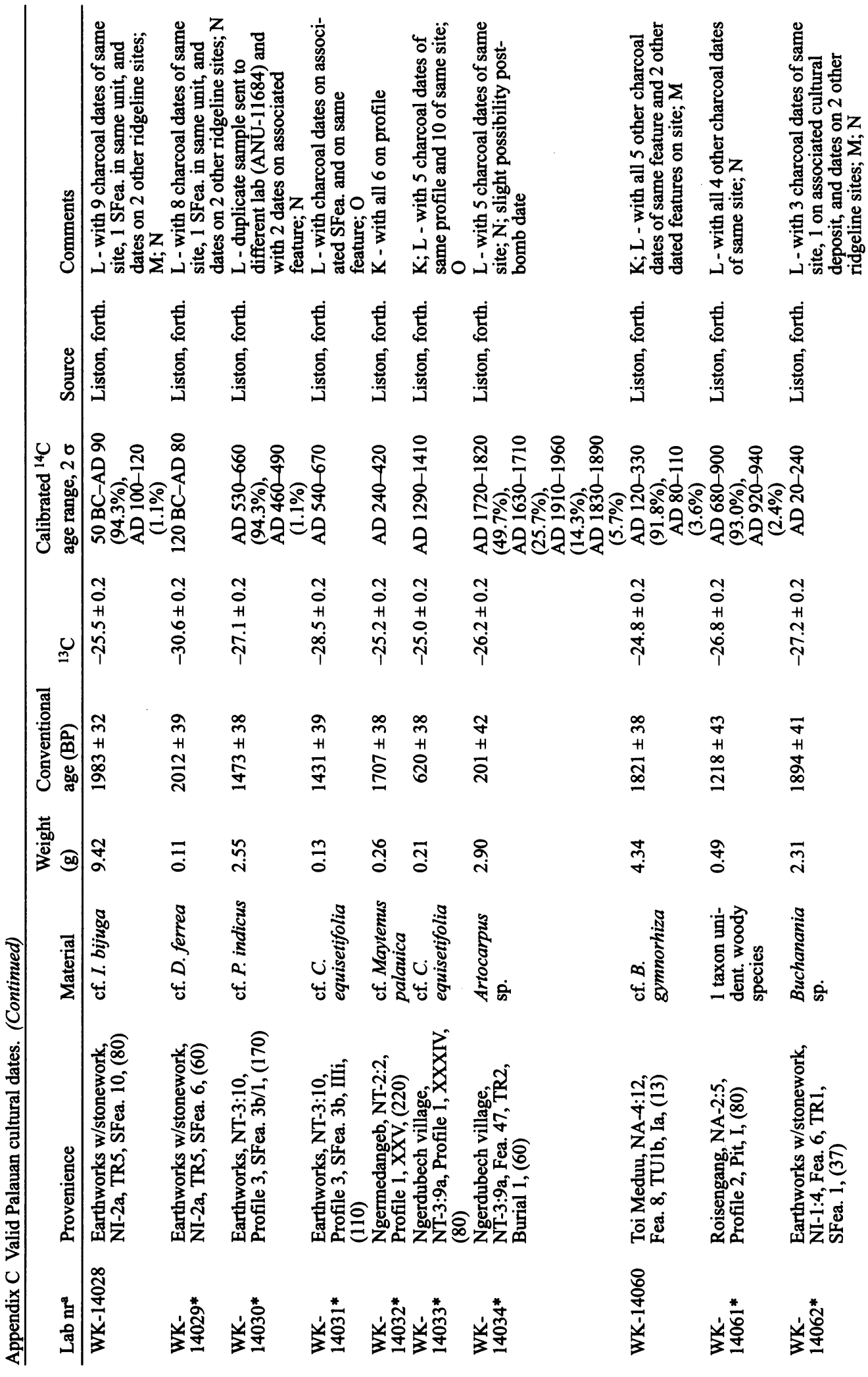




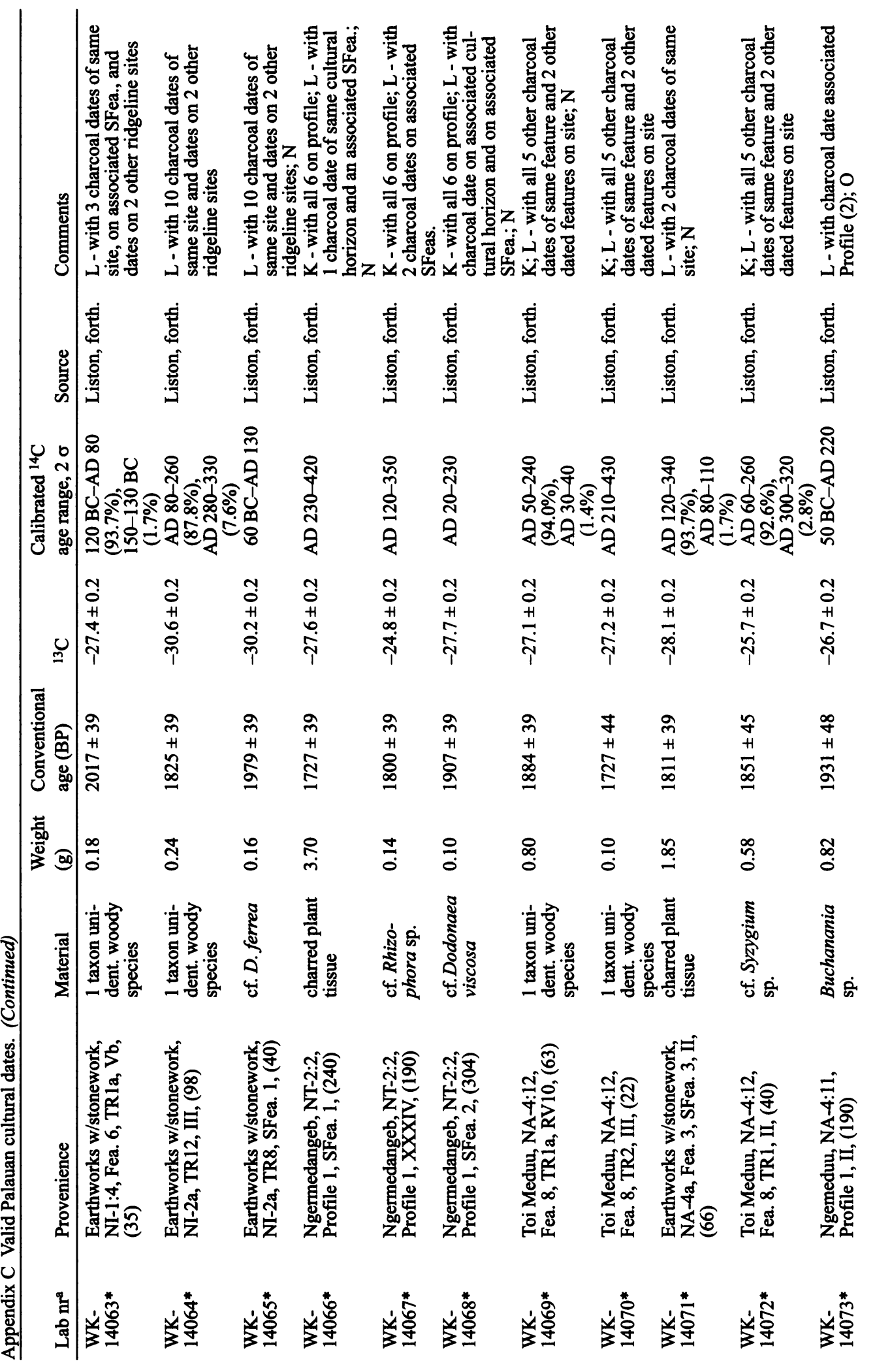




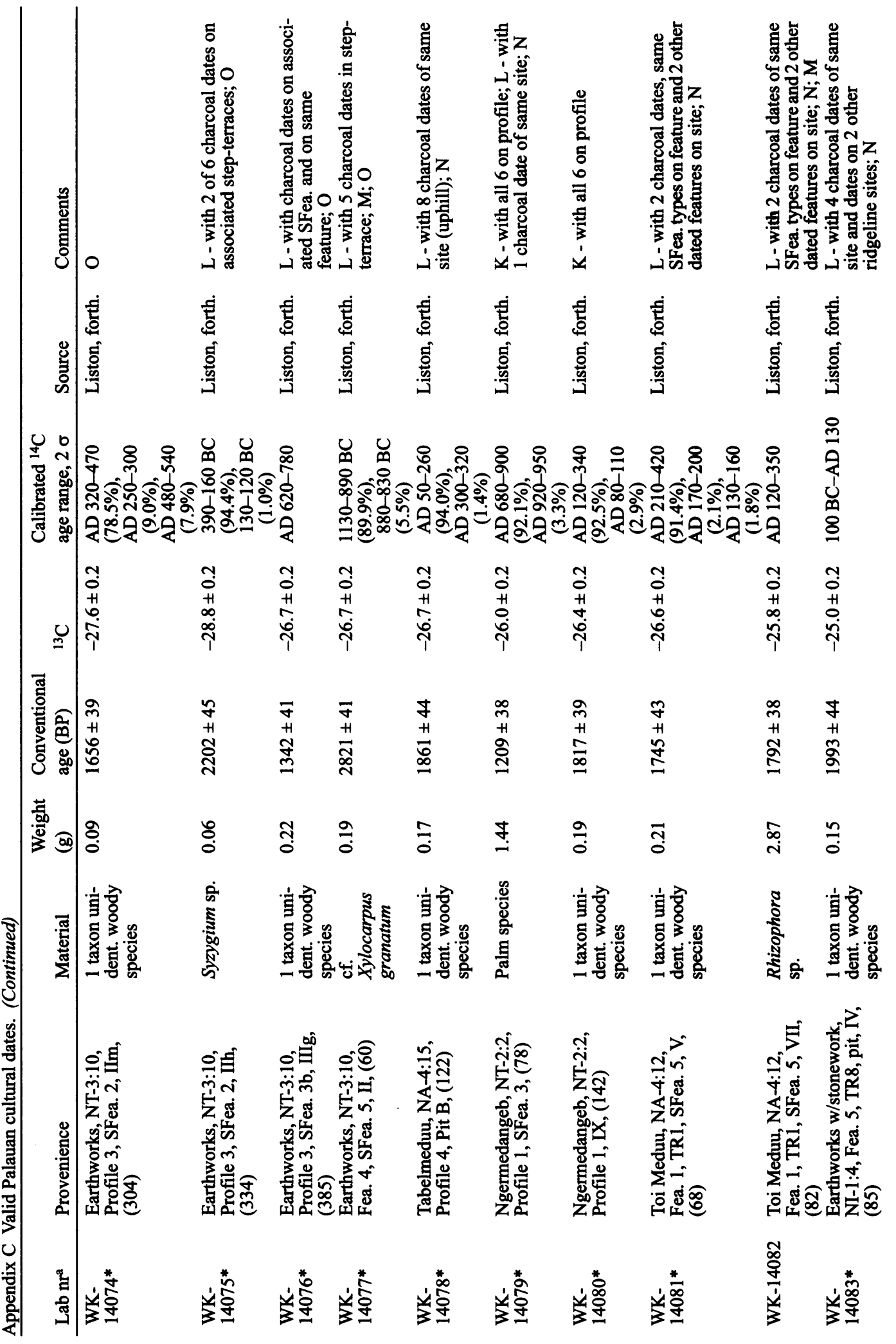




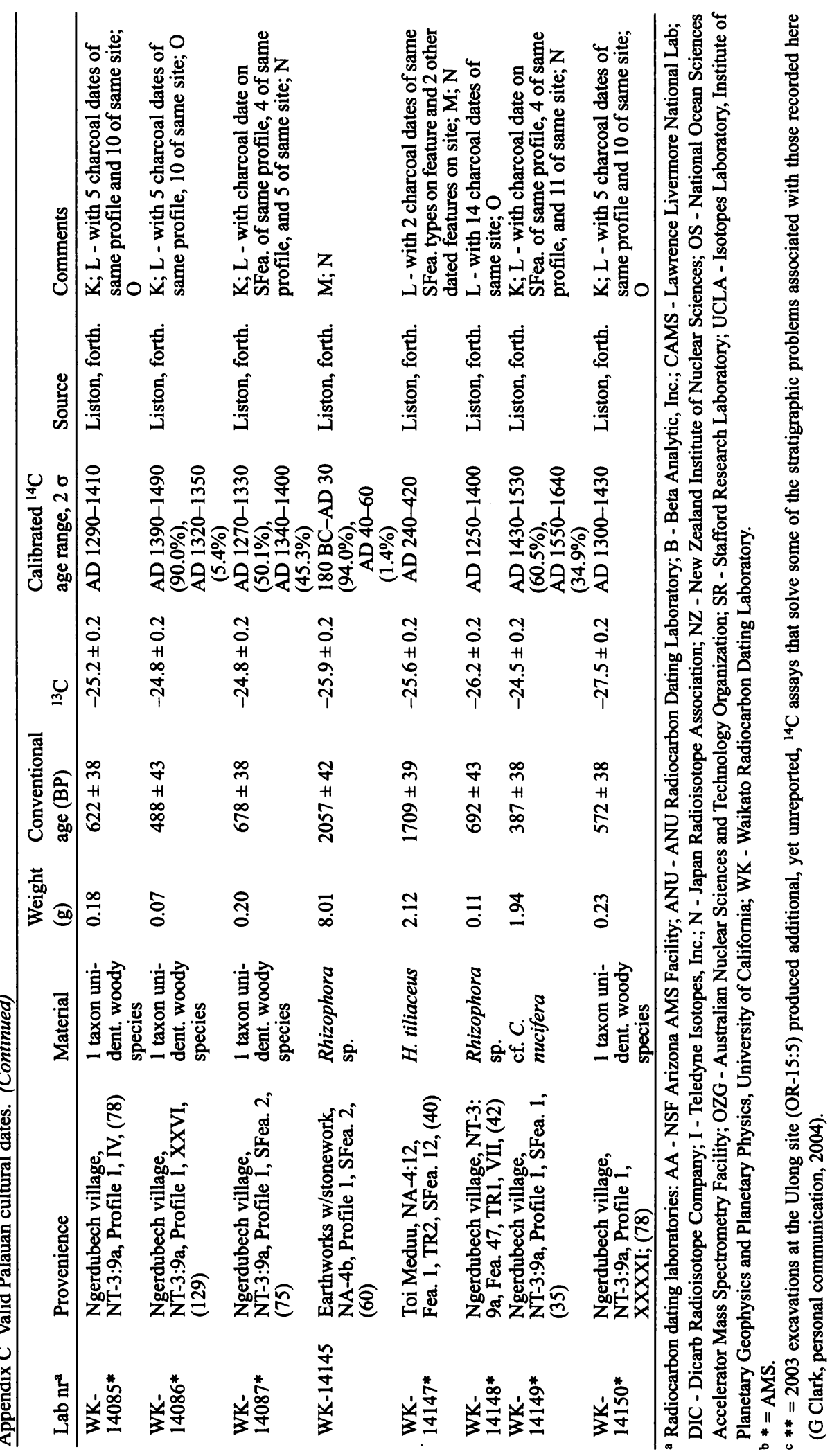




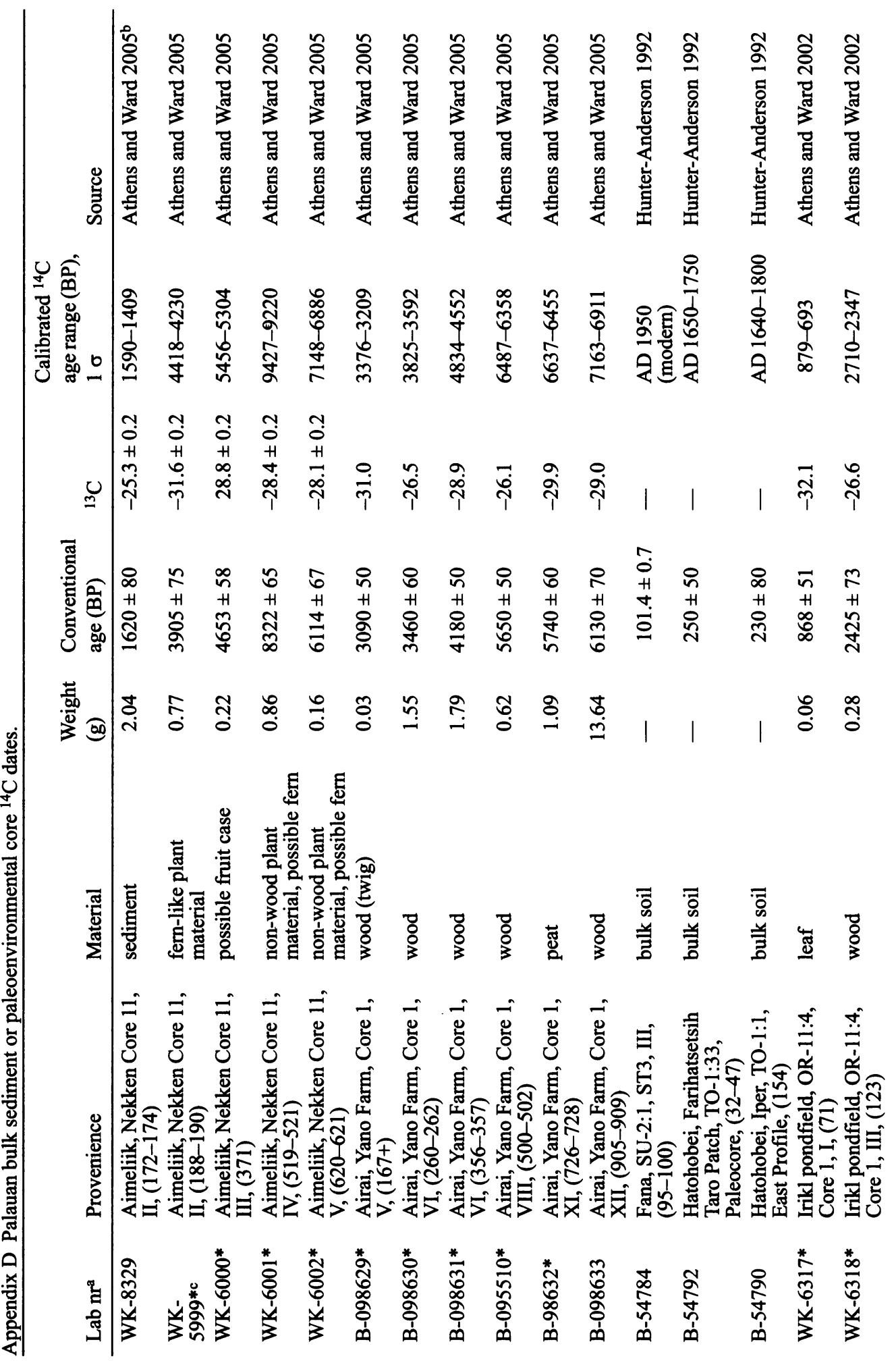




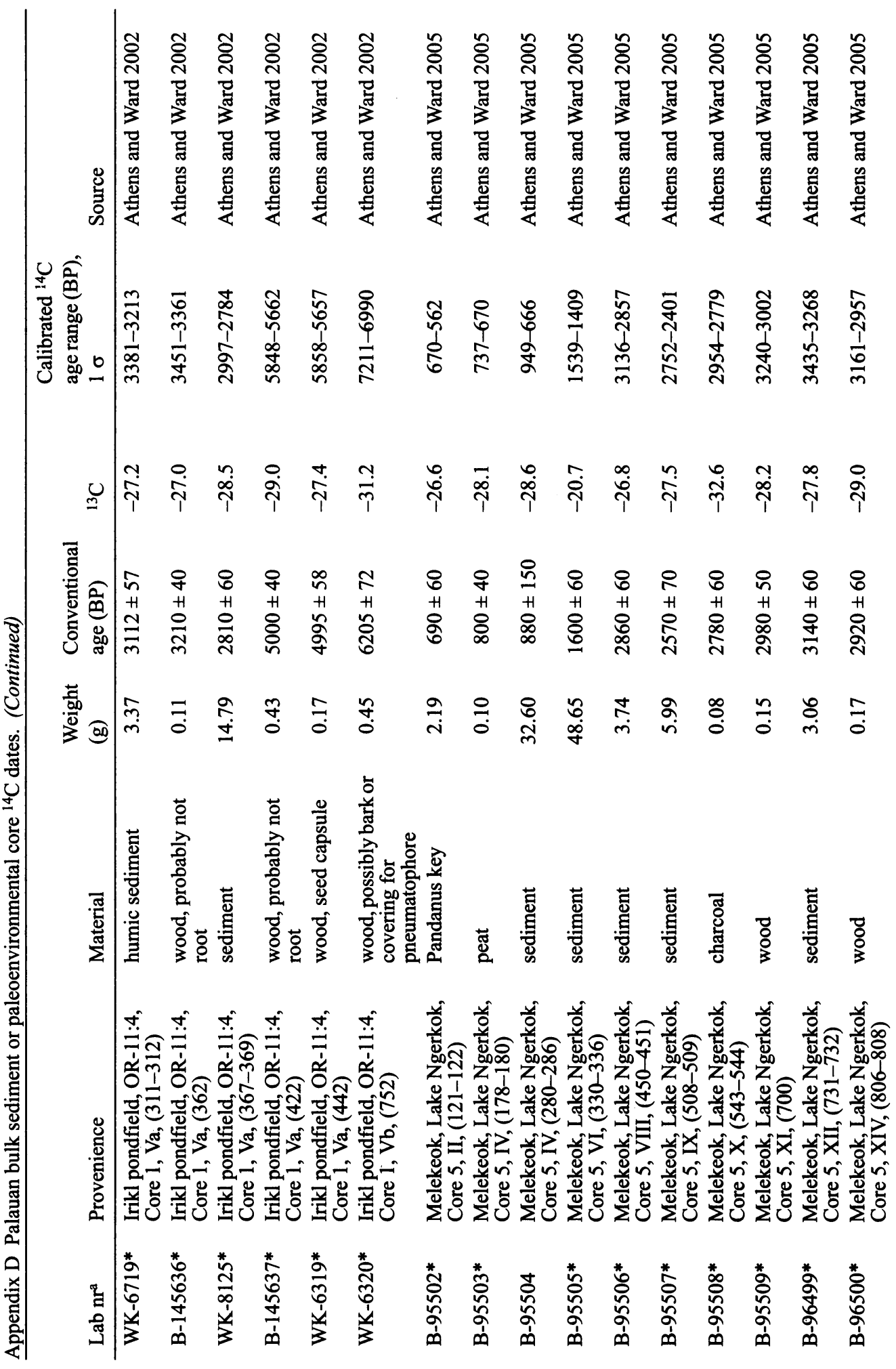




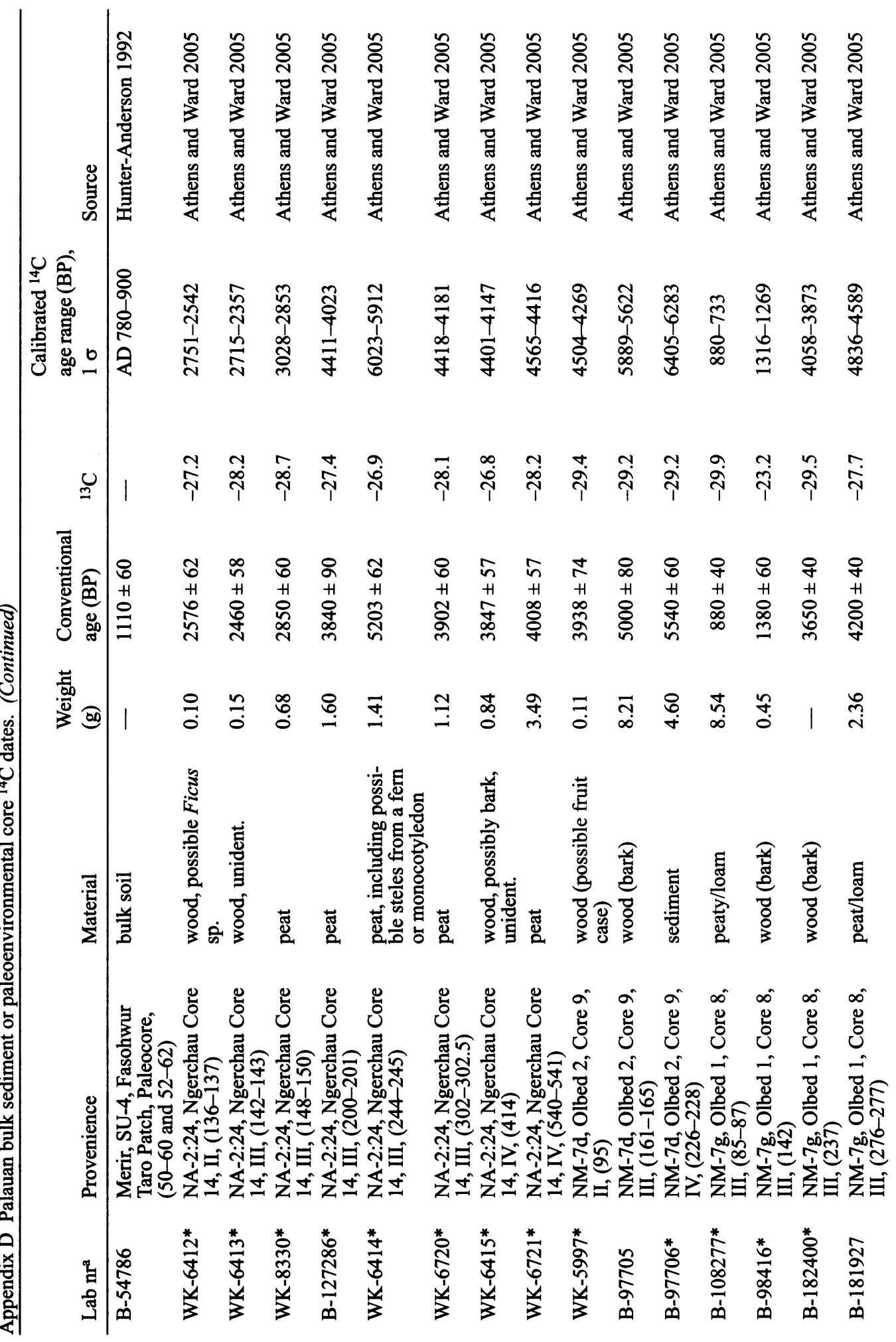




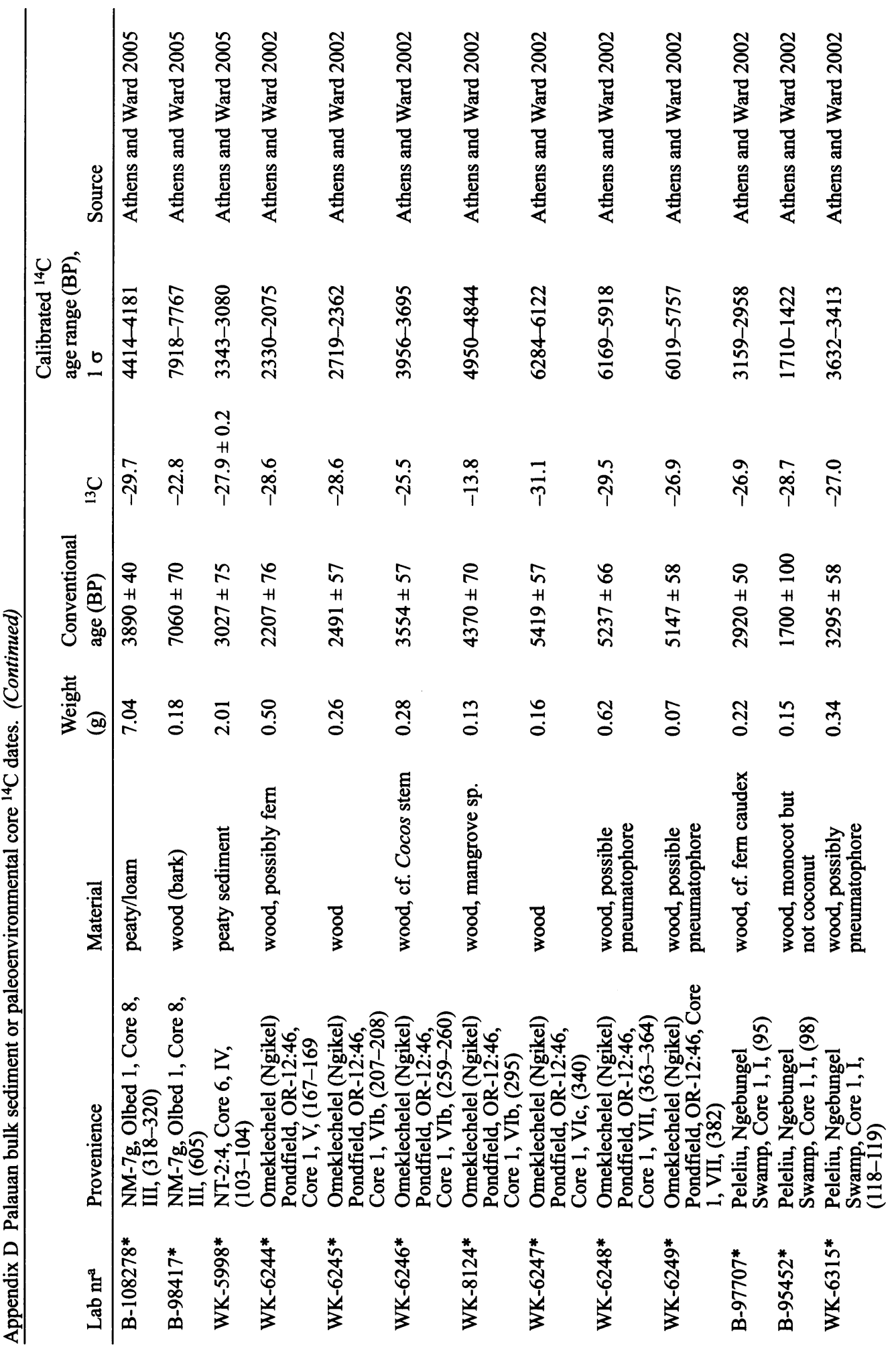




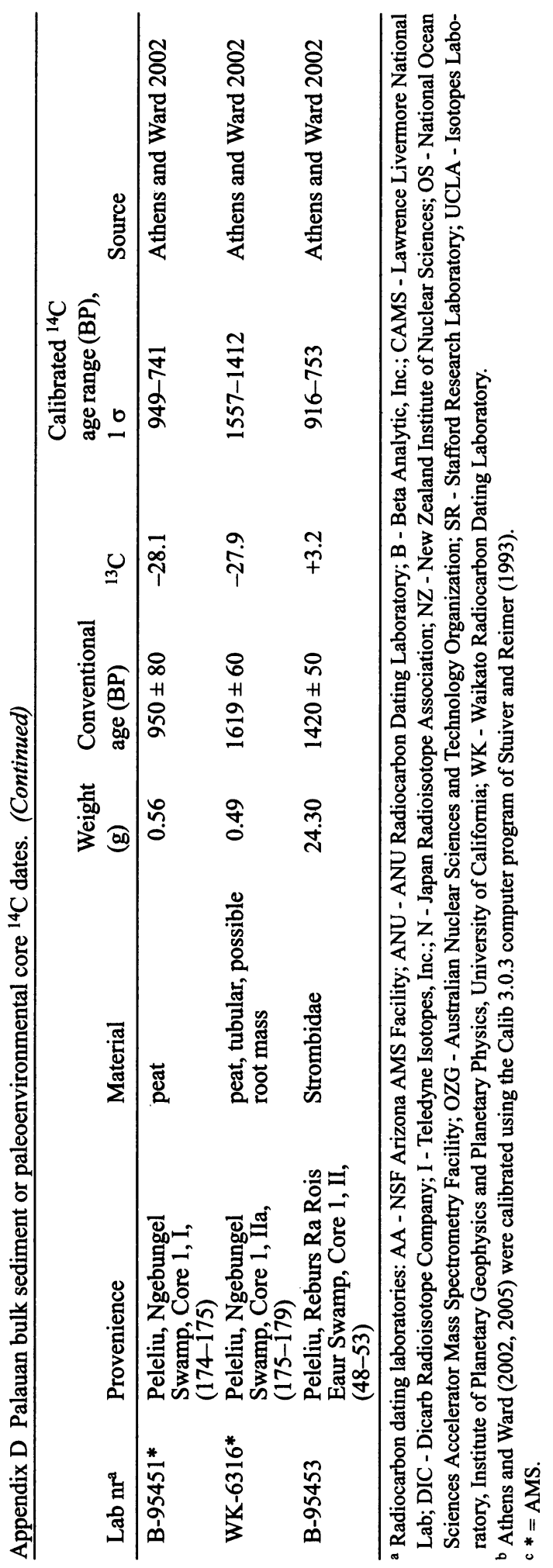

